\title{
"NO OTHER MEANS THAN BY PEN": LETTERS FROM EARLY MODERN ENGLISH NUNS IN EXILE
}

\author{
by
}

Tanyss Sharp, B.A. Honours

A thesis submitted to the Faculty of Graduate and Postdoctoral Affairs in partial fulfillment of the requirements for the degree of

Master of Arts

in

History

Carleton University

Ottawa, Ontario

(C) 2020, Tanyss Sharp 


\begin{abstract}
This thesis explores how early modern English nuns in exile on the European continent purposefully utilized letter writing as a strategy of communication with the outside world. Cut off from their homeland and families by both geographic distance and physical enclosure, letters provided women religious with a medium to ensure their convents' survival and preserve English Catholicism. This critical analysis of nuns' letters reveals the multidimensional nature and intentional construction of their correspondence. Nuns made deliberate epistolary choices. They employed strategic language, utilized flattery and humility, as well as exaggeration and gossip to achieve their objectives. A comparison of individual epistolary experiences demonstrates that letters were vital for maintaining familial and kinship ties, financial and spiritual economies, political engagement, and the transnational diffusion of information.
\end{abstract}




\section{Acknowledgements}

This thesis could not have been completed without the support and encouragement of numerous people.

This thesis was funded in part by SSHRC and OGS, which made it significantly easier to accomplish and allowed for a vital research trip. During my time in England and Belgium the assistance of those at the British Library, National Archives, Bodleian Library, Ushaw College, Ghent State Archives, Archdiocese of Mechelen-Brussels and Bisschoppelijk Archief Bruges was invaluable to my research experience. In particular, I would like to thank Abbot Geoffrey Scott of Douai Abbey for his time and allowing me access to his archive.

I am grateful to the faculty and staff of the Carleton University History Department, and particularly Joan White, for all their assistance throughout this process. I thank my fellow MA's for their friendships, pasta nights, and time spent listening to my musings on nuns. I most of all thank my best friends and family - especially my mom and Ellie - for their constant support and comic relief, as well as eating too many waffles with me in Belgium. Special thanks also to Dr. Jaime Goodrich for her guidance and photocopies of letters that saved me valuable research time.

My sincere gratitude is reserved for my thesis supervisors Dr. Paul Nelles and Dr. Susan Whitney, for their endless guidance and encouragement. 


\section{Table of Contents}

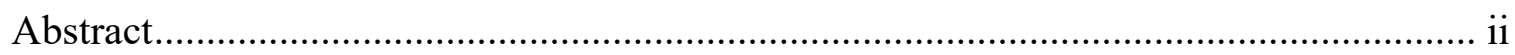

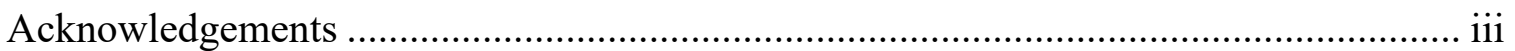

Table of Contents .................................................................................................iv

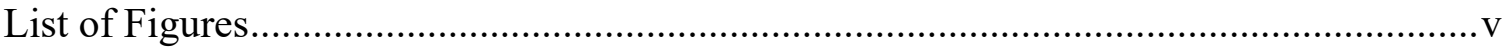

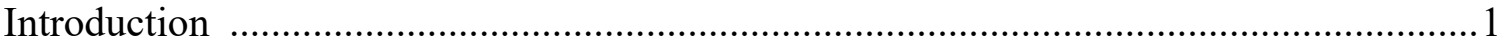

Chapter 1: Letters to Family \& Friends From Exile ...................................................... 31

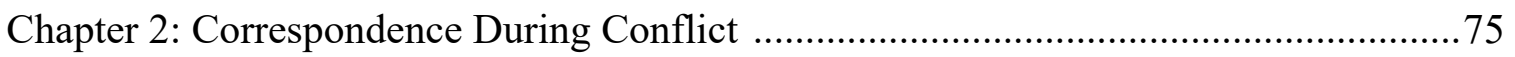

Chapter 3: Political Correspondents, Displomatic Correspondence .............................. 108

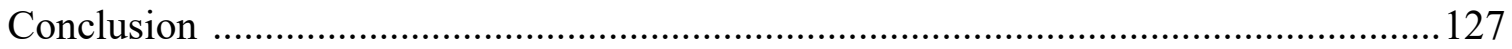

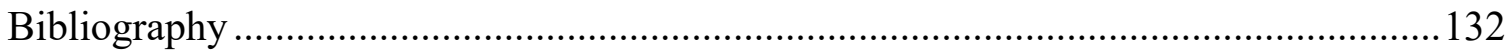




\section{List of Figures}

Figure 1.1 Letter from Winefrid Thimelby to Herbert Aston ....................... 50 


\section{Introduction}

"I can no longer delay conversing with one so near and Dear to me, since I've been frustrated of what I've so many years long'd for; the comfort of your acquaintance of which as all hopes is losst, I've no other means than by pen, $\&$ that can never express $y^{\mathrm{e}}$ fullness of my good wishes, nor $y^{\mathrm{e}}$ tenderness of my affections for you."

This passage originates from a letter written by Arabella Benedicta Caryll, a nun at the English Benedictine convent in Dunkirk in 1734. Her words evoke an attachment to the temporal world seldom expected from women who devoted their lives to the Catholic Church. As this quote demonstrates, women religious maintained significant contact with the secular world after their profession. Because they were enclosed in convents and not allowed to leave without special permission, letters were the only means through which nuns could communicate with the outside world. ${ }^{2}$ As Victoria Van Hyning has stated, "letters had the power to bind and bridge secular and convent spheres. They were the veins through which vital communication...flowed to the convents" and vice versa. ${ }^{3}$ In other words, there was no other means than by pen. Letters provide us insight into the complex ways women religious facilitated, maintained, and exploited transnational social contacts in order to sustain their connections with the world outside their convent walls.

This thesis examines the multifaceted ways English women religious used letters while in exile. Regarding the source material, Nicky Hallett has observed that, "many of the nun's papers have literally been dispersed, 'preserved by chance' or sheer determination in the face of geographic tumult over several centuries." ${ }^{\prime 4}$ Due to the

\footnotetext{
${ }^{1}$ British Library, Family of Caryll Correspondence, Vol. II1. 1732-1739, Additional MS 28 229, fol. 119. The correspondence of Arabella Benedicta Caryll will be discussed in Chapter 1 .

${ }^{2}$ Enclosure will be discussed in more detail in Chapter 1.

${ }^{3}$ Victoria Van Hyning, Convent Autobiography: Early Modern English Nuns in Exile (Oxford: Oxford University Press, 2019), 41.

${ }^{4}$ Nicky Hallett, English Convents in Exile, 1600-1800: Volume 3. Life Writing I, ed. by N. Hallett, E. Perry and V. Van Hyning (London: Pickering \& Chatto, 2012), xi. Most of the time,
} 
fragmented preservation of letters from this period, this thesis will not be constrained to one particular order. Instead, it will focus on the letters of women religious from the Benedictines, Poor Clares, Carmelites, and Augustinians. Largely excluded from this examination are the Dominicans, Bridgettines, Third-Order Franciscans and Sepulchrines due to a lack of available evidence. Discussion of the Mary Ward institute will also be omitted given that these sisters were not enclosed, as such, letter writing would have held a very different meaning and purpose. ${ }^{5}$ Nonetheless, this thesis it will examine the letters of women religious from different orders to show how letter writing served as an invaluable tool of communication.

By comparing individual experiences and uses of epistolary space, we gain a greater understanding of the complex ways in which women religious utilized letters. Comparison exposes common features, including the use of letters to maintain emotional bonds, remain informed and involved in political or worldly affairs, provide spiritual services, sustain economic connections, solicit new recruits, and navigate convent disputes. We will see that although the tone and content of their familial letters differed, Winefrid Thimelby and Mary Caryll were both deeply concerned for their respective family's spiritual well-being as well as the security of their convents. Analysis also

the letters preserved only provide us with one side (usually the nuns') of the conversation, adding a further challenge for those seeking to reconstruct these histories.

${ }^{5}$ For a selection of historical scholarship on Mary Ward and her institute, see Jennifer Cameron, A Dangerous Innovator: Mary Ward (1585-1645) (Strathfield: St Pauls, 2000); Peter Guilday, The English Catholic Refugees on the Continent 1558-1795 (London: Longmans, 1914), 163214; Laurence Lux-Sterrit, "Mary Ward's English Institute: The Apostolate as Self-Affirmation," Recusant History 28, no. 2 (2006): 192-208; Laurence Lux-Sterrit, "Mary Ward's English Institute and Prescribed Female Roles in the Early Modern Church," in Gender, Catholicism and Spirituality, ed. by Laurence Lux-Sterrit and Carmen M. Mangion (Basingstoke: Palgrave Macmillan, 2011), 83-98; Henriette Peters, Mary Ward: A World in Contemplation, trans. H. Butterworth (Leominster: Gracewing Publishing, 1994). 
reveals the diverse and intentional ways that women religious constructed correspondence. Nuns made deliberate epistolary choices. They employed strategic deferential language and utilized flattery and humility, as well as exaggeration and gossip. But letters were not always a positive tool. In some circumstances, especially during times of conflict, letters could exacerbate a situation and harm a convent in the long term. This thesis will demonstrate that letters were never one dimensional. Ultimately, letter writing was a powerful tool for women religious. Without letters, they would not have been able to engage actively and regularly with the outside world.

\section{Literature Review}

The study of English nuns in exile exists at a crossroads of historical inquiry. Examinations of this topic are interdisciplinary, incorporating religious history, women's and gender history, and transnational history. Because English convents existed as spaces that were simultaneously "decidedly English" and "emphatically Tridentine and European," they fit uneasily into larger histories of English religion and continental convents. ${ }^{6}$ English religious scholarship has largely been oriented around the Protestant reformation and has been anti-Catholic. ${ }^{7}$ In his 2012 book, for instance, Eric Ives presented Protestants killed under Mary I as martyrs, but Catholics executed under

\footnotetext{
${ }^{6}$ Caroline Bowden, James E. Kelly, and Michael C. Questier, "Introduction," in The English Convents in Exile, 1600-1800, ed. by C. Bowden and J. E. Kelly (Burlington, VT: Ashgate, 2013), 2.

${ }^{7}$ For the epitome of this stance, see Arthur G. Dickens, The English Reformation (London: Collins, 1964). However, more scholars have begun to reassess this view of Protestant hegemony. See Christopher Highley, Catholics Writing the Nation in Early Modern Britain and Ireland (Oxford: Oxford University Press, 2008), and Raymond Tumbleson, Catholicism in the English Protestant Imagination: Nationalism, Religion, and Literature, 1660-1745 (Cambridge:

Cambridge University Press, 2009).
} 
Elizabeth I as traitors. ${ }^{8}$ Catholic marginality has also meant that studies of English Catholicism and recusancy have tended to exist in isolation from the rest of English history. ${ }^{9}$ For these reasons, perhaps, English women religious were largely omitted as subjects of historical analysis before the twenty-first century. Today, the idea that English women religious simply vanished after the dissolution has been entirely disproven and these women have begun to be re-integrated into English religious history. As well, the history of European nuns, including how they were affected by the reforms of the Council of Trent, has been a thriving field of inquiry for many years. Nonetheless, these studies have rarely considered English conventual experience. ${ }^{10}$ This thesis brings together these diverse scholarly conversations.

${ }^{8}$ Eric Ives, The Reformation Experience: Living Through the Turbulent 16th Century (Oxford: Lion, 2012), 221-233, 256.

${ }^{9}$ See for example, John Bossy, The English Catholic Community 1570-1850 (London: Darton, Longman and Todd, 1975). An important exception to this trend is Alexandra Walsham, "Translating Trent? English Catholicism and the Counter Reformation," Historical Research 78, no. 201 (2005): 288-310.

${ }^{10}$ One exception to this trend is Silvia Evengelisti, Nuns: A History of Convent Life 1450-1700 (Oxford: Oxford University Press, 2007) which briefly touches on the English convent experience, 37, 58, 212-224. For a selection of sources on European convents and reform movements see Barbara B. Diefendorf, From Penitence to Charity: Pious Women and the Catholic Reformation in Paris (Oxford: Oxford University Press, 2004); Doris Gottemoeller, "Religious Life for Women: From Enclosure to Immersion," in From Trent to Vatican II: Historical and Theological Investigations, ed. by R. Bulman and F. Parella (Oxford: Oxford University Press, 2006), 228-240; Craig Harline, "Actives and Contemplatives: the Female Religious of the Low Countries Before and After Trent," Catholic Historical Review 81, no. 4 (1995): 541-567; Helen Hills, Invisible City: The Architecture of Devotion in Seventeenth Century Neapolitan Convents (Oxford: Oxford University Press, 2004); Mary Laven, Virgins of Venice: Enclosed Lives and Broken Vows in the Renaissance Convent (London: Viking Penguin, 2002); Jo Ann McNamara, Sisters in Arms: Catholic Nuns through Two Millennia (Cambridge, MA: Harvard University Press, 1996); Francesca Medioli, “An Unequal Law: The Enforcement of Clausura Before and After the Council of Trent," in Women in Renaissance and Early Modern Europe, ed. by Christine E. Meek (Dublin: Four Courts Press, 2000), 136-152; Ulrike Strasser, State of Virginity: Gender, Religion, and Politics in an Early Modern Catholic State (Ann Arbor: University of Michigan Press, 2004); Gabriella Zarri, "Gender, Religious Institutions and Social Discipline: The Reform of the Regulars," in Gender and Society in Renaissance Italy, ed. by Judith C. Brown and Robert C. Davis (London: Longman, 1998). 
Scholarship on English nuns in exile has developed rapidly over the last two decades. While many scholars have utilized letters as evidence in their studies of English nuns in exile, few have critically analyzed how letters functioned as a communication tool used by women religious. In her article on conflict within the English Benedictine convent at Brussels, for example, Jaime Goodrich used the letters produced by the Brussels nuns to discuss the cultural and gender politics at play within the convent. ${ }^{11}$ While this study is notable for being the first in-depth examination of the Brussels controversy, it downplays the fact that it was letters that allowed this conflict to escalate, and exist at the scale it did.

The pioneering work of Claire Walker has been instrumental in changing the narrative of English women religious. Her book, Gender and Politics in Early Modern Europe: English Convents in France and the Low Countries, remains one of the few monographs to date which examines the creation, organization, and maintenance of English convents on the continent. ${ }^{12}$ Walker has also produced numerous articles on English nuns, that discuss convent management, politics, and exile experience, in which letters are utilized as historical evidence. ${ }^{13}$ Walker's most explicit discussion of convent

\footnotetext{
${ }^{11}$ Jaime Goodrich, "Authority, Gender, and Monastic Piety: Controversies at the English Benedictine Convent in Brussels, 1620-1623," British Catholic History 33, no. 1 (2016): 91-114.

${ }^{12}$ Claire Walker, Gender and Politics in Early Modern Europe: English Convents in France and the Low Countries (New York: Palgrave Macmillan, 2003)

${ }^{13}$ These include, Claire Walker, "Combining Martha and Mary: Gender and Work in Seventeenth-Century English Cloisters," The Sixteenth Century Journal 30, no. 2 (1999): 397 418; "Prayer, Patronage, and Political Conspiracy: English Nuns and the Restoration," The Historical Journal 43, no. 1 (2000): 1-23; "Doe not supose me a well mortifyed Nun dead to the world": Letter-writing in Early Modern English Convents," in Early Modern Women's LetterWriting, 1450-1700, ed. by J. Daybell (Basingstoke: Palgrave Macmillan, 2001), 159-176; "Loyal and Dutiful Subjects: English Nuns and Stuart Politics," in Women and Politics in Early Modern England, 1450-1700, ed. by J. Daybell (Burlington, VT: Ashgate, 2004), 228-242; "Spiritual Property: The English Benedictine Nuns of Cambrai and the Dispute over the Baker Manuscripts," in Women, Property and the Letters of the Law in Early Modern England, ed. by N.E. Wright, M.W. Ferguson, and A. R. Buck (Toronto: University of Toronto Press, 2004), 237
} 
letter writing can be found in a 2001 article. ${ }^{14}$ In this article, Walker discusses the letter writing of multiple women religious and organizes their letters into three categories, monastic business, patronage, and family news. Although Walker remarks that, "inevitably these areas overlap," by relying on these categorizations, and discounting the 'overlap', her article overlooks the polyvalent nature of monastic letters. ${ }^{15}$ As we will see, a single letter could intertwine multiple concerns, for instance, carefully blending family news and monastic business interests. Therefore this article can be regarded more as a starting point than the final word on the subject. This thesis builds upon Walker's work by exploring letter writing in more depth, exploring common epistolary patterns and emphasizing the strategic construction of, and diverse purposes behind, letters.

Caroline Bowden has similarly been influential in shaping the new wave of historical investigation. Bowden has written numerous articles on English nuns, covering topics such as convent education, identity, writing and cultural exchange. ${ }^{16}$ One of

255; "Recusants, Daughters and Sisters in Christ: English Nuns and their Communities in the Seventeenth Century," in Women, Identities and Communities in Early Modern Europe, ed. by Stephanie Tarbin and Susan Broomhall (Aldershot: Ashgate, 2008), 61-76; "Securing Souls or Telling Tales? The Politics of Cloistered Life in an English Convent," in Female Monasticism in Early Modern Europe: an Interdisciplinary View, ed. by Cordula van Wyhe (Burlington, VT: Ashgate, 2008), 227-244; "Crumbs of News: Early Modern English Nuns and Royalist Intelligence Networks," Journal of Medieval and Early Modern Studies 42, no. 3 (2012): 635655.

${ }^{14}$ Walker, "Doe not supose me a well mortifyed Nun dead to the world'," 159-176.

${ }^{15}$ Walker, "Doe not supose me a well mortifyed Nun dead to the world"," 160.

${ }^{16}$ See Caroline Bowden, "The Abbess and Mrs. Brown: Lady Mary Knatchbull and Royalist Politics in Flanders in the Late 1650s", Recusant History, 24 (1999): 288-208; "“For the Glory of God': A Study of the Education of English Catholic Women in Convents in Flanders and France in the First Half of the Seventeenth Century," Paedagogica Historica 35 (1999): 77-95; "Community Space and Cultural Transmission: Formation and Schooling in English Enclosed Convents in the Seventeenth Century." History of Education 34, no. 4 (2005): 365-386; "Collecting the Lives of Early Modern Women Religious: Obituary Writing and the Development of Collective Memory and Corporate Identity," Women's History Review 19, no. 1 (2010): 7-20; "Patronage and Practice: Assessing the Significance of the English Convents as Cultural Centres in Flanders in the Seventeenth Century," English Studies 92, no. 5 (2011): 483-495; "Missing Members: Selection and Governance in the English Convents in Exile," in The English Convents 
Bowden's most significant articles to deal with letter writing examines how Mary Knatchbull, abbess at Ghent, was able to use letters to navigate both the convent and the royal court. ${ }^{17}$ Yet the article serves to highlight the scholarly trend of presenting letter writers in isolation, rather than assessing them comparatively. It is only by taking a comparative approach that we can uncover larger patterns of communication.

This thesis aims to highlight the multidimensional nature of letter writing through a critical examination of the experiences of multiple letter writers. It also strives to contribute to existing scholarship by offering an analysis of the previously unexamined correspondence of the Hagan Sisters. ${ }^{18}$ By making letters the primary subject of study, the thesis emphasizes that letters were a flexible, polyvalent tool. Letters not only facilitated contact with the outside world, but were the fundamental instrument that both ensured convent survival and the preservation of English Catholicism.

Taking a step back, one of the most significant developments in the field of English nuns has been the creation of the "Who Were the Nuns" prosopographical database in 2013, co-founded by Caroline Bowden and James E. Kelly. This online database identified 24 religious institutions and nearly 4000 women who left England between

in Exile, 1600-1800, ed. by C. Bowden and J. E. Kelly (Burlington, VT: Ashgate, 2013), 53-68; "Building Libraries in Exile: The English Convents and Their Book Collections in the Seventeenth Century," British Catholic History 32, no. 3 (2015): 383-389.

${ }^{17}$ Caroline Bowden, "The Abbess and Mrs. Brown," 288-208.

${ }^{18}$ This correspondence has been reproduced in Volume 6 of English Convents in Exile but with only a brief (one page) contextualization provided by Caroline Bowden. The letters themselves have not been critically analyzed. See "Connections Between Europe and America Before Independence," in English Convents in Exile, 1600-1800: Volume 6: The Convents and the Outside World, ed. by Carmen M. Mangion, Michael Questier, Emma Major and Caroline Bowden (London: Pickering \& Chatto, 2012), 143-153; and "Letter of Mary Louisa Hagan," in English Convents in Exile, 1600-1800: Volume 6. The Convents and the Outside World, ed. by Carmen M. Mangion Michael Questier, Emma Major and Caroline Bowden, (London: Pickering \& Chatto, 2012), 279-282. 
1600 and 1800 to form or join English convents in exile. ${ }^{19}$ Because it is freely available online, the site has allowed historians to make connections, both genealogical and kinship based, that would have otherwise remained hidden. This project has also produced a collection of essays and six volumes of edited and transcribed primary documents. ${ }^{20}$ The volumes' diverse content ranges from convent management and contact with the outside world to spirituality and life writing. They have become invaluable to any historian in this field.

Other scholars have contributed extensively to the field in the last decade. The recent book, English Benedictine Nuns in Exile in the Seventeenth Century, by Laurence Lux-Sterritt, explores the tension between lived experience and prescribed rules in English Benedictine convents. This monograph is significant for how it examines spirituality, emotions, relationships among sisters and the necessity of maintaining outside connections. ${ }^{21}$ Bronagh Ann McShane has recently produced an insightful article that uses network analysis to provide a new lens with which to interpret the circulation of

\footnotetext{
19 'Who Were the Nuns? A Prosopographical Study of the English Convents in Exile, 16001800', [hereafter WWTN] http://wwtn.history.qmul.ac.uk/. The project, supported by the AHRC at Queen Mary University ran from 2008 and 2013, identified 3900 nuns and 22 English convents on the continent (as well as the Mary Ward institute, and one convent founded in America). Beyond this, it used statistical analysis to explore convent communities in greater detail. The project uncovered a wealth of archival information about women religious in exile and led to an upsurge in scholarship, covering a variety of angles, on early modern English convents abroad.

${ }^{20}$ For this thesis the most relevant volumes include English Convents in Exile, 1600-1800: Volume 1. History Writing, ed. by C. Bowden (London: Pickering \& Chatto, 2012); English Convents in Exile, 1600-1800: Volume 3. Life Writing I, ed. by N. Hallett, E. Perry and V. Van Hyning (London: Pickering \& Chatto, 2012); and English Convents in Exile, 1600-1800: Volume 6: The Convents and the Outside World, ed. by C. M. Mangion, M. Questier, E. Major and C. Bowden (London: Pickering \& Chatto, 2012).

${ }^{21}$ Laurence Lux-Sterritt, English Benedictine Nuns in Exile in the Seventeenth Century: Living Spirituality (Manchester: Manchester University Press, 2017); see also Laurence Lux-Sterritt, and Carmen M. Mangion, Gender, Catholicism and Spirituality: Women and the Roman Catholic Church in Britain and Europe, 1200-1900 (Basingstoke: Palgrave Macmillan, 2011), for a useful collection of articles on the history of women religious.
} 
letters during the Brussels Benedictine controversies. ${ }^{22}$ The work of Jaime Goodrich on the Benedictines has provided an important literary perspective on the writing of women religious and has reshaped how we conceive of the boundary between the public and private sphere. ${ }^{23}$ Victoria Van Hyning's recent book, Convent Autobiography: Early Modern English Nuns in Exile, is the first book to be devoted entirely to English nuns' autobiographical writing. Beyond this, it provides a valuable examination of literary and personal letter writing activity, with Chapter One specifically focuses on the epistolary activity of the Aston-Thimelby family. ${ }^{24}$ Nicky Hallett has published extensively on the life writing of English nuns, particularly the Carmelites. ${ }^{25}$ James E. Kelly, who co-created the "Who Were the Nuns" database, has also produced significant articles on English Catholic exile identity, community and transnational exchange networks. ${ }^{26}$

\footnotetext{
${ }^{22}$ Bronagh Ann McShane, "Visualising the Reception and Circulation of Early Modern Nuns' Letters," Journal of Historical Network Research 2 (2018): 1-25.

${ }^{23}$ See Jaime Goodrich, "Thomas More and Margaret More Roper: A Case for Rethinking Women's Participation in the Early Modern Public Sphere," The Sixteenth Century Journal 39, no. 4 (2008): 1021-1040; "A Poor Clare's Legacy: Catherine Magdalen Evelyn and New Directions in Early Modern Women's Literary History," English Literary Renaissance 46, no. 1 (2016): 3-28; "Authority, Gender, and Monastic Piety: Controversies at the English Benedictine Convent in Brussels, 1620-1623," British Catholic History 33, no. 1 (2016): 91-114. For other discussions on the breakdown of the public vs. private sphere see: Janet L. Nelson, "The Problematic in the Private," Social History 15, no. 3 (1990), 355-364; Joan Kelly-Gadol, "The Social Relation of the Sexes: Methodological Implications of Women's History," in Feminism and Methodology, ed. by S. Harding (Bloomington: Indiana University Press, 1987), 15-28.

${ }^{24}$ Van Hyning, Convent Autobiography, 1. Van Hyning has also edited sections of English Convents in Exile, 1600-1800: Volume 3. Life Writing I that have been particularly useful to this thesis.

${ }^{25}$ Nicky Hallett, Lives of Spirit: English Carmelite Self-Writing of the Early Modern Period (Aldershot: Ashgate, 2007); "Paradise Postponed: The Nationhood of Nuns in the 1670s," in Religion, Culture and the National Community in the 1670s, ed by T. Claydon and T. Corns (Cardiff: University of Wales Press, 2011), 10-34.

${ }^{26}$ James E. Kelly, "Jesuit News Networks and Catholic Identity: The Letters of John Thorpe to the English Carmelite Nuns at Lierre, 1769-89," in Jesuit Intellectual and Physical Exchange Between England and Mainland Europe, c.1580-1789, ed. by J. E. Kelly and H. Thomas, (Leiden: Brill, 2018), 337-360; "Creating an English Catholic Identity: Relics, Martyrs and English Women Religious in Counter-Reformation Europe," in Early Modern English Catholicism: Identity, Memory, and Counter-Reformation, c. 1570-1800, ed. by J.E. Kelly and S. Royal (Leiden: Brill, 2017), 41-59. James Kelly's newest book, English Convents in Catholic
} 
We would be remiss if we overlooked the larger literature on women and religion of this period. Caroline Walker Bynum's innovative work on female piety, with its emphasis on acknowledging individual voices and the importance of context, has been particularly influential in bringing attention to the role of women in medieval Europe. ${ }^{27}$ Historians such as Natalie Zemon Davis, Merry Weisner-Hanks and Miri Rubin have contributed greatly to our understanding of the relationship between women and religion in the medieval and early modern period. ${ }^{28}$ Other scholars, such as, Helen Hills, Mary Laven, Barbara Diefendorf, Elizabeth Rapley, and Ulrike Strasser, have examined women religious in ways that illuminate how they were not a homogenous group, but rather had diverse experiences of religion and convent life. ${ }^{29}$

The development of women's religious history has been furthered by the development of women's and gender history. While women's history has been important

Europe, C.1600-1800 (Cambridge: Cambridge University Press, 2020), was not available for reference at the time of writing.

${ }^{27}$ For a selection of Caroline Walker Bynum's work see: Holy Feast and Holy Fast: The Religious Significance of Food to Medieval Women (Berkeley: University of California Press, 1987); Fragmentation and Redemption: Essays on Gender and the Human Body in Medieval Religion (New York: Zone Books, 1991); The Resurrection of the Body in Western Christianity, 200-1336 (New York: Columbia University Press, 1996); Metamorphosis and Identity (New York: Zone Books, 2001); ““Crowned with Many Crowns” Nuns and their Statues in LateMedieval Wienhausen," Catholic Historical Review 101, no. 1 (2015): 18-40.

${ }^{28}$ For a selection of this scholarship, see Natalie Zemon Davis, Women on the Margins: Three Seventeenth-Century Lives (Cambridge, MA.: Harvard University Press, 1995); Merry WiesnerHanks, Convents Confront the Reformation: Catholic and Protestant Nuns in Germany (Milwaukee: Marquette University Press, 1996); "Women's Response to the Reformation," in The German People and the Reformation, ed. R. Po-Chia Hisa (Ithaca, N.Y.: Cornell University Press, 1988), 148-171; Women and Gender in Early Modern Europe, 2nd ed. (New York: Cambridge University Press, 2000); Miri Rubin, Mother of God: A History of the Virgin Mary (London: Allen Lane, 2009).

${ }^{29}$ For a selection of this scholarship see Barbara Diefendorf, From Penitence to Charity; Helen Hills, Invisible City; Mary Laven, Virgins of Venice; Elizabeth Rapley, The Dévotes: Women and the Church in Seventeenth-Century France (Montréal: McGill Queen's University Press, 1993); Ulrike Strasser, State of Virginity; "Early Modern Nuns and the Feminist Politics of Religion," The Journal of Religion 84, no. 4 (2004): 529-554. 
in uncovering "experiences and voices suppressed by history," it has also highlighted that it is not enough to simply "add women" into our analysis. ${ }^{30}$ As Patricia Crawford has argued, the experience of early modern women was influenced by many factors, and we must recognize that there was never any universal female experience of religion, or even of convent life. ${ }^{31}$ The tendency toward generalizing or universalizing experience is one of the main critiques that Caroline Walker Bynum had of feminist history in the 1970s and 1980s. The goal of her book, Holy Feast and Holy Fast, was to make women the subject, rather than the object, of historical analysis, and illustrate their agency and ability to exert control and manipulate their environments. Her work critiqued feminist scholarship of the time that "tended to concentrate on the negative stereotyping of women's sexuality and on women's lack of worldly power...because...[those were] issues...of such pressing modern concern." ${ }^{32}$ Similarly, as Joan W. Scott argued in her influential 1986 article on gender, attempts to uncover a collective female experience lead to a "ahistorical, if not essentialist, notion of women." ${ }^{33}$ Yet this does not mean that we cannot discover patterns

\footnotetext{
${ }^{30}$ Karen Gevirtz, "Recent Developments in 17th and 18th-Century English Catholic Studies: Studies in English Catholicism," Literature Compass 12, no. 2 (2015): 51. See also Caroline Walker Bynum, Metamorphosis and Identity; Bynum, "Why Paradox? The Contradictions of My Life as a Scholar," The Catholic Historical Review 98, no. 3 (2012): 433-455; Natalie Zemon Davis, “'Women's History' in Transition: The European Case," Feminist Studies 3, no. 3/4 (1976): 83-103; Kelly, Women, History \& Theory: The Essays of Joan Kelly (Chicago: University of Chicago Press, 1984).

${ }^{31}$ For a selection of Patricia Crawford's work see Crawford, "From the Woman's View: PreIndustrial England 1550-1750," in Exploring Women's Past: Essays in Social History, ed. by Patricia Crawford (Sydney: Allen \& Urwin, 1985), 49-85; Women and Religion in England, 1500-1720 (New York: Routledge, 1993); Sara Heller Mendelson and Patricia Crawford, Women in Early Modern England, 1550-1720 (Oxford and New York: Clarendon Press, 1998).

${ }_{32}^{32}$ Bynum, Holy Feast and Holy Fast, 29.

${ }^{33}$ Joan W. Scott, "Gender: A Useful Category of Historical Analysis," The American Historical Review 91, no. 5 (1986): 1065. Scott also argued that while uncovering female experience is important, there is a bias to view some experiences as more valuable than others or focus only on one group of women - such as white, middle class women - as if their experience represents all women. See more in Scott, "Evidence of Experience," Critical Inquiry 17, no.4 (1991), 773-797.
} 
or similarities in female experience. As Walker Bynum wrote, historians must be "slow to project or to appropriate, quick to assume there is significance, slow to generalize about it." ${ }^{34}$ As this thesis will demonstrate, we should be slow to assume that nuns utilized letters uniformly and for similar reasons. Instead, by analyzing comparatively, we can uncover similarities and differences in women religious' epistolary experiences.

The development of feminist histories was often slow to affect religious studies. As a largely male dominated institution, the Catholic church was often portrayed as "an entirely disempowering" space for women. ${ }^{35}$ Women religious were seen as passive recipients of a patriarchal Christianity that encouraged "piety, purity, submissiveness and domesticity." 36 However, including women in examinations of English Catholicism has allowed historians to gain a more nuanced understanding of the interrelationship between women religious and the Church. In fact, recent scholarship has revealed that Christianity, and especially monasticism, offered women a valuable opportunity to exert power and autonomy and to build community solidarity. ${ }^{37}$ This thesis will build on this historical trajectory by showing how letters provided women religious a multidimensional tool that allowed them to subvert the normative ideal of nuns as meek and submissive and to wield influence and control.

\footnotetext{
${ }^{34}$ Bynum, Metamorphosis and Identity, 74.

${ }^{35}$ Sue Morgan, "Introduction. Women, Religion and Feminism: Past Present and Future Perspectives," in Women, Religion and Feminism in Britain, 1750-1900, ed. by S. Morgan (Basingstoke: Palgrave Macmillan, 2002), 9.

${ }^{36}$ Barbara Welter, "The Cult of True Womanhood: 1820-1860," American Quarterly 18, no. 2 (1966): 152. Further, as Diane Willen has argued, the previous prevailing view of gender and religion focused on Christianity as, "a misogynist tradition... [which] emphasized women's weakness and potential for corruption." See Diane Willen "Religion and the Construction of the Feminine," in A Companion to Early Modern Women's Writing, edited by A. Pacheco (Oxford: Blackwell, 2002), 23.

${ }^{37}$ Morgan, "Introduction," 10; Elizabeth A. Clark, "Women, Gender, and the Study of Christian History," Church History 70, no. 3 (2001) 401-402.
} 
Recent scholarship on transnational history also offers insight into analysis of the letter writing of women religious in exile. As Marie Louise Coolahan has argued, "a community of women religious is always transnational: the women belong firstly to the order, and then to their nation." "38 Thinking about nuns as 'transnational actors' allows us to consider their influence on a much broader scale than if they were simply confined to convents. Letters exemplify the nuns' transnational nature, since letters allowed them to reach larger audiences than they would have had without this medium. Therefore, this thesis seeks to highlight the multifaceted, and transnational, nature of women religious' letter writing and uncover common themes through individual practices.

\section{The Letter as Genre}

Scholarship on early modern women's writing has developed rapidly in the last few decades, from both a literary and historical perspective. The emergence of literary history has allowed scholars to counter the idea that there were virtually no women writers before 1700, and the few who did write were regarded as "'rare and eccentric creatures'." 39 Yet, as Jaime Goodrich has argued, "the feminist recovery of writings by early modern Englishwomen during the 1980s and 1990s almost completely overlooked the texts produced by the continental convents for Englishwomen." ${ }^{40}$ In her discussion of women's religious writing, Micheline White has reasoned that these texts have generally not been of interest to feminist scholars since they do not "openly criticize the patriarchal

\footnotetext{
${ }^{38}$ Marie Louise Coolahan, “Identity Politics and Nuns' Writing," Women's Writing 14, no. 2 (2007): 307.

${ }^{39}$ Anita Pacheco, "Introduction," in A Companion to Early Modern Women's Writing, ed. by A. Pacheco (Oxford: Blackwell, 2002), xvi; Margaret J. M. Ezell, Writing Women's Literary History (Baltimore: Johns Hopkins University Press, 1993), 42.

${ }^{40}$ Jaime Goodrich, "Translating Lady Mary Percy: Authorship and Authority among the Brussels Benedictines," in The English Convents in Exile, 1600-1800: Communities, Culture and Identity, ed. by C. Bowden and J. E. Kelly, (Burlington VT: Ashgate, 2013), 109.
} 
understanding of male-female relations or dwell at length on marriage, female education, female authorship, maternity, sexuality, or female ecclesiastical authority." ${ }^{41}$ Moreover, as Anita Pacheco has argued:

"A narrow view of literature as the traditional canonical genres of poetry, drama and fiction, [and the]... preoccupation with publication and commercialism led feminist literary historians to overlook or ignore the significant numbers of women... who wrote for an audience (though not for profit) in a wide variety of genres: letters, diaries, prophecies, advice books, religious treatises." 42

This 'narrow view' has meant that, while letters often serve as a source of historical evidence, they have not necessarily been investigated as part of women's literary production. Expanding our understanding of literature to include non-canonical writing has allowed, as Karen Gevirtz has argued, for the "recovery of individuals and groups who have been left out of scholars' understanding of English Catholicism until now." ${ }^{43}$ In this vein, letters allow insight into the experience of women religious not captured by other written works.

To date, studies of nuns' literary production have generally included examinations of convent autobiographies, chronicles, and spiritual treaties, but not correspondence. Yet the analysis of epistolary activity and space shows that the process of letter creation is more intricate than it might first appear. James How defines epistolary spaces as "spaces of connection, providing permanent and seemingly unbreakable links between people and places." ${ }^{44}$ As Julie D. Campbell and Anne R. Larson argue, the most fundamental

\footnotetext{
${ }^{41}$ Micheline White, "Introduction: Women, Religious Communities, Prose Genres, and Textual Production," in English Women, Religion, and Textual Production, 1500-1625, ed. by M. White (Burlington, VT: Ashgate, 2011), 1.

${ }^{42}$ Anita Pacheco, "Introduction," xvi.

${ }^{43}$ Gevirtz, "Recent Developments in 17th and 18th-Century English Catholic Studies," 48.

${ }^{44}$ James How, Epistolary Spaces: English Letter Writing from the Foundation of the Post Office to Richardson's Clarissa (Aldershot: Ashgate, 2003), 4.
} 
purpose of letters was to facilitate communication and connectedness between correspondents, who were separated, for whatever reason, by great distance ${ }^{45}$ In their 2009 volume on women and transnational letters, Campbell and Larson emphasize the need to take an international, interdisciplinary and comparative approach to women's writing. ${ }^{46}$ However, only one essay in this volume deals with women religious, and it follows the previously mentioned historical trend of focusing on the continental convent experience ${ }^{47}$ The epistolary activity of English women religious is once again entirely absent.

As a source for women's history, letters are particularly rich. They are, as James Daybell has argued, social documents that have much to tell us about women's social interaction. ${ }^{48}$ They also provide precious "examples of female self-expression." ${ }^{49}$ As such, letters provide an "alternative viewpoint... different from both male voiced prescriptive literatures as well as other 'autobiographical' sources." ${ }^{\prime 50}$ Letters, therefore, provide a unique medium with which to capture the experience of women religious and their connections with the outside world. Yet, Elizabeth Goldsmith has argued, women's letters have often been misread. ${ }^{51}$ In other words, there has been a tendency to assume

\footnotetext{
${ }^{45}$ Julie D. Campbell and Anne R. Larson, "Introduction," in Early Modern Women and Transnational Communities of Letters, ed. by J. D. Campbell and A. R. Larson (Burlington, VT: Ashgate, 2009), 11.

${ }^{46}$ Campbell and Larson, "Introduction,"1-2. Campbell and Larson describe their methodology as in line with Peter Herman's "new inclusivity", 5.

${ }^{47}$ This essay is: Meredith K. Ray, "Letters and Lace: Arcangela Tarabotti and Convent Culture in Seicento Venice," in Early Modern Women and Transnational Communities of Letters, ed. by J. D. Campbell and A. R. Larson (Burlington, VT: Ashgate, 2009), 45-73.

${ }^{48}$ James Daybell, “Introduction," in Early Modern Women's Letter-Writing, 1450-1700, ed. by J. Daybell (Basingstoke: Palgrave Macmillan, 2001), 3.

${ }^{49}$ Daybell, "Introduction," 3.

${ }^{50}$ Daybell, "Introduction," 4.

${ }^{51}$ Elizabeth C. Goldsmith, "Introduction," in Writing the Female Voice: Essays on Epistolary

Literature, ed. by E. C. Goldsmith (London: Pinter, 1989), x.
} 
that letters act as "transparent expressions of the private self," rather than as carefully constructed forms of communication..$^{52}$ As James How aptly points out, "letter writers never believe themselves to be howling pathetically into a void, expecting no reply and no satisfaction of their desires." ${ }^{53}$ It is, therefore, essential to understand the purpose behind letters, and their intended outcomes, rather than accepting their content at face value. This is especially true when attempting to assess affection or devotion in letters. As Jane Couchman has argued, "expressions of devotion which may seem 'sincere' from our point of view may owe as much to form and persuasive strategy as they do to personal emotion. ${ }^{" 54}$ Letters were not simply private, personal, writings, but public ones possessing explicit goals and audiences. This thesis will demonstrate that the letters of English nuns were written with clear personal motivations and utilized diverse, yet strategic, epistolary techniques to achieve their objectives.

\section{Setting the Stage}

When English monasteries were dissolved over the course of the sixteenth century, thousands of Catholic women were affected. But women religious did not simply disappear; instead, they went into exile. In terms of sheer numbers, there were an estimated 2,000 nuns within 142 nunneries in England during the 1530's. All would be dissolved by Henry VIII in $1539 .{ }^{55}$ After this, many Catholic women, whether formerly

\footnotetext{
${ }^{52}$ Goldsmith, "Introduction," $\mathrm{x}$.

${ }^{53}$ How, Epistolary Spaces, 3.

${ }^{54}$ Jane Couchman, "Resisting Henry IV: Catherine de Bourbon and her brother," in Sibling Relations and Gender in the Early Modern World: Sisters, Brothers and Others, ed. by N. J. Miller and N. Yavneh (Aldershot: Ashgate, 2006), 65.

${ }^{55}$ G. W. Bernard, "The Dissolution of the Monasteries," History 96, no. 4 (2011): 390. Patricia Crawford states that by the time of the dissolution in 1536 the number of nuns had dropped to 1,600, Women and Religion in England, 22. All monasteries were officially dissolved by the Act for the Dissolution of the Greater Monasteries, passed in 1539, Knowles, Bare Ruined Choirs, 242; Dickens and Carr, The Reformation in England, 105.
} 
nuns or not, left England and travelled to the continent. One of the only known congregations of nuns to survive the dissolution of the monasteries in England were the Bridgettines of Syon Abbey, who eventually ended up in Lisbon. ${ }^{56}$ For the most part, however, English women initially joined continental religious houses. The group of 28 English women who joined the Flemish Augustinian cloister at Louvain is just one example of Catholic women who joined continental convents in order to preserve their religious identity.$^{57}$ But those who joined continental houses were often hampered by "cultural and spiritual difficulties" stemming from issues as diverse as a lack of common language, an unfamiliar diet, or differing labour expectations. ${ }^{58}$ To counter this, English nuns created their own convents on the continent.

In 1598, the first distinctly English convent was founded in Brussels by Mary Percy, and it was quickly followed by others that endured until the late eighteenth century. ${ }^{59}$ Over time, English convents were established across France and the Low Countries by the Augustinians, Benedictines, Bridgettines, Carmelites, Dominicans, Franciscans, Poor Clares and Sepulchrines. ${ }^{60}$ By the end of the seventeenth century, fifteen enclosed English convents had been formed in Flanders alone, and 1300 women professed. ${ }^{61}$ The final English convent, a Carmelite house in Antwerp, was established in

\footnotetext{
${ }^{56}$ Caroline Bowden, "General Introduction," in English Convents in Exile, 1600-1800: Volume 1. History Writing, ed. by C. Bowden (London: Pickering \& Chatto, 2012), xi; Claire Walker, Gender and Politics in Early Modern Europe, 13.

${ }^{57}$ Bowden, "General Introduction," xi.

${ }^{58}$ Walker, Gender and Politics in Early Modern Europe, 13-14.

${ }^{59}$ Bowden, "Patronage and Practice," 484.

${ }^{60}$ For a complete list of the convents and brief histories, see the WWTN website under 'Convent Notes': http://wwtn.history.qmul.ac.uk/about/convent-notes/index.html [Accessed Oct 5 2019]

${ }^{61}$ Bowden, "Patronage and Practice," 484.
} 
1678, proving that the desire for monasticism did not diminish among English Catholic women. $^{62}$

The choice of location for English convents was often strategic. For instance, Mary Percy chose Brussels because Flanders was controlled by the deeply religious Spanish Archduke Albert and his wife Isabella. ${ }^{63}$ Northern France and the Spanish Netherlands were also ideal locations because of their proximity to the English coast. ${ }^{64}$ As per the decrees of the Council of Trent, convents had to be built within city walls, English convents were therefore established in urban centers, often with dense populations. ${ }^{65}$ Despite their location, English convents had to be self-reliant and could not draw on local resources (both for finances and members), so as not to compete with their continental counterparts. ${ }^{66}$ As we will see, letters became essential for maintaining financial security.

Many English convents also became linked through the creation of 'daughter houses,' which occurred when a new convent was founded as an offshoot of another. For example, the Benedictine convents of Boulogne (1652), Dunkirk (1662), and Ypres (1665) were all daughter houses of the Ghent convent ${ }^{67}$ Convents were also linked by family networks, which saw sisters, aunts, cousins and more distant relatives all become

\footnotetext{
${ }^{62}$ Bowden, "Collecting the Lives of Early Modern Women Religious," 8.

${ }^{63}$ Bowden, "General Introduction," xi.

${ }^{64}$ Lux-Sterritt, English Benedictine Nuns in Exile in the Seventeenth Century, 6.

${ }^{65}$ Bowden, "General Introduction," xii.

${ }^{66}$ Bowden, "General Introduction," xii-xiii, xvi. Notably, religious houses were exempt from paying taxes which increased local anxiety about the creation, and upkeep, of English monasteries, Lux-Sterritt, English Benedictine Nuns in Exile in the Seventeenth Century, 2.

${ }^{67}$ Bowden, "General Introduction," xxx-xxxi; Lux-Sterritt, English Benedictine Nuns in Exile in the Seventeenth Century, xvii-xx. The Ghent convent was also an offshoot of the original Brussels convent, but its creation (as we will see in Chapter Two) was acrimonious.
} 
nuns. ${ }^{68}$ Letters allowed connections outside the convent to be preserved, which in turn facilitated additional convent recruitment.

\section{Identity in Exile}

For English Catholics, and nuns more specifically, identity was shaped by multiple factors. In this period, English Catholic identity largely revolved around the need "to cope with the exercise of royal power wielded in an unprecedented, unexpected manner." ${ }^{99}$ But Catholic emigration came at a high cost and was not undertaken lightly. Under the reign of Elizabeth I, for example, the English government outlawed the practice of sending children to the continent to be educated. This had been one of the leading reasons for young girls to enter convents. ${ }^{70}$ In 1571, Elizabeth I further proclaimed that “subjects leaving England without the queen's licence, and not returning within six months, were to forfeit their goods, chattels and the profits of their lands." ${ }^{.71}$ The penalties against Catholics only increased further under the reigns of James I and Charles I during the seventeenth century. ${ }^{72}$ Nevertheless, for those who chose to leave England, "exile was internalized to the point where it became a key element in how its members defined themselves." ${ }^{, 73}$ One may even consider the enclosure of nuns in convents as an additional "internal exile." 74

\footnotetext{
${ }^{68}$ Bowden, "General Introduction," xv.

${ }^{69}$ Brad S. Gregory, "Situating Early Modern English Catholicism," in Early Modern English Catholicism, ed. by J. Kelly and S. Royal (Boston: Routledge, 2017), 17.

${ }^{70}$ Bowden, "Community Space and Cultural Transmission," 365; Lux-Sterritt, English Benedictine Nuns in Exile in the Seventeenth Century, 5. For more on convent education see Bowden, "For the Glory of God'," 77-95.

${ }^{71}$ Lux-Sterritt, English Benedictine Nuns in Exile in the Seventeenth Century, 5.

${ }^{72}$ Bowden, "Community Space and Cultural Transmission," 365.

${ }^{73}$ Nicholas Terpstra, Religious Refugees in the Early Modern World: An Alternative History of the Reformation (Cambridge: Cambridge University Press, 2015), 4.

${ }^{74}$ Terpstra, Religious Refugees in the Early Modern World, 5.
} 
It is important to note here that English nuns consequently existed in a liminal space. They were defined by their religious identity, which was "a clearly...oppositional status" given the situation in England, but also by their national identity, from which they were, theoretically, cut off. ${ }^{75}$ In order to truly understand why English monasteries were created, we have to recognize that English women religious did not see their exile as permanent. The explicit goal of the convents was to preserve the Catholic faith among English women. ${ }^{76}$ In fact, the first English Benedictine convent in Brussels predated its male equivalent on the continent by eight years, which shows that women religious were spearheading the preservation of English monasticism. ${ }^{77}$ As Liesbeth Corens has argued, these convents intentionally maintained their English identity and "refused to assimilate" because they were awaiting "the recatholisising of England, and their ensuing remigration. ${ }^{78}$ Even English Protestant travellers who visited the convents generally depicted them as "isles of familiar culture in the middle of a strange continent." ${ }^{\text {"79 }}$ In other words, English convents symbolized the survival and preservation of English Catholicism.

\section{Convent Finances, Patronage and Education}

Though only one out of the 23 English convents eventually failed (in 1786), the houses were plagued by financial insecurity. ${ }^{80}$ Consequently, letter writing was an

\footnotetext{
${ }^{75}$ Bowden, "Patronage and Practice," 485.

${ }^{76}$ Bowden, "General Introduction," xvi.

${ }^{77}$ Bowden, "General Introduction," xiii.

${ }^{78}$ Liesbeth Corens, "Catholic Nuns and English Identities. English Protestant Travellers on the English Convents in the Low Countries, 1660-1730," Recusant History 30, no. 3 (2011): 445 446.

${ }^{79}$ Corens, "Catholic Nuns and English Identities," 452.

${ }^{80}$ Bowden, "General Introduction," xxi. The only English convent to close during this period was the Pontoise Benedictines in 1786 due to severe debt.
} 
extremely important financial tool of women religious, one that was strategically deployed in order to maintain the material survival of religious houses. As Caroline Bowden has stated, since English convents often "competed for space with local foundations and were forbidden to solicit alms locally...they were dependent on networks of contacts operating both in expatriate circles and across the channel in England." ${ }^{81}$ The main source of income for convents was derived from the dowries (also known as portions) of recruits and donations from patrons..$^{82}$ Dowry prices could vary considerably over time and between orders, but generally ranged from 300 to 500 pounds. ${ }^{83}$ Rising marriage dowry prices also made convents an attractive alternative for elite families. ${ }^{84}$ English spiritual dowry prices were significantly lower than their continental counterparts, thus making them more appealing to English women. ${ }^{85}$ Some convents also took in lodgers for extra income, but this posed its own challenges given the constraints of enclosure ${ }^{86}$ Further, donations from benefactors occurred as a result of the patronage networks and prestigious reputations that convents established and maintained largely through letter writing.

Who were these women who left their homeland to make the long and expensive journey to the European continent? Claire Walker has estimated that 92 percent of

\footnotetext{
${ }^{81}$ Bowden, "Community Space and Cultural Transmission," 367.

${ }^{82}$ Bowden, "Patronage and Practice," 487.

${ }^{83}$ Walker, Gender and Politics in Early Modern Europe, 32. Bowden has placed the estimate between $£ 200$ and $£ 400$, “General Introduction,” xxiii. In Brussels, for example, dowries ranged from 400 florians to 10,000 florians, Lux-Sterritt, English Benedictine Nuns in Exile in the Seventeenth Century, 69.

${ }^{84}$ Walker, Gender and Politics in Early Modern Europe, 31; for one example of the continental situation see Evengelisti, Nuns: A History of Convent Life 1450-1700, 20.

${ }^{85}$ Lux-Sterritt, English Benedictine Nuns in Exile in the Seventeenth Century, 68-69

${ }^{86}$ Bowden, "General Introduction," xxiii-xxiv.
} 
English women religious came from elite socio-economic backgrounds. ${ }^{87}$ Despite making up the majority of recusant Catholics in England, lower-class families ultimately lacked the financial resources and connections to send their daughters to English convents in exile. ${ }^{88}$ This socio-economic makeup was similar among women religious in continental convents. Silvia Evengelisti has shown that in Milan, three-quarters of women religious came from aristocratic families. ${ }^{89}$ If we think back to English convents as a symbol of a 'living church' preserving Catholicism, then the fact that they drew their members from the highest ranks of English society helps us understand their patrons motivations for funding them. In exchange for financial support, nuns provided lay Catholics (including their family members) with spiritual labour. ${ }^{90}$ This was both a way for English women religious to respond to the needs of recusant Catholics while also serving as an effective tool to ensure their own economic survival. ${ }^{91}$ As we will see, letters allowed this type of spiritual exchange to occur. Further, because they rarely recruited local women, "the English convents in exile became mirrors of recusant circles" that preserved strong ties between the continent and England. ${ }^{92}$ Their cloistered status also meant that women religious relied on external agents to collect money or conduct financial business for

\footnotetext{
${ }^{87}$ Walker, Gender and Politics in Early Modern Europe, 29; Bowden, "General Introduction," $\mathrm{xv}$.

${ }^{88}$ Walker, Gender and Politics in Early Modern Europe, 29.

${ }^{89}$ Evengelisti, Nuns: A History of Convent Life 1450-1700, 5.

${ }^{90}$ For more on this spiritual economy, see Claire Walker, "Combining Martha and Mary," 397418.

${ }^{91}$ Evengelisti, Nuns: A History of Convent Life 1450-1700, 58.

${ }^{92}$ Lux-Sterritt, English Benedictine Nuns in Exile in the Seventeenth Century, 49. Upon their foundation on the continent, English houses had to agree to only take English women. However, this appears to have been more an ideal than reality, as convent records indicate they also recruited some Irish, Scottish, Welsh and French women - see chart in Walker, Gender and Politics in Early Modern Europe, 39.
} 
them. ${ }^{93}$ The dependence on international rather than local contacts made letter writing a crucial medium for woman religious, without which their economic networks could not have been maintained.

The question of choice, or forced entrance, is often raised when discussing the experience of women religious in convents. Although the Council of Trent decreed that "no one shall...compel a woman to enter a Monastery; or prevent her, if she desires to enter," continental religious houses struggled with forced vocations. ${ }^{94}$ Jutta Sperling has shown that in Italian convents, monasticism rates among women from elite backgrounds peaked in the sixteenth and early seventeenth centuries. ${ }^{95}$ Sperling has argued that these entries were often coerced by family members looking to avoid the expensive and dwindling marriage market. ${ }^{96}$ In her analysis of French convents, Elizabeth Rapley has similarly provided evidence that many women were conditioned to become nuns after being placed in convents as young girls, thereby lacking knowledge or experience of the world outside the convent walls. ${ }^{97}$

\footnotetext{
${ }^{93}$ Walker, Gender and Politics in Early Modern Europe, 80.

${ }^{94}$ James Waterworth, The Canons and Decrees of the Sacred and Ecumenical Council of Trent: Celebrated Under the Sovereign Pontiffs, Paul III., Julius III., and Pius IV (London: Burns and Oates, 1848), 249. For a comprehensive examination of continental houses see Evengelisti, Nuns: A History of Convent Life; Penelope D. Johnson, Equal in Monastic Profession: Religious Women in Medieval France. (Chicago: University of Chicago Press, 1991); Jutta Gisela Sperling, Convents and the Body Politic in Late Renaissance Venice (Chicago: Chicago University Press, 2000).

${ }^{95}$ Sperling, Convents and the Body Politic in Late Renaissance Venice, 18.

${ }^{96}$ Sperling shows that elite families were encouraged to marry within their ranks, however, while elite men could marry non-elite women the same practice was discouraged for elite women and convents became the only "honorable alternative", Convents and the Body Politic in Late Renaissance Venice, 18-21. For more on coerced monasticism see Sperling, 29-36.

${ }^{97}$ Rapley, The Dévotes, 186-188; Bowden, "Missing Members," 57.
} 
By contrast, scholars argue that women who entered English convents in exile mostly did so voluntarily. ${ }^{98}$ English convents, therefore, were an exception. Although determining the extent of personal choice is difficult, it is interesting to note that only an estimated three percent of women who joined English convents in exile ended up leaving. ${ }^{99}$ Caroline Bowden has used this low number of "early leavers" to argue explicitly against the idea of forced professions in English convents. ${ }^{100}$ Moreover, the average age of women entering English convents was between 20 and 22 years, which was much higher than continental convents. ${ }^{101}$ While it is possible that some young women were conditioned by family to become nuns, it appears that entry to English convents in exile was largely a choice based on vocation. This can, perhaps, be attributed to the fact that the primary goal of English convents was survival and the preservation of the Catholic faith. In other words, they were far from being simply an alternative for unmarriageable women. ${ }^{102}$ Because of this, English convents in exile also established a more rigorous process of selection that discouraged those without vocations from making the journey to the continent. ${ }^{103}$

The epistolary activity and socioeconomic backgrounds of women religious leads us to consider the educational backgrounds of English nuns. In England, in the sixteenth and seventeenth century there was no formal schooling for girls, thus if they were to

\footnotetext{
${ }^{98}$ Bowden, "Missing Members," 58-65; Lux-Sterritt, English Benedictine Nuns in Exile in the Seventeenth Century, 66-68; Walker, Gender and Politics in Early Modern Europe, 30-38.

${ }^{99}$ Lux-Sterritt, English Benedictine Nuns in Exile in the Seventeenth Century, 67.

${ }^{100}$ Bowden, "Missing Members," 54.

${ }^{101}$ Bowden, "Missing Members," 58.

102 Bowden, "Missing Members," 57-58; Walker, Gender and Politics in Early Modern Europe, $36-37$.

${ }^{103}$ Bowden, "Missing Members," 58-60.
} 
receive an education it occurred within the household. ${ }^{104}$ As Caroline Bowden has stated, the education of girls was more likely to occur within elite families, who also had greater access to books. ${ }^{105}$ In the convent context, English choir nuns were expected to be literate, having the ability to both read and write, as well as a basic knowledge of Latin. ${ }^{106}$ Convents were known to have libraries with spiritual advice and devotional books, lives of saints and martyrs, convent histories and practical manuals. ${ }^{107}$ Although we cannot say for certain, some of these practical manuals may have included letter writing guides. In fact, letter writing guides became increasingly common in the sixteenth and seventeenth centuries, and some were specifically aimed toward women. ${ }^{108}$ As James Daybell has stated, these manuals helped spread vernacular English as well as formalize and standardize letter writing conventions, such as the use of opening and closing addresses, spacing, and dating practices. ${ }^{109}$ Because of the popularity of these manuals, it is possible that English women religious would have read and learned epistolary techniques that than influenced their subsequent letter writing activity.

A convent's reputation played an important role in determining its success and longevity. Convents had to build, and then protect, positive reputations in order to attract recruits with "substantial dowries and patronage from influential and wealthy patrons." Disputes and harmful rumours were to be avoided at all costs. Because of the porous

\footnotetext{
${ }^{104}$ Bowden, "Building Libraries in Exile," 359.

${ }^{105}$ Bowden, "Building Libraries in Exile," 358.

${ }^{106}$ Bowden, "Building Libraries in Exile," 359.

${ }^{107}$ Bowden, "'For the Glory of God'," 88.

${ }^{108}$ Daybell, The Material Letter in Early Modern England: Manuscript Letters and the Culture and Practices of Letter-Writing, 1512-1635 (New York: Palgrave Macmillan, 2012), 20.

${ }^{109}$ Daybell, The Material Letter in Early Modern England, 20.

${ }^{110}$ Bowden, "Collecting the Lives of Early Modern Women Religious," 8.
} 
boundaries of enclosure, scandal seeped quickly into the outside world. ${ }^{111}$ During the Brussels Benedictine dispute (discussed in Chapter Two), the Abbess Mary Percy was concerned that "news of their conflicts would spread beyond the walls of the cloister."112 This fear was confirmed when the convent received a letter from England comparing them to the ruins of Troy. In other words, letters were vital tools for maintaining connections between convents and their patronage networks. But this same contact could also be a disadvantage in times of conflict.

\section{Postal Service \& Letter Delivery}

Letters bridged the gap generated by the geographic distance and physical isolation of English convents, and they were conditioned by the shape of early modern postal services. The post developed quickly between the fifteenth and sixteenth century in the Holy Roman Empire, largely due to the communication needs of the Habsburg dynasty. ${ }^{113}$ The European postal system, whose main route ran from Brussels through the Alps to Italy, relied on "a sequence of horses ridden by a single rider across a series of organised stages." 114 In France, a system of postal couriers were developed as a royal service in $1464 .{ }^{115}$ Although it was heavily policed, and not open to the public, the royal mail system laid the ground work for the French public post established in the seventeenth century. ${ }^{116}$ Given its distance from the continent, England existed "at the

\footnotetext{
${ }^{111}$ Walker, Gender and Politics in Early Modern Europe, 27, 73.

${ }^{112}$ Emilie K. Murphy, "Language and Power in an English Convent in Exile, c.1621-c.1631," Historical Journal 62, no. 1 (2019): 17.

${ }^{113}$ Nikolaus Schobesberger, Paul Arblaster, Mario Infelise, André Belo, Noah Moxham, Carmen Espejo, and Joad Raymond, "European Postal Networks," in News Networks in Early Modern Europe, ed. by N. Moxham and J. Raymond (Leiden: Brill, 2016), 19-20.

${ }^{114}$ Schobesberger, et al., "European Postal Networks," 19-20.

${ }^{115}$ Schobesberger, et al., "European Postal Networks," 33.

${ }^{116}$ Schobesberger, et al., "European Postal Networks," 33.
} 
margins or periphery of the wider European networks." 117 However, some form of a postal service had been present in England since the Roman period. ${ }^{118}$

When it came to postal delivery, senders in both England and on the continent utilized a variety of methods, including packhorses, private carriers, and the post office, "depending on timing, circumstance and urgency." 119 For example, in England, it was relatively inexpensive to hire carriers, but "affordability... was at the expense of speed." ${ }^{120}$ Until the sixteenth century, the Royal Post in England was largely restricted to official government correspondence and not accessible by the rest of the population. ${ }^{121}$ During the reigns of Elizabeth I and James I, however, it "was tacitly opened to private customers," shifting the post from having a solely royal function to becoming one of public use. ${ }^{122}$ In major merchant cities, there was a well-established international merchant post, with couriers conveying letters within the continent, as well as to and from England. ${ }^{123}$ When examining the development of postal networks it is evident that "although locally variable in their administration and in the speed with which they were established, they were fundamentally transnational in their conception."124 These networks allowed women religious the ability to maintain transnational links through their letters.

\footnotetext{
${ }^{117}$ Schobesberger, et al., "European Postal Networks," 46.

${ }^{118}$ Lindsay O'Neill, The Opened Letter: Networking in the Early Modern British World (Philadelphia: University of Pennsylvania Press, 2014), 21.

${ }_{119}$ Daybell, The Material Letter in Early Modern England, 109; Schobesberger, et al., "European Postal Networks," 48-50.

${ }^{120}$ Daybell, The Material Letter in Early Modern England, 134.

${ }^{121}$ Daybell, The Material Letter in Early Modern England, 109.

${ }^{122}$ Schobesberger, et al., "European Postal Networks," 53-54

${ }^{123}$ Daybell, The Material Letter in Early Modern England, 137; Schobesberger, et al., "European Postal Networks,", 21, 58.

${ }^{124}$ Schobesberger, et al., "European Postal Networks," 62.
} 
Even with the development of the post office, some continental monasteries continued to send letters by "private couriers, by ships' captains, or through trade connections that were not strictly postal." 125 In her letters, Abbess Mary Knatchbull mentioned multiple times waiting for the post to arrive. At one point, she urged her correspondent "send $\mathrm{yo}^{\mathrm{r}}$ servant every night to the post house...for the posts are very negligent in their duty." ${ }^{126}$ Her repeated references to the post service in her letters indicate that she was utilizing a fairly regular, if slow or careless, postal service.

One of the biggest issues that women religious faced in regard to letter writing was failure or interception of the post. In fact, as James Daybell has shown, in England, "from the Elizabethan period onwards, there was a concerted effort to control official post delivered overseas." 127 This effort seems to have been successful, as evidenced by a large collection of nuns' letters intercepted in the 1650's by John Thurloe, England's Secretary of State and head of intelligence services. ${ }^{128}$ One contemporary estimate stated that the post failed to deliver three out of every four letters, thanks in part to Thurloe's intelligence operations. ${ }^{129}$ Whether it was through the post office or private carriers, early modern letter writers came to expect that their correspondence would be intercepted. ${ }^{130}$

\footnotetext{
${ }^{125}$ Schobesberger, et al., "European Postal Networks," 25. It is difficult to determine exactly which method of postal transmission English convents utilized during this period. However, postal markings or stamps, if present on letters, can give us an indication of whether the official post service was used, and when the letter entered its care.

${ }^{126}$ Bodleian Library, Oxford, Clarendon State Papers, Sept 1659, MS. Clarendon 64, fol. 258. Mary Knatchbull and her network will be discussed in Chapter 3.

${ }^{127}$ Daybell, The Material Letter in Early Modern England, 119.

${ }^{128}$ These letters written in March 1655 by women religious at Cambrai are now preserved in the Bodlelian Library, Oxford, as Thurloe's Papers Vol. XXXVI, March 1656, Rawlinson MS A.36 and will be discussed in Chapter 2. The underlying rhetoric of surveillance and interception in English postal service is evidenced by the "Act for the Setling of the Postage of England, Scotland and Ireland' from 1657, Schobesberger, et al., "European Postal Networks," 54-55. ${ }^{129}$ Walker, "Prayer, Patronage, and Political Conspiracy," 9.

${ }^{130}$ How, Epistolary Spaces, 5.
} 
For example, Winefrid Thimelby, a nun who will be discussed in detail in Chapter One, explicitly mentioned the possibility of her letters being intercepted. Regarding a missing letter to her sister, she wrote that it would not be "the first of mine, $\mathrm{w}^{\mathrm{ch}}$ hath miscared."131 Because letter writing was a "reciprocal activity," intercepted letters or prolonged silences created anxiety among correspondents. ${ }^{132}$ In another of Winefrid's letters, this time to her brother-in-law, her unease and frustration is evident when she writes, "I suspect mischariage $[o f]$ letters has rob'd me of many a good bitt" of news. ${ }^{133}$ Other women religious echoed these frustrations.

It is interesting to consider how this anxiety affected letter writing practices. Put simply, the threat of interception, "heightened the degree of epistolary insecurity... which affected the very nature of correspondence, causing writers to self-censor," or even resort to coded messages. ${ }^{134}$ One example of this anxiety can be seen in a letter of Clare Conyers to her cousin Isaac Young in $1791 .{ }^{135}$ Writing as an eyewitness to a period of heightened religious tension in France, Clare Conyers writes, "I did intend to give you an account...but dare not as my Letter is to goe by the post for fear of its being opend."136 Other women religious, such as Mary Knatchbull, used code names in order to avoid

\footnotetext{
${ }^{131}$ BL Add. MS 36 452, fol. 63. These letters can be found at the British Library, Aston Papers Vol. IX, Additional MS 36 452. Edited transcriptions of five letters can also be found in English Convents in Exile, 1600-1800: Volume 3, 263-272.

${ }^{132}$ Daybell, The Material Letter in Early Modern England, 143.

${ }^{133}$ BL Add. MS 36 452, fol. 90.

${ }^{134}$ Daybell, The Material Letter in Early Modern England, 147.

${ }^{135}$ Clare Conyers (AP031) in WWTN < https://wwtn.history.qmul.ac.uk> [accessed Nov 23 2019]. Edited transcriptions of four letters can be found in "Poor Clares of Aire: Correspondence of the Conyers Family," in English Convents in Exile, 1600-1800: Volume 6: The Convents and the Outside World, ed. by Carmen M. Mangion, Michael Questier, Emma Major and Caroline Bowden (London: Pickering \& Chatto, 2012), 383-389.

${ }^{136}$ Clare Conyers to Isaac Young, January 3, 1791 in English Convents in Exile, 6: 385.
} 
detection of her royalist postal network. ${ }^{137}$ Overall, we can see that the nature of the postal service and the development of letter writing practices were unmistakably interconnected.

\section{Thesis Structure}

The majority of letters examined in this thesis come from the seventeenth and eighteenth centuries, coinciding with the establishment of the first English convent on the continent until their dissolution or return to England. Chapter One will examine letter writing in a convent context, including the importance of the Council of Trent mandate on enclosure and restrictions placed on letters and outside communication. More significantly, it will analyze the familial letters of women religious, particularly Winefrid Thimelby, Mary Caryll, Arabella Benedicta Caryll and the Hagan Sisters, to explore how family connections were maintained and exploited through epistolary exchange. Chapter Two will examine correspondence in the context of convent disputes, with particular reference to two incidents, the Cambrai book dispute and the Brussels Benedictine controversies. These disputes reveal that while letters gave nuns a voice in times of conflict, and recourse to exert control over their circumstances, open channels of communication were not without their drawbacks. Finally, Chapter Three will explore the correspondence of Mary Knatchbull, who not only wrote letters, but served as an intermediary and confidant, passing news and intelligence through her convent. Her letters are markedly political and diplomatic in content and purpose, illustrating how letters are what allowed women religious to be actively involved in the public sphere outside their convent walls.

\footnotetext{
${ }^{137}$ Bowden, "The Abbess and Mrs. Brown," 288-208; Walker, "Loyal and Dutiful Subjects," 228-242; "Crumbs of News," 635-655.
} 


\section{Chapter 1: Letters to Family \& Friends From Exile}

\section{English Convents on the Continent}

The seventeenth and eighteenth centuries saw a boom in English convent formation on the European continent. Between 1600 and 1800, 23 English convents were established and an estimated 3,271 women became nuns. ${ }^{138}$ This chapter explores letters written by women religious in exile to family members and friends in England and abroad. The letters of Winefrid Thimelby, who wrote dozens of letters to her family back in England during her time in exile, provide an opportunity to illustrate how family bonds maintained a significant presence in women religious' lives. The correspondence of Mary Caryll, Abbess of the Dunkirk Benedictines, to her brother John Caryll, differs significantly in tone and content from Winefrid Thimelby's, but it exemplifies how letters to family had strategic and economic objectives. The letters of the four Hagan sisters, in France, to Father Bolton in Maryland, allow insight into inter-convent communication and demonstrate the power of letters to maintain global connections. Finally, the letters of Arabella Benedicta Caryll provide a glimpse into how relationships could break down as generational ties became further removed. By comparing these individual experiences and uses of epistolary space, we gain a greater understanding of the multifaceted ways women religious in exile utilized familial letters.

\footnotetext{
${ }^{138}$ See chart in Caroline Bowden, James E. Kelly, and Michael C. Questier, "Introduction," in The English Convents in Exile, 1600-1800, ed. by C. Bowden and J. E. Kelly (Burlington, VT: Ashgate, 2013), 16; Claire Walker, Gender and Politics in Early Modern Europe: English Convents in France and the Low Countries (New York: Palgrave Macmillan, 2003), 2.
} 


\section{Council of Trent \& Enclosure}

As the letters that will be examined throughout this thesis will show, a convent's survival required careful negotiation of, and direct contact with, the outside world. This was easier said than done, however. In 1545, Pope Paul III convened the Council of Trent as part of the Catholic Church's response to the Protestant Reformation, and for over almost twenty years it issued key declarations on church doctrine. ${ }^{139}$ The aim of the Council was to "regulate religious institutions by returning them to what the Church defined as traditional monastic discipline." ${ }^{140}$ Implementing clausura, or strict enclosure, quickly became essential to achieving Tridentine reform. On December $3^{\text {rd }}, 1563$, at the twenty-fifth session of the Council, the decree on enclosure was confirmed. It commanded that:

"All monasteries...make it their especial care that the enclosure of nuns be carefully restored wheresoever it has been violated; and that it be preserved wheresoever it has not been violated... for no nun, after her profession, shall it be lawful to go out of her convent, even for a brief period, under any pretext whatever, except for some lawful cause, which is to be approved of by the bishop... and it shall not be lawful for anyone...to enter within the enclosure of a nunnery, without the permission of the bishop." 141

The Council of Trent decree explicitly drew upon medieval efforts to enforce strict enclosure on nuns. This included, most notably, Pope Boniface VIII's Bull Periculoso

\footnotetext{
${ }^{139}$ For a selection of sources on the Council of Trent see James Waterworth, The Canons and Decrees of the Sacred and Ecumenical Council of Trent: Celebrated Under the Sovereign Pontiffs, Paul III, Julius III, and Pius IV (London: Burns and Oates, 1848); John W. O'Malley, Trent: What Happened at the Council (Harvard University Press, 2013). For the Council's impact on monastic communities see Craig Harline, "Actives and Contemplatives: The Female Religious of the Low Countries Before and After Trent," Catholic Historical Review 81, no. 4 (1995): 54167; Alexandra Walsham, "Translating Trent? English Catholicism and the Counter Reformation," Historical Research 78, no. 201 (2005): 288-310.

${ }^{140}$ Walker, Gender and Politics in Early Modern Europe, 46.

${ }^{141}$ Waterworth, The Canons and Decrees of the Sacred and Ecumenical Council of Trent, 240.
} 
from 1299, which became the "first general regulation on the subject...[and] binding as...law upon the whole church." ${ }^{142}$ The objective of Periculoso was clear:

"To provide for the perilous and detestable state of certain nuns, who, having slackened the reins of decency and having shamelessly cast aside the modesty of their order and of their sex...we by the present constitution...decree with healthful intent that all and sundry nuns, present and future, to whatever order they belong, and in whatever part of the world, shall henceforth remain perpetually enclosed within their monasteries." 143

However, the ideology behind enclosure had its roots long before the thirteenth century, and can be traced back to "the monastic ideal of 'fuga mundi', the flight from the world" originating with desert hermits. ${ }^{144}$ And yet, as Eileen Power remarked, "for the next three centuries Councils and Bishops struggled...to put into force the Bull Periculoso, but without success; the constant repetition of the order...is the measure of its failure."145 Ultimately, the Council of Trent's decree was a sixteenth century reiteration of what had been attempted in the thirteenth century.

Letters challenged enclosure by their very existence. As Claire Walker has argued, "letters not only brought news of worldly affairs into the cloister, they discouraged nuns from breaking emotional ties with their kin." ${ }^{146}$ For women religious, being removed from the world physically was not enough, connections with the outside world had to be

\footnotetext{
${ }^{142}$ Eileen Power, Medieval English Nunneries, c. 1275 to 1535 (New York: Biblo and Tannen, 1964), 344.

${ }^{143}$ Power, Medieval English Nunneries, 344.

${ }^{144}$ Francesca Medioli, “An Unequal Law: The Enforcement of Clausura Before and After the Council of Trent," in Women in Renaissance and Early Modern Europe, ed. by Christine E. Meek (Dublin: Four Courts Press, 2000), 139.

${ }^{145}$ Power, Medieval English Nunneries, 345.

${ }^{146}$ Claire Walker, "'Doe not supose me a well mortifyed Nun dead to the world': Letter-writing in Early Modern English Convents," in Early Modern Women's Letter-Writing, 1450-1700, ed. by J. Daybell (Basingstoke: Palgrave, 2001), 161.
} 
broken "psychologically as well as spatially." 147 The objective of a contemplative nun "was to be dead to the world, to others, and to oneself, to embrace life in the spiritual pursuit of God only." 148 In fact, the statute of the Brussels Benedictine convent, created in 1612, emphasized the need to limit outside contact when it stated, "a Religious person ought to bee very sparing in that kinde, as benig [sic] one deade to the world, and that desyreth onely to live to Christ alone." 149 Yet, as the content of nuns' letters indicate, many women religious struggled to achieve complete separation. Letters therefore allow us to think about breaches of enclosure in a different way. Rather than physically breaking enclosure, letters allowed for psychological breaches that actively preserved emotional and strategic connections to the outside world.

It is important to recognize that the rhetoric around enclosure was extremely gendered. As Eileen Power has pointed out, "the history of the enclosure movement is in effect the history of an effort to add a fourth vow of claustration to the three cardinal vows of the nun." 150 This effort was driven by the rhetoric of protecting female chastity and honour. ${ }^{151}$ In her book on Neapolitan convents, Helen Hills has equated enclosure with incarceration and policing, a force of female control dictated by men. ${ }^{152}$ Perhaps one of the reasons that women religious incited more anxiety than their male counterparts can attributed to their class backgrounds. Most choir nuns, English and continental, came

\footnotetext{
${ }^{147}$ Laurence Lux-Sterritt, English Benedictine Nuns in Exile in the Seventeenth Century: Living Spirituality. (Manchester: Manchester University Press), 30.

${ }^{148}$ Lux-Sterritt, English Benedictine Nuns in Exile in the Seventeenth Century, 23.

${ }^{149}$ Statutes Compyled for the Better Observation of the Holy Rule of the Most Glorious Father and Patriarch S. Benedict (Ghent, 1632), 38. Hereafter Brussels Benedictine Statutes. I am grateful to Jaime Goodrich for sharing a copy of the statutes with me.

${ }^{150}$ Power, Medieval English Nunneries, 342.

${ }^{151}$ Walker, Gender and Politics in Early Modern Europe, 46-47.

${ }^{152}$ Helen Hills, Invisible City: The Architecture of Devotion in Seventeenth Century Neapolitan Convents (New York: Oxford University Press, 2004), 63.
} 
from elite or "the highest gentry" families, which made controlling their purity even more important. ${ }^{153}$ Nevertheless, Doris Gottemoeller has argued that the fact that nuns were singled out over their male counterparts suggests that, "the preference for enclosure for women was fed in part by a patronizing attitude toward women, the belief that they were the weaker sex, more liable...to be harmed by contact with the world." ${ }^{154}$ This attitude can even be traced back to Pope Boniface VIII's Bull Periculoso in which, as Jo Ann McNamara states, he "stressed the peril of men's inability to resist raping women and women's natural inability to refrain from tempting men." ${ }^{155}$ The important point here is that enclosure was rhetorically held up as an extremely significant requirement of nuns and only nuns.

After the Council of Trent, "seventeenth century...nuns observed separation from the world in a much more rigorous manner than their medieval forebears had done," at least in theory. ${ }^{156}$ The constitutions and rules of various orders placed a great deal of importance on maintaining enclosure. As Helen Hills has argued regarding Italian convents, "the respectability and prestige of convents were measured...by the effectiveness of their enclosure, the symbol of their separation from the world, and the

\footnotetext{
${ }^{153}$ Liesbeth Corens, "Catholic Nuns and English Identities. English Protestant Travellers on the English Convents in the Low Countries, 1660-1730," Recusant History 30, no. 3 (2011): 442; Walker, Gender and Politics in Early Modern Europe, 29-31; Ulrike Strasser, State of Virginity: Gender, Religion, and Politics in an Early Modern Catholic State (Ann Arbor: University of Michigan Press, 2004), 120.

${ }^{154}$ Doris Gottemoeller, "Religious Life for Women: From Enclosure to Immersion," in From Trent to Vatican II: Historical and Theological Investigations, ed. by Raymond Bulman and Frederick Parella (New York: Oxford University Press, 2006), 231. Ulrike Strasser also discusses the gendered nature of reform in her book State of Virginity, particularly pp. 71-77.

${ }^{155}$ Jo Ann McNamara, Sisters in Arms: Catholic Nuns through Two Millennia (Cambridge, MA: Harvard University Press, 1996), 317.

${ }^{156}$ Lux-Sterritt, English Benedictine Nuns in Exile in the Seventeenth Century, 28.
} 
guarantee of the virginity of the disciplined bodies inside." ${ }^{157}$ The same rhetoric can be found in English convents. For example, the Carmelite order followed the Rule of St Albert, first developed in 1209 but modified by Teresa de Jesus in 1562, which emphasized strict enclosure and outlined punishments, such as imprisonment inside the convent, for those who broke the rule. ${ }^{158}$ The Brussels Benedictine statute, which was also used at Dunkirk, Ghent, Pontoise (Boulogne), and Ypres, included guidelines for how enclosure should be enforced. Chapter five of the statute indicated that women religious "must have a speciall care of keeping their Inclosure...commaunded by the sacred Counsell of Trent" and stipulated that "noe professed Religious may goe out of this Inclosure, but uppon constraynte of fyre, extreme famyne, war...or other cases approved uppon urgent necessitie." ${ }^{159}$ In other words, breaches of enclosure were permissible, but only in extreme circumstances. In fact, the letters of women religious provide us with examples of the permeability of enclosure. A letter from Frances Huddleston, written to her nephew Ferdinand in 1756, explains how the nuns were forced to break enclosure after an earthquake and fire the previous year destroyed their convent. ${ }^{160}$ Women religious were also advised to keep track of anyone who entered the convent, such as workers, and accompany them at all times. ${ }^{161}$ At the Augustinian

\footnotetext{
${ }^{157}$ Helen Hills, Invisible City, 124.

${ }^{158}$ Nicky Hallett, Lives of Spirit: English Carmelite Self-Writing of the Early Modern Period (Aldershot: Ashgate, 2007), 241-242.

${ }^{159}$ Brussels Benedictine Statutes, The First Parte, 18-19.

160 "Letters to and From Bruges, Lisbon and Paris: Correspondence of the Huddleston Family," in English Convents in Exile, 1600-1800: Volume 3. Life Writing I, ed. by Nicky Hallett, Elizabeth Perry and Victoria Van Hyning (London: Pickering \& Chatto, 2012), 295, 300-301. See entry for Frances Huddlestone (LB093) in WWTN $<$ https://wwtn.history.qmul.ac.uk> [accessed Jan 23 2020].

${ }^{161}$ Brussels Benedictine Statutes, The First Parte, 21.
} 
convent in Paris, the constitution set out regulations for interactions between outsiders and women religious. It stipulated that the visitor - or caller - must first:

"present themselves to the Porteress (an office held by a senior nun) at her lodge near the gate...If the caller wished to speak to a particular nun, the Porteress informed the Superior...If the Superior gave her consent, the caller was...directed to one of the parlours where he or she could communicate with the nun through a grille. She was always accompanied by another nun designated by the Superior... [and] no visit was to last longer than an hour." 162

As this example shows, contact with the outside world was possible, and even at times allowed, but nevertheless required constant scrutiny and regulation.

With rules on enclosure in mind, it is important to note that English women religious did not overtly reject or revolt against enclosure. ${ }^{163}$ Some women religious found the implementation of enclosure to be "something which liberated them from restrictions imposed by the outside world." 164 And yet, accepting enclosure did not mean that women religious were therefore the "victims of unremitting patriarchal control."165 To consider Tridentine reforms, and the history of the Catholic church more generally, as simply a top down attempt by men to control women, effectively negates the agency that nuns had in navigating the boundaries of monastic life. ${ }^{166}$ While the effects of the Council of Trent should not be dismissed, the broader point is that the history of women

\footnotetext{
${ }^{162}$ Antony F. Allison, "The English Augustinian Convent of our Lady of Syon at Paris: Its Foundation and Struggle for Survival during the First Eighty Years, 1634-1713," Recusant History 21, no. 4 (1993): 462.

${ }^{163}$ For some examples of resistance in continental convents see Strasser, State of Virginity, 119148.

${ }^{164}$ Silvia Evengelisti, Nuns: A History of Convent Life 1450-1700 (Oxford: Oxford University Press, 2007), 7.

${ }^{165}$ Walker, Gender and Politics in Early Modern Europe, 44.

${ }^{166}$ Ulrike Strasser, "Clara Hortulana of Embach or How to Suffer Martyrdom in the Cloister," in Female Monasticism in Early Modern Europe, ed. by Cordula van Wyhe (Burlington VT: Ashgate, 2008), 40; Elizabeth A. Lehfeldt, "The Permeable Cloister," in The Ashgate Companion to Women and Gender in Early Modern Europe, ed. by Jane Couchman, Allyson M. Poska, and Katherine A. McIver (Abingdon: Routledge, 2013), 22.
} 
religious was not purely defined by tension between enclosure "and a more open model of religious life." ${ }^{167}$ Instead, some women religious willingly embraced enclosure, while others rebelled against it.

English convents in particular, Caroline Bowden argues, "were aware of the importance of following the rule and constitutions closely in order to establish a reputation," which was key to attracting the recruits and patronage necessary for survival. ${ }^{168}$ In fact, the Council of Trent's insistence on strict enclosure could be utilized to a nun's benefit. By being confined to a contemplative rather than a missionary life, women religious gained "the monopoly on prayer," which they were able to manipulate to their own financial benefit. ${ }^{169}$ In some instances, enclosure could be negotiated outright. Women religious, for example, could petition the bishop for permission to leave the convent in order to collect money owed to them or conduct other financial business. ${ }^{170}$ Even the physical architecture of convents could undermine the ideal of enclosure. ${ }^{171}$ The Benedictine Rule theoretically guaranteed enclosure when it indicated that: "their inclosure must bee envyroned with high Walls...soe that none from abroade may enter into this Inclosure, by any Stayres, or Gates, but onely by one dore or Gate."172 However, there were small openings known as "turns" which "permitted the passing of

\footnotetext{
${ }^{167}$ Evengelisti, Nuns: A History of Convent Life 1450-1700, 6.

${ }^{168}$ Caroline Bowden, "Missing Members: Selection and Governance in the English Convents in Exile," in The English Convents in Exile, 1600-1800, ed. by Caroline Bowden and James E. Kelly (Burlington, VT: Ashgate, 2013), 56.

${ }^{169}$ Walker, Gender and Politics in Early Modern Europe, 91.

${ }^{170}$ Walker, Gender and Politics in Early Modern Europe, 122.

${ }^{171}$ On convent architecture see, Helen Hills, Invisible City; Roberta Gilchrist, Gender and Material Culture: The Archeology of Religious Women (New York: Routledge, 1994).

${ }^{172}$ Brussels Benedictine Statutes, The First Parte, 19.
} 
food, documents or other objects into the convent." 173 Although these were monitored closely, regular contact did occur. And therein lies the contradiction at the heart of enclosure. The reality of convent life inevitably required contact with the outside world.

\section{Letter-Writing in a Convent Context}

When it comes to interpreting the rules of monastic life or enforcing the reforms of the Council of Trent, each order was unique. There were two types of documents that nuns based their lives on; "first, the rule derived from the order (for example Benedictine or Augustinian), and second each convent's unique constitutions or statutes."174 Letter writing did not escape the attention of these rules. In fact, the Brussels Benedictine statute dedicated an entire chapter to letter writing. In terms of letter content, the Brussels Benedictine statute placed an emphasis on writing letters solely so that "frends may receave Edification, and spirituall proffitt from them." ${ }^{175}$ The Brussels statute is just one example of the desire to regulate letter writing in female monastic orders.

The Augustinians had similar regulations around letter writing for women religious. As we will see, the Augustinian confessor at St. Monica's, Richard White, was deeply concerned with reforming nuns' epistolary activity. Although not mentioning letters explicitly, the Carmelite constitution stipulated that women religious "wth draw as much as conueniently they can dealing wth their parents, because besides ye affection to their affaires, it would be difficult not to inter medle wth wordly things." 176 Moreover, a

\footnotetext{
${ }^{173}$ Caroline Bowden, "Patronage and Practice: Assessing the Significance of the English Convents as Cultural Centres in Flanders in the Seventeenth Century," English Studies 92, no. 5 (2011): 489.

${ }^{174}$ Caroline Bowden, "Community Space and Cultural Transmission,": Formation and Schooling in English Enclosed Convents in the Seventeenth Century," History of Education 34, no. 4 (2005): 368.

${ }^{175}$ Brussels Benedictine Statutes, The First Parte, 38.

176 "The Constitutions and Rule of St Albert" quoted in Hallett, Lives of Spirit, 246.
} 
seventeenth century manuscript from the Lierre Carmels reveals that one way of testing the obedience of nuns was to "shew them [a] letter receaued \& not giue them; \& sometime giue them \& forbed them to read them."177 The fact that letters were used to test a nun's obedience is further evidence that they were seen as a threat that needed to be mitigated. From this, we can see that a strong emphasis was placed on keeping women religious removed from the world, both physically and in their communication. And yet for religious women enclosed in convents, "letter-writing and letter-exchange were important mechanisms by which women could continue to participate in the interests and concerns of their natal family." ${ }^{178}$ As the letters that will be examined in this chapter demonstrate, concern for, and updates on, their family's well-being was one of the most prominent themes of nuns writing.

Beyond what convent rules stipulated, one also has to consider the role that the Abbess, or other most senior office holder in the convent, played in shaping letter writing regulations. ${ }^{179}$ The Council of Trent, stipulated that, in order to be elected to as Abbess, a nun had to be at least 40 years of age and have spent "eight...years in a praiseworthy manner, after having made her profession." ${ }^{180}$ Election often lasted for life. ${ }^{181}$ When it came to monitoring communication, "abbesses were required to censor all mail leaving

\footnotetext{
${ }^{177}$ Nicky Hallett, Lives of Spirit, 261-262.

${ }^{178}$ Susan Broomhall, "Letters Make the Family: Nassau Family Correspondence at the Turn of the Seventeenth Century," in Early Modern Women and Transnational Communities of Letters, ed. by Julie D. Campbell and Anne R. Larson (Burlington, VT: Ashgate, 2009), 28.

${ }^{179}$ In some houses, such as the Augustinians in Louvain and Bruges, the most senior office holder was called the Prioress and "was elected by the community and served for life or as long as her health allowed," Victoria Van Hyning, Convent Autobiography: Early Modern English Nuns in Exile (Oxford: Oxford University Press, 2019), xxvii.

${ }^{180}$ Waterworth, The Canons and Decrees of the Sacred and Ecumenical Council of Trent, 242

${ }^{181}$ Lux-Sterritt, English Benedictine Nuns in Exile in the Seventeenth Century, 65.
} 
and entering their house." 182 This is consistent with the Brussels Benedictine Statute, which explicitly stated that all letters or other types of mail, such as tokens, must go through the Prioress or the Abbess, who delivered them as they saw fit. ${ }^{183}$ The Benedictine Statute also indicated that no letters to friends or family could be sent "without the knowledge of the Abbesse, and without her consent...[the Religious must] leave it to her judgment, whether shee wll send them or noe." 184 And this was not confined simply to the Benedictine orders. The constitutions of the Carmel order in Lierre required that women religious "giue letters to noe body but ye Pryorese, who shall first redde them," and if one was caught disobeying this rule it was considered a "Grieuous Fault." 185 A letter of Clare Conyers, a Poor Clare at Aires, sheds light on the role of superiors in shaping letter writing. She wrote, "our letters are first taken to a Superior \& read by her before they are given to a Sister, but we are sometimes obliged to change our derections." ${ }^{186}$ Fundamentally, the goal here was that "a nun only writes about matters that will not endanger her soul; that she does not speak ill of her community and...promotes the well-being of the convent." ${ }^{187}$ In other words, the abbess had a great deal of power to control the flow of information entering, and leaving, the convent. As

\footnotetext{
${ }^{182}$ Walker, “'Doe not supose me a well mortifyed Nun dead to the world',"161.

${ }^{183}$ Brussels Benedictine Statutes, The First Parte, 37-38.

${ }^{184}$ Brussels Benedictine Statutes, The First Parte, 38-39.

${ }^{185}$ James E. Kelly, "Jesuit News Networks and Catholic Identity: The Letters of John Thorpe to the English Carmelite Nuns at Lierre, 1769-89," in Jesuit Intellectual and Physical Exchange Between England and Mainland Europe, c.1580-1789, ed. by James E. Kelly and Hannah Thomas (Boston: Brill, 2018), 339.

${ }^{186}$ Clare Conyers to Isaac Young, December 19, 1788, in "Poor Clares of Aire: Correspondence of the Conyers Family," in English Convents in Exile, 1600-1800: Volume 3. Life Writing I, ed. by Nicky Hallett, Elizabeth Perry and Victoria Van Hyning (London: Pickering \& Chatto, 2012), 281.

${ }^{187}$ Victoria Van Hyning, "Poor Clares of Aire: Correspondence of the Conyers Family," in English Convents in Exile, 1600-1800: Volume 3. Life Writing I, ed. by Nicky Hallett, Elizabeth Perry and Victoria Van Hyning (London: Pickering \& Chatto, 2012), 274.
} 
we will see in Chapter Two, this power could be abused, or viewed suspiciously by other nuns.

\section{"As if I had never left": The Letters of Winefrid Thimelby}

Given the physical separation dictated by enclosure, letter writing was the most important tool at a nun's disposal to communicate with the outside world. One nun who utilized this medium was Mary Thimelby, known in religion as Winefrid, who professed with the Augustinians at St Monica's in Louvain, Belgium around 1635 and died there in 1690. ${ }^{188}$ During this period, Thimelby wrote at least thirty four letters to her family in England, specifically to her older sister Katherine, her brother-in-law Herbert Aston, and her various nieces and nephews. ${ }^{189}$ Thimelby's writing is only one part of the larger Aston-Thimelby family, which was defined by "extensive outward connections" and whose correspondence and Catholic faith fostered connections with other recusant families. ${ }^{190}$ Thimelby's letters illustrate that she sought out news of her family and life back in England, while also sharing news of her own convent and activities on the

\footnotetext{
${ }^{188}$ Mary Thimelby (LA261) in WWTN < https://wwtn.history.qmul.ac.uk> [accessed Oct 5 2019]. Thimelby's letters were first edited and published by Arthur Clifford in 1815 as the Tixall Letters; or the Correspondence of The Aston Family and their Friends during the seventeenth century. Since then, Thimelby's letters have received crucial analysis by a handful of scholars, including Claire Walker, “'Doe not supose me a well mortifyed Nun dead to the world,' 168-170; Julie C. Sanders, "Tixall Revisited: The Coterie Writings of the Astons and Thimelbys in Seventeenth-Century Staffordshire," in Women Writing 1550-1750, ed. by J. Wallwork and P. Salzman (Bundoora: La Trobe University, 2001), 47-57; Mareile Pfannebecker, "Love's Interest': Agency and Identity in a Seventeenth-Century Nun's Letters," Literature Compass 3, no. 2 (2006): 149-158; Van Hyning, Convent Autobiography, 37-82.

${ }^{189}$ This figure is based on the number of letters preserved in the British Library, Aston Papers Vol. IX, Additional MS, 36 452. It is unknown how many more letters Thimelby may have written that have not been preserved.

${ }^{190}$ Helen Hackett, "Women and Catholic Manuscript Networks in Seventeenth-Century England: New Research on Constance Aston Fowler's Miscellany of Sacred and Secular Verse," Renaissance Quarterly 65, no. 4 (2012): 1101-1102.
} 
continent. ${ }^{191}$ Unfortunately, the letters from the Thimelby-Aston family to Winefrid have largely been lost, leaving us with only one half of the conversation.

Winefrid Thimelby's letters are unique, as we shall see, for their style and tone, which set them apart from the correspondence of other women religious. Her letters provide insight into family relations during this period, as well as how nuns responded to restrictions placed upon them. In 1668, the confessor at Louvain, Richard White, created his "Instructions for a Religious Superior," which placed significant emphasis on enclosure and letter writing. ${ }^{192}$ In one section, White stated that, "no time is more unprofitably spent, nor no greater occasion of distraction, then in idle correspondence of unnecessary letters." ${ }^{193}$ In practical terms, White's guidelines meant that "the prioress could write to kin once or twice a year, if her family so desired; her nuns were permitted only one such letter." 194 Not only did White see letters as a threat to the continuation of enclosure, but the very fact that this type of instruction was issued demonstrates how important and prevalent letter writing was in English convents.

Thimelby, as the convent's prioress would have been aware of White's instructions and encouraged to follow them strictly. It has been argued that Thimelby largely followed the convent statutes and wrote only once a year to her family. ${ }^{195}$ And yet, it is unclear exactly what Thimelby thought about the rules on letter writing and if she saw her writing

\footnotetext{
${ }^{191}$ Walker, "'Doe not supose me a well mortifyed Nun dead to the world"," 159.

${ }^{192}$ Walker, "'Doe not supose me a well mortifyed Nun dead to the world'," 162.

${ }^{193}$ Priory of Our Lady, St. Monica's MS Qu2 f.3: Richard White. 'Instructions for a Religious Superior', 1668, quoted in Walker, "'Doe not supose me a well mortifyed Nun dead to the world'," 162.

${ }^{194}$ Walker, "“Doe not supose me a well mortifyed Nun dead to the world'," 162.

${ }^{195}$ Victoria Van Hyning, "Thimelby-Aston Literary Exchanges: 'Itt imports not wher but how we live'," in English Convents in Exile, 1600-1800: Volume 3. Life Writing I, ed. by Nicky Hallett, Elizabeth Perry and Victoria Van Hyning (London: Pickering \& Chatto, 2012), 263.
} 
to be in line with religious ideals, or as a breach of enclosure. In her introduction to

Thimelby's letters, Victoria Van Hyning has argued that:

"her reputation within modern scholarship as a nun who breached clausura with her animated correspondence, thus clinging to worldly relationships, should be reconsidered in light of what her letters ultimately achieved: eternal union with friends and family, and the maintenance of their collective faith."196

However, a close reading of Thimelby's letters indicates that she struggled to emotionally navigate her desire to be a 'good' nun with her desire to remain connected to family. In one of her letters, in fact, Thimelby appears conscious of the contradictory nature of her actions. She writes, "really, I wod faine love nothing but God, but all you at Bellamour are notorious theefs... and steal or rather openly rob of that poor interest I should pay only to Heaven." ${ }^{\prime 197}$ Regarding this quote, Mareile Pfannebecker has argued that Thimelby was deeply "aware of...[the] pressure and the regulations it was her responsibility to enforce," while also experiencing "remorse for her indulgence in social contacts." ${ }^{198}$ Using the metaphor of her family as thieves of her love, Thimelby highlights the paradox that surrounded her letter writing experience. Claire Walker has argued that when it comes to the content of Thimelby's correspondence, "passionate discourse was common among her kin, [but] was hardly sentiment or language suitable in a nun."199 Thimelby's letters underscore the limitations of enclosure. While she might not have seen her acts as transgressive, she nevertheless held a deep attachment to the world outside her convent walls that physical separation could not mitigate.

\footnotetext{
${ }^{196}$ Victoria Van Hyning, “Thimelby-Aston Literary Exchanges,” 264.

${ }^{197}$ BL Add. MS 36 452, fol. 100.

${ }^{198}$ Mareile Pfannebecker, “'Love's Interest',"153.

${ }^{199}$ Walker, "'Doe not supose me a well mortifyed Nun dead to the world'," 168.
} 
While only two of Thimelby's letters, written almost a year apart to her sister Katherine, remain, they allow us a glimpse into sibling relations in the early modern world. ${ }^{200}$ Recent examinations have argued that there were four key aspects of early modern sibling bonds, "reciprocity, affection, competition, and alliance building." ${ }^{201}$ The first two are clearly evident in Thimelby's letters. When it comes to reciprocity, one of Thimelby's letters opens with a quip about her sister's insistence on having her portrait painted. She wrote, "were it possible to be angry with you thess lins wod chide $\mathrm{y}^{\mathrm{r}}$ kind folly in desiring my picture...the truth is I can deny you nothing." ${ }^{202}$ Yet Winefrid and Katherine's relationship was not always jovial. In her next letter, Thimelby begins by complaining about her sister's lack of correspondence. She writes, "I may as well complayne sence tis a whole yeare sence I receaved line from you. ${ }^{" 203}$ Thimelby spends the rest of the letter attempting to reassure her sister of her love. She continues, "so carefull selfe love made me to soe my seede in hope to reape the pleasing fruit of youre answers but when they fayled I never did admitt a thought your love did to. Sweet sister doe the same by mee who willingly confesse you goe before me in all except a constant love." ${ }^{204}$ Although separated, and possibly frustrated, Thimelby is careful to reassure and reinforce her sisterly affection. She ends the letter urging her sister, "lets allways rit when we can and have patience when we can not so shall we be more hapy when we meeat

\footnotetext{
${ }^{200}$ These letters are undated. Thimelby professed at Louvain in 1635 and her sister Katherine died in 1658, however since only her letters from 1655 to 1689 have survived we can posit these letters were written sometime between 1655 and 1658, Van Hyning, Convent Autobiography, 46. ${ }^{201}$ Naomi J. Miller and Naomi Yavneh, "Introduction: Thicker Than Water," in Sibling Relations and Gender in the Early Modern World: Sisters, Brothers and Others, ed. by Naomi J. Miller and Naomi Yavneh (Aldershot: Ashgate, 2006), 2.

202 BL Add. MS 36 452, fol. 61.

${ }^{203}$ BL Add. MS 36 452, fol. 63.

${ }^{204}$ BL Add. MS 36 452, fol. 63.
} 
[sic] whance agen know certaynely my hart can never change to you." 205 While the lack of additional letters make any definitive conclusions on this sisterly relationship difficult, it is clear that these two women, although separated by distance, were determined to maintain their relationship and affection.

After her sister's death in 1658, Thimelby did not stop writing. Instead, she wrote consistently to her sister's husband Herbert Ashton and her various nieces and nephews. In these letters the fulfilment that Thimelby received from her correspondence is a consistent theme. For example, in one letter she wrote, "doe not suppose me a well mortifyed nun dead to the world for alas tis not so, I am alive and....as nearly concern'd for thos I love as if I had never left them." 206 This quote is remarkable for what it tells us of Thimelby's conceptualization of her role as a nun. She is acutely aware of the rhetoric surrounding the 'well mortifyed nun' while acknowledging her inability to meet this ideal. Given that women religious were meant to cut ties with their families upon profession, this strong yearning to maintain connection is telling.

Thimelby continued this theme in other letters when she wrote, "your letters feast me with delight, your sylence proves a wholsom fast" and in another, " $\mathrm{y}^{\mathrm{r}}$ corishpondence has a better relish with my appetite, then any other."207 Thimelby's use of language connected to fasting and feasting in these passages can be read as an intentional and significant choice. In her book Holy Feast, Holy Fast, Caroline Walker Bynum has argued that food was a central motif in Christianity, yet in the Middle Ages played a

\footnotetext{
205 BL Add. MS 36 452, fol. 63.

${ }^{206}$ BL Add. MS 36 452, fol. 78. This oft-cited quote was made popular by Walker's seminal article "'Doe not supose me a well mortifyed Nun dead to the world"," 159.

${ }^{207}$ BL Add. MS 36 452, fols. 98, 100.
} 
larger role in women's piety than men's. ${ }^{208}$ Fasting was also viewed as the “most painful renunciation" and eating "as the most basic and literal way of encountering God."209 Using the metaphor of a feast, Thimelby shows the nourishment she received from letters when she writes:

"I had patience to fast all lent from the lov'd dayntys of $\mathrm{y}^{\mathrm{r}}$ letters but easter brings an expectation of such feasts agen. I therfor now bring in the first corce of an ordinary homly dish tis $\mathrm{y}^{\mathrm{r}}$ torne to bring the secound upon $\mathrm{w}^{\mathrm{ch}}$ my apetit is wholy bent as sure to relish every bitt and crome that falls from that table of comfort." 210

In this passage, letters become food, an object so powerful it required the most extreme renunciation, fasting. Rather than being incompatible with religious life, Thimelby constructs her correspondence as a spiritual experience. Her use of the language of fasting and feasting highlights that she understood her letter-writing as a religious practice, or form of spiritual feeding.

Interestingly, Thimelby's niece Katherine, who would eventually join her at Louvain, seems to have inherited her aunt's love of letters. At one point, after Katherine received a letter from her father, Thimelby urged him to "rite againe for this letter is almost quit worn out with her continuall kissing itt." ${ }^{211}$ As Gary Schneider has argued, kisses were "frequently textualized in lieu of physical presence" and kissing the letter itself represented kissing the absent writer. ${ }^{212}$ Katherine's action, of kissing the letter, reinforces that "letters were regarded as precious documents to be retained after

\footnotetext{
${ }^{208}$ Caroline Walker Bynum, Holy Feast and Holy Fast: The Religious Significance of Food to Medieval Women (Berkeley: University of California Press, 1987), 4; see also chapters two and three on the historical and religious significance of food.

209 Bynum, Holy Feast and Holy Fast, 2.

${ }^{210}$ BL Add. MS 36 452, fol. 90.

${ }^{211}$ BL Add. MS 36 452, fol. 72.

${ }^{212}$ Gary Schneider, "Affecting Correspondences: Body, Behavior, and the Textualization of Emotion in Early Modern English Letters," Prose Studies 23, no. 3 (2000): 38.
} 
reading...prized for their sentimental...worth." 213 Kissing was also a spiritual practice, the most prominent religious example being the 'kiss of peace' - a Christian greeting used to reinforce "the bond of Christian fellowship." 214 Thus, what appears at first glance as a simple act of affection, was actually embedded with deep symbolism and meaning.

Thimelby's letters indicate that she was deeply affected when there was a lull in communication. Lamenting one of Herbert's long silences Thimelby wrote, “you rite sildomer now then ever, though I never wanted that satisfaction so much as now... I am no stone, kyndnis is as living in my breast as full in power as ever, cloude yours no more with sylence." 215 As Victoria Van Hyning has argued, Thimelby's letters read as a nun "trying to live according to the life she chose" but nevertheless affected by her "physical absence from family members, and unexpected silences." ${ }^{216}$ Thimelby's letters show that it was almost impossible for some nuns to cut all emotional ties to the world. In fact, Thimelby appears both aware and accepting of "her own fluid and multiple emotions," which were deeply tied to her connections outside the convent. ${ }^{217}$ For Thimelby, and other women religious, there existed a conflict "between her intentions to detest the world and her natural tendencies to cling to it despite herself." 218

It is also possible for us to move beyond the content and look at the materiality of the letters themselves to analyze Thimelby's attachment to her family. In The Material

\footnotetext{
${ }^{213}$ Caroline Franklin, "Introduction: The Material Culture of Eighteenth-Century Women's Writing," Women's Writing 21, no. 3 (2014): 287.

${ }^{214}$ Kiril Petkov, The Kiss of Peace Ritual, Self, and Society in the High and Late Medieval West (Leiden: Brill, 2003), 13-17.

${ }^{215}$ BL Add. MS 36 452, fol. 87.

${ }^{216}$ Van Hyning, Convent Autobiography, 53.

${ }^{217}$ Isobel Grundy, "Women's history? Writings by English Nuns," in Women, Writing, History, 1640-1740, ed. by Isobel Grundy and Susan Wiseman (London: B.T. Batsford Ltd., 1992), 134.

${ }^{218}$ Lux-Sterritt, English Benedictine Nuns in Exile in the Seventeenth Century, 143.
} 
Letter in Early Modern England, James Daybell has argued that examining the physical layout of letters is crucial to uncovering the "social politics of manuscript space." 219 If we consider just one example of Thimelby's letters we can understand how her use of space was vitally tied to her relationship to the letter (Fig. 1.1). In this example, written to Herbert on December $8^{\text {th }}$, Thimelby covers almost the entire paper in writing, spilling over into the margin and even continuing - upside down - on the top, barely leaving enough space for the date. Of the 34 letters preserved and examined, Thimelby continues into the margins in 27 of them. While there may be an economic rationale for this, related to the cost and availability of paper, it is possible to understand this as an active epistolary choice. ${ }^{220}$ According to Daybell, reading this use of space in relation to early modern epistolary conventions tells us that "fuller letters, which ran to more than one side, filling the entire page and continuing in the margins indicate...more emotional or sentimental reasons for writing." ${ }^{221}$ Given that Thimelby likely wrote annually to her family, we may understand this use of space as her attempt to distil as much news, concern, and guidance as possible in a small amount of space, but also as evidence of her emotional connection to the recipients.

\footnotetext{
${ }^{219}$ Daybell, The Material Letter in Early Modern England: Manuscript Letters and the Culture and Practices of Letter-Writing, 1512-1635 (New York: Palgrave Macmillan, 2012), 92.

${ }^{220}$ See Daybell's discussion of paper in The Material Letter in Early Modern England, 32-37. ${ }^{221}$ James Daybell, "Material Meanings and the Social Signs of Manuscript Letters in Early Modern England," Literature Compass 6, no. 3 (2009): 659.
} 


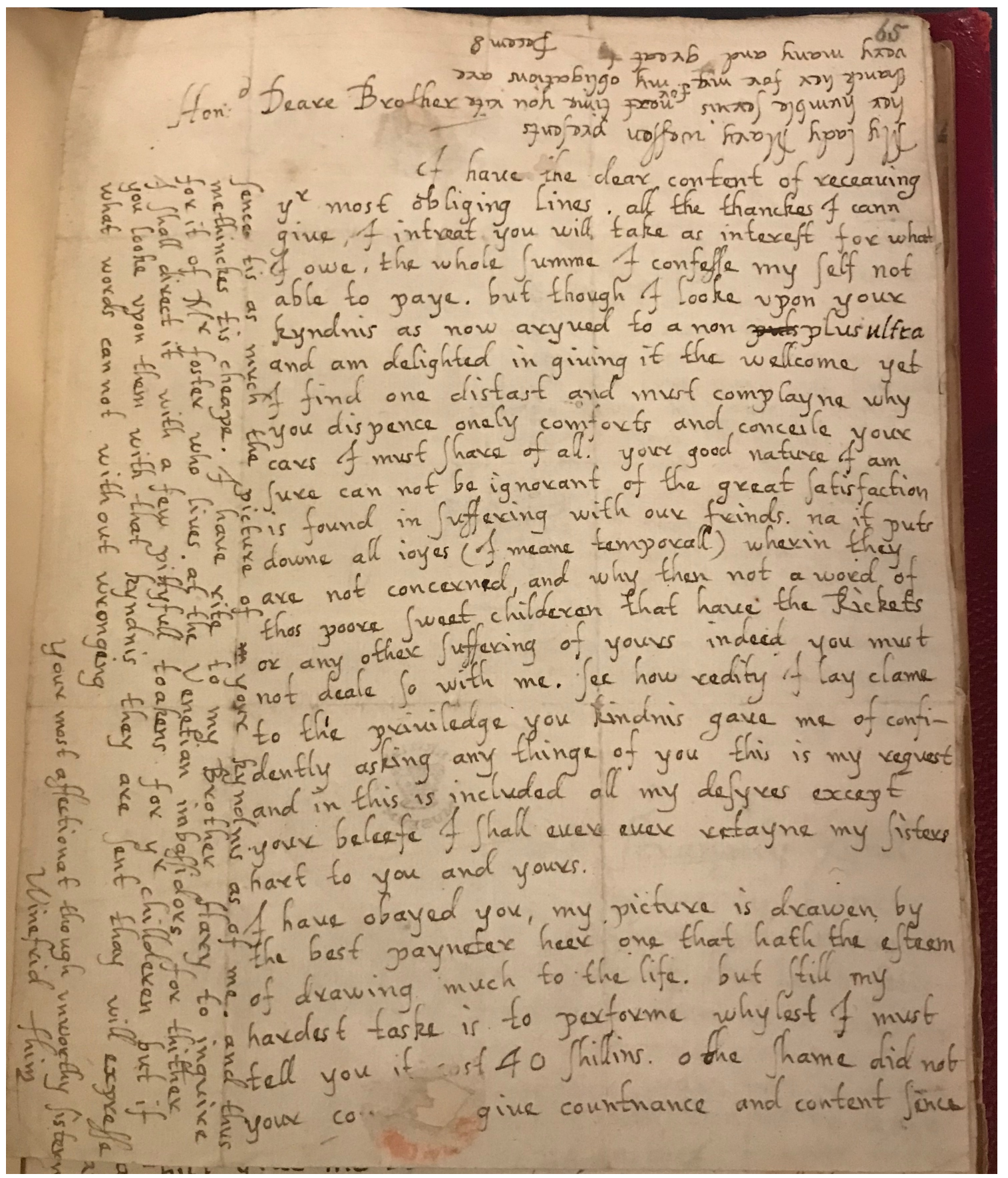

Fig. 1.1 Letter from Winefrid Thimelby to Herbert Aston, dated December $8^{\text {th }}$. British Library, Aston Papers Vol. IX, Additional MS 36 452, fol. 65 (reproduced with permission.) 
The theme of longing for correspondence, or connection, also ties to the idea of self-love that is evident in Thimelby's letters. If we think back to the notion that a nun was meant to be 'dead to the world,' our understanding of Thimelby's letters takes on a new meaning. As a cloistered nun, Thimelby was expected to leave everything behind, including attachment to herself or anyone else. ${ }^{222}$ For women religious in general, there was an emphasis placed on "the absence of self-love or pride," one document from Cambrai even "compared the nuns' lives to a spiritual martyrdom." 223 And yet, the evidence from Thimelby's letters shows that a complete separation and devaluation of self or emotions was difficult to achieve. In May 1686, near the end of her life, she wrote to Herbert: "I speake my shame at discovering my self love...in hearing from you, in circumstances that shuld render mee busied with nothing but preparation for death." 224 Far from repressing feelings of love and affection for her family, Thimelby obviously struggled, likely to her own frustration, to achieve the idealistic standards of a 'perfect' nun. And Thimelby was certainly not alone. Rather, we can assume that "many nuns struggled to reconcile what they really did feel with what they knew they should feel."225 This highlights the tension that existed in convents between rhetoric and reality.

Recruitment is another noticeable theme in Winefrid Thimelby's letters. Thimelby continuously asked her brother-in-law to send his daughters to her, in one instance writing, "I shall importunely begg you will give me one." ${ }^{226}$ In another letter she enquires about his daughter Katherine's health and states, "I shuld conceive it my duty to wooe for

\footnotetext{
${ }^{222}$ Lux-Sterritt, English Benedictine Nuns in Exile in the Seventeenth Century, 28.

${ }^{223}$ Lux-Sterritt, English Benedictine Nuns in Exile in the Seventeenth Century, 35-36.

${ }^{224}$ BL Add. MS 36 452, fol. 107.

${ }^{225}$ Lux-Sterritt, English Benedictine Nuns in Exile in the Seventeenth Century, 139.

${ }^{226}$ BL Add. MS 36 452, fol. 61.
} 
the best child." 227 Thimelby's letters were partially successful, since both Katharine (also known as Keat) and Gertrude Aston did end up at St. Monica's in the 1660s. While Katherine would profess in 1668, Gertrude, despite pressure from Thimelby, decided not to pursue a religious vocation. ${ }^{228}$ Multiple letters from Thimelby highlight her disappointment at Gertrude's decision, and she even continued her epistolary recruitment efforts for a time. Nicky Hallett observed that Thimelby utilized maternal imagery and analogy in order to "entice her [niece Gertrude] to join the community." 229 Hallett refers specifically to a passage from a February 1672 letter:

"perhaps god deals with thee as my mother did with me when a litle foolish child, and nuely weaned from the brest, I gott a trick to suck my thum, but she so rubd it with worm wood I quickly left that sport, so I phansy allty god sprinkels with bitternis all thy lou'd pleasures and will not haue thee suck dry broken cesterns but drink full draughts at the fountayne head of true and lasting ioys such as flow in religion." 230

Thimelby did not stop writing once she realized that Gertrude did not share the same desire for monastic life; instead, she continued to be engaged in Gertrude's secular life. In one letter, Thimelby tempered her ambitions for Gertrude, writing, "I meane not to seale thee up in a clouster...but I mean to seale thee up to his own service." ${ }^{231}$ In her next letter she continued this idea and wrote, "my hart is so topfull of desyre to have thee as hapy $[a s]$ my self but I wod not have thee take it for perswation." ${ }^{232}$ In other words, although

\footnotetext{
${ }^{227}$ BL Add. MS 36 452, fol. 66. See also the entry for Catherine Aston (LA008) in WWTN $<$ https://wwtn.history.qmul.ac.uk $>$ [accessed Nov 11 2019].

${ }^{228}$ Walker, "'Doe not supose me a well mortifyed Nun dead to the world'," 170.

${ }^{229}$ Nicky Hallett, "Paradise Postponed: The Nationhood of Nuns in the 1670s," in Religion, Culture and the National Community in the 1670s, ed. by T. Claydon and T. Corns (Cardiff: University of Wales Press, 2011), 20.

${ }^{230}$ Hallett, "Paradise Postponed," 20. Original found in BL Add. MS 36 452, fol. 93.

${ }^{231}$ BL Add. MS 36 452, fol. 92.

${ }^{232}$ BL Add. MS 36 452, fol. 93.
} 
Thimelby would ideally see her niece become a nun she appears content for Gertrude to maintain and preserve the Catholic faith as a laywoman.

And yet, Thimelby still seems to have struggled with Gertrude's decision.

Addressing her own lack of letters she wrote, "I fynd it hard to speake to thee and not to speake the bottom of my hart, and that agayne might troble thee because our dissyres differ." ${ }^{233}$ This passage is noteworthy for what it reveals about Thimelby's own feelings toward monasticism. As Claire Walker has argued, “despite...[Thimelby’s] obvious attachment to the world, her letters consistently enunciated an overwhelming satisfaction with her monastic life." 234 Thus it is not hard to understand why she tried to pass this same enthusiasm on to the next generation. This also lends credence to the idea that Thimelby did not use her letters to rebel against the idea of enclosure or her monastic life, but rather understood the two to be in some way compatible. Thimelby's letters highlight the multifaceted nature of women religious' correspondence. Letters functioned as a form of spiritual service, to "bring her loved ones closer to God," but they also worked to benefit her own convent's survival and recruitment. ${ }^{235}$

Another significant theme in Thimelby's letters is being reunited in death with the family she was physically removed from. In one letter to her sister, Thimelby remarks:

"it is my dayly comfort to remember how fast we approach each other: \& that every moment dispatches some part of the way, this makes me content with present absence... really Sister you cannot imagin how much the memory of you gives increase of very solid joys... you must give me leave to love our seperation because it helps to secure an eternall mutuall injoying." 236

\footnotetext{
${ }^{233}$ BL Add. MS 36 452, fol. 94.

${ }^{234}$ Walker, "'Doe not supose me a well mortifyed Nun dead to the world"," 169.

${ }^{235}$ Walker, "'Doe not supose me a well mortifyed Nun dead to the world'," 169.

${ }^{236}$ BL Add. MS 36 452, fol. 61-62.
} 
In another letter she laments her good health because it "delayes my meeting with my Sister franck." ${ }^{237}$ In her letters to her brother-in-law, Thimelby makes several references to her impatience with death and their eventual reuniting. For example, she writes, "Ile steale som glimes of comfort by remembering we are both walking towards each other and certaynely shall meet att last sence every houre dispatches part of our way...every houre brings the good newes of our aproach to death." 238 Thimelby's understanding of and relationship to death is extremely interesting. When informing her nieces of their sister Katherine's death, Thimelby wrote, “you must not think your Sister Keat is dead though my joys bee so, she truely lives and shall never dy, she laughs at our fond tears for god has wyp'd her eyes." ${ }^{239}$ It could be argued that Thimelby approaches death with what Isobel Grundy has called "slightly disturbing high spirits," which can be traced back to her strong Catholic beliefs. ${ }^{240}$ But these passages underscore the idea that Thimelby "drew solace from the prospect of spending eternity with her beloved relations." ${ }^{241}$ In her final few letters, Thimelby attempted to break, or lessen, her family's attachment to her, and vice versa. She wrote, "I confess twas my designe to wean both my self and you from that satisfaction [of letters] for now my age tells me I have no long to live" but then continues, "yet if a letter com from you I owne t'will be a pleasant distraction and I will be sure to give you another." 242 The power of letters in a convent context is clear. As Victoria Van Hyning has succinctly stated, "so precious are these documents to all

\footnotetext{
${ }^{237}$ BL Add. MS 36 452, fol. 63. Here Thimelby is referring to her sister Frances who was also an Augustinian nun at Louvain and died April 21, 1644, see entry for Frances Thimelby (LA260) in WWTN <https://wwtn.history.qmul.ac.uk $>$ [accessed Nov 11 2019].

${ }^{238}$ BL Add. MS 36 452, fol. 87.

${ }^{239}$ BL Add. MS 36 452, fol. 104.

${ }^{240}$ Grundy, "Women's history? Writings by English Nuns," 135.

${ }^{241}$ Walker, "'Doe not supose me a well mortifyed Nun dead to the world'," 169.

${ }^{242}$ BL Add. MS 36 452, fol. 103.
} 
concerned that they must 'wean' themselves from the pleasure of letters." ${ }^{243}$ Despite Thimelby's efforts to distance herself from her family, the continuation of her letter writing shows that this was never fully achieved.

Thimelby's letters are filled with an emotion and affection not seen in the familial letters of other women religious. However, they also underscore her own faith, and her desire to see the continuation of her family's faith back in England. Letters provided women religious with a medium to psychologically breach enclosure and remain connected to their former secular lives and families. ${ }^{244}$ But Thimelby was able to construct her letters in a way that was compatible with her religious identity. Her letters can be viewed both as a form of spiritual service as well as a tool to benefit her convent.

\section{"The troble of my frequent letters": The Caryll Correspondence}

While Thimelby's letters are unique for their tone and content, she was not the only nun to maintain familial contact through letters. Another women religious who sustained significant contact with her family was Mary Caryll. ${ }^{245}$ She professed with the Ghent Benedictines in 1650 at age 19, and in 1662 she left to help found a sister house in Dunkirk, where she was elected abbess in $1663 .{ }^{246}$ She remained abbess until her death in 1712. ${ }^{247}$ During her time as a nun, her most frequent contact was her brother, John Caryll, who was prominent in the English exile scene. John was secretary to Queen Mary of Modena, the wife of the deposed King James II - who gave him the title of Baron Caryll

\footnotetext{
${ }^{243}$ Van Hyning, Convent Autobiography, 80.

${ }^{244}$ Walker, "Doe not supose me a well mortifyed Nun dead to the world'," 167.

${ }^{245}$ These letters can be found at the British Library, Correspondence of Lord Caryll, Secretary to Queen Mary of Modena, 1648-1711, Additional MS 28226.

${ }^{246}$ Walker, "Doe not supose me a well mortifyed Nun dead to the world'," 165 . See also the entry for Mary Caryll (GB040) in WWTN <https://wwtn.history.qmul.ac.uk> [accessed Nov 13 2019].

${ }^{247}$ Walker, "'Doe not supose me a well mortifyed Nun dead to the world"," 165.
} 
of Durford in 1698 - and he followed the royal family into exile in Saint-Germain, France. ${ }^{248}$ Although he experienced financial difficulty as a result of his politics, he continued to be an important patron of his sister's convent, as evidenced by their letters, until his death in $1711 .{ }^{249}$ Notably, two letters from John to Mary have been preserved, which allow us a glimpse into the other side of the conversation. As we will see, Mary Caryll utilized letter writing as a tool not only to secure her convent's economic survival, but also to maintain her own personal connection to the secular world.

The Caryll family had a strong presence in the English convents in exile scene. A quick glance at Mary Caryll's profile on the WWTN database shows that five of her sisters, and numerous nieces, great nieces and cousins, were also professed nuns at English convents. ${ }^{250}$ This strong conventual presence was not unique. Statistics from the seventeenth century show that an estimated 60 percent of English nuns had one or more relative who was also in a convent. ${ }^{251}$ This reveals that familial bonds were not only emotionally, but also physically sustained. It also lends authority to the idea that letters would be key for maintaining the networks that supported familial recruitment.

At its most fundamental level, recruitment had an economic rationale for convents. New recruits meant an influx of money (through dowries) and thus economic security. ${ }^{252}$

\footnotetext{
${ }^{248}$ Claire Walker, "Recusants, Daughters and Sisters in Christ: English Nuns and their Communities in the Seventeenth Century," in Women, Identities and Communities in Early Modern Europe, ed. by Stephanie Tarbin and Susan Broomhall (Aldershot: Ashgate, 2008), 69; Howard Erskine-Hill, "Caryll, John, Jacobite first Baron Caryll of Durford," in Oxford Dictionary of National Biography. 23 Sep. 2004. https://doi.org/10.1093/ref:odnb/4847

${ }^{249}$ Walker, "'Doe not supose me a well mortifyed Nun dead to the world'," 166; Erskine-Hill, "Caryll, John, Jacobite first Baron Caryll of Durford," https://doi.org/10.1093/ref:odnb/4847

${ }^{250}$ See also the entry for Mary Caryll (GB040) in WWTN for references to family members $<$ https://wwtn.history.qmul.ac.uk> [accessed Nov 26 2019].

${ }^{251}$ Lux-Sterritt, English Benedictine Nuns in Exile in the Seventeenth Century, 60.

${ }^{252}$ Bowden, "Patronage and Practice," 487; Walker, Gender and Politics in Early Modern Europe, 79.
} 
Stable recruitment numbers were also an indicator of a convents' good reputation and attractiveness to benefactors. ${ }^{253}$ Letter writing was therefore necessary for practical, material reasons, that in turn ensured spiritual prosperity. However, as Winefrid Thimelby's letters indicated, recruitment did not always go smoothly. In one letter from 1700, Mary Caryll remarks on the trouble her niece Barbara was undergoing during her attempt at profession in Bruges. Caryll comments:

I send you the $\mathrm{R}^{\mathrm{d}}$ Mothers letter I had this morning, which dus a litle surprise me, she seemes to judg $\mathrm{M}^{\mathrm{rs}}$ Barbara is not fitt for a Religious life...my care is, how you will dispose of her, for I think unless you help her, she has not soe good a portion as her sister Anne, nor has she such quallitys to help her self." 254

While it is not clear from the remaining letters what happened to Barbara, this exchange is telling. Not only does this passage provide evidence of inter-convent communication or rather, correspondence between nuns from different convents and orders, a type of communication often not preserved. It also shows the precarious nature of family recruitment. In fact, even though Winefrid Thimelby greatly desired her niece's profession, she was forced to admit in one letter that, "in spyt of all selfe interist, no person is admitted but by the votes of all the Conventualls who must know what meanes thay have and accordingly refuse or receive them. ${ }^{255}$ In other words, as much as her own self-interest would see the recruitment of her nieces, Thimelby acknowledges that she did not hold all the power to make that decision and that it would ultimately have to benefit her convent. Sometimes convents had to prioritize their own survival over the desires of, or their own personal hopes for, their natal families.

${ }^{253}$ Bowden, "Missing Members," 56.

${ }^{254}$ BL Add. MS 28 226, fol. 120.

${ }^{255}$ BL Add. MS 36 452, fol. 89. 
Unlike Winefrid Thimelby, whose letters are almost completely devoid of concerns outside her family and convent, Mary Caryll was invested in affairs back in England and continental activities. She was particularly concerned with the situation of the exiled royal family and the king's restoration. In fact, Caryll was acutely aware of her brother's influential position at the exiled royal court. In 1688, she sent along her prayers and hopes for a male heir for the queen, Mary of Modena, who was pregnant. ${ }^{256}$ In multiple letters, she prompted her brother to send her convent's "most humble dutys and profound respects" to the queen. ${ }^{257}$ While it was not unusual for communication between convents and royalty to exist, it is important to note that these epistolary exchanges were purposeful and meant to advance each party's interests, spiritual and monetary. ${ }^{258}$ Beyond royal connections, Caryll's letters highlight her knowledge of continental political affairs. In one letter, she remarks that she hoped "that these victorys the French have every wher the begining of this Campaigne, may contribute at last to our Kings restoration." 259 The conflict between England and the continent would have also had a profound effect on the Caryll family, no doubt because it would have placed Caryll's convent in a precarious financial position. In February 1706 she wrote, "England is soe

\footnotetext{
${ }^{256}$ BL Add. MS 28 226, fol. 112. Caryll's hopes for a male heir would be realized when the queen gave birth to a son James Francis Edward Stuart. For more on James Stuart see Edward Gregg, "James Francis Edward [James Francis Edward Stuart; styled James; known as Chevalier de St George, the Pretender, the Old Pretender] (1688-1766), Jacobite claimant to the thrones of England, Scotland, and Ireland," Oxford Dictionary of National Biography. 24 May 2012. https://doi.org/10.1093/ref:odnb/14594

${ }^{257}$ BL Add. MS 28 226, fol. 116. For an examination of Mary of Modena's patronage of English convents, and the reciprocal nature of their relationship, see Claire Walker, "Loyal and Dutiful Subjects: English Nuns and Stuart Politics," in Women and Politics in Early Modern England, 1450-1700, ed. by James Daybell (Burlington, VT: Ashgate, 2004), 228-241.

${ }^{258}$ Lux-Sterritt, English Benedictine Nuns in Exile in the Seventeenth Century, 124-125.

${ }^{259}$ BL Add. MS 28 226, fol. 129. In another letter Caryll writes, "God preserve our King and Queen, we have not a double interest to pray fervently for his $\mathrm{Ma}^{\text {stys }}$ Restoration," BL Add. MS 28 226, fol. 127.
} 
drain'd by these wars, and still Catholic's goes by the worst." 260 These events would have been concerning to women religious since the war created financial difficulty which meant many patrons could not continue their support or repay their debts to the convents. ${ }^{261}$ Thus Caryll's interest and concern for affairs outside her convent, despite the ideal of separation, was justified. Overall, Caryll was in no way "ignorant of politics, nor cut off from the networks of power," but rather, through her letters, took an active role in seeking out news and positioning her convent among influential networks. ${ }^{262}$

A theme that is ever present in Mary Caryll's letters is her tenacity in regard to her financial and economic situation. Claire Walker has stated that, "the most common monastic business centered upon the recruitment of novices, negotiations regarding their portion, and payment of the agreed sum," all of which were essentially left to the nuns to ensure. ${ }^{263}$ Laurence Lux-Sterritt has argued, further, that "nuns had to nourish close links with their recusant patrons at home; through correspondence, and with the help of agents who acted as go-betweens."264 However, many monastic communities had specific rules against the involvement of family in monastery business. ${ }^{265}$ And yet, in multiple letters, Mary Caryll called upon her brother to act as an intermediary for the convent, especially in regard to unpaid portions and debts. In 1688, Caryll wrote to her brother, "I must now mind you to call upon Mr Thornton, for the time draws neare, it being att Mdsomer he is to pay his youngest sisters portion."266 The necessity of these connections are evidence of

\footnotetext{
${ }^{260}$ BL Add. MS 28 226, fol. 127.

${ }^{261}$ Lux-Sterritt, English Benedictine Nuns in Exile in the Seventeenth Century, 84.

${ }^{262}$ Lux-Sterritt, English Benedictine Nuns in Exile in the Seventeenth Century, 124.

${ }^{263}$ Walker, "'Doe not supose me a well mortifyed Nun dead to the world'," 163.

${ }^{264}$ Lux-Sterritt, English Benedictine Nuns in Exile in the Seventeenth Century, 88.

${ }^{265}$ Walker, "Recusants, Daughters and Sisters in Christ," 65.

${ }^{266}$ BL Add. MS 28 226, fol. 112.
} 
the disconnect between rhetoric and experience in religious houses. In a later letter, Caryll acknowledged her brother's success at recouping payments when she remarked, "if all such mistakes fell into your hands, ther would be noe daunger of banckaroupt."267 The bond between brothers and sisters was particularly important in the convent context because these relationships "outlasted parental ones, often by decades."268 Men also had stronger political and economic connections that could be utilized by their cloistered relatives. ${ }^{269}$ In this case, the collection of debts was obviously a concern for Caryll, but with correspondence as her tool she was able to utilize her relationship with her brother to her advantage. ${ }^{270}$

Apart from financial matters, John Caryll also acted as an important intermediary for the convent because of his relationship to the exiled royal court. For example, when it was proposed that the Dunkirk convent merge with the financially struggling Benedictine convent at Ypres, Mary Caryll expressed her opposition. ${ }^{271}$ Subsequently, John persuaded Mary of Modena to stop the merger and keep the convents separate. ${ }^{272}$ While this example may appear to indicate a one-sided relationship with Mary as the main beneficiary, her interactions with John were mutually beneficial. John assisted Mary with convent business, and in return, Mary and her community prayed for his health and

\footnotetext{
${ }^{267}$ BL Add. MS 28 226, fol. 114.

${ }^{268}$ Craig A. Monson, "Families, Convents, Music: The Power of Sisterhood," in Sibling Relations and Gender in the Early Modern World: Sisters, Brothers and Others, ed. by Naomi J. Miller and Naomi Yavneh (Aldershot: Ashgate, 2006), 46; Bernard Capp, The Ties that Bind: Siblings, Family, and Society in Early Modern England (Oxford: Oxford University Press, 2018), 123.

${ }^{269}$ Craig A. Monson, "Families, Convents, Music," 46.

${ }^{270}$ Walker, "'Doe not supose me a well mortifyed Nun dead to the world'," 166.

${ }^{271}$ BL Add. MS 28 226, fol. 116; Caroline Watkinson, "Engaging Nuns: Exiled English Convents and the Politics of Exclusion, 1590-1829," (PhD diss., University of Westminster, 2016), 126; Claire Walker, "Loyal and Dutiful Subjects," 234.

${ }^{272}$ Caroline Watkinson, "Engaging Nuns," 126
} 
longevity. After averting the Dunkirk and Ypres merger Mary writes, that she prays God "reward you [John], with health and long life, which is the dayly prayer of this community." 273 This spiritual activity was not unique to Mary Caryll. Other convents expected women religious to provide spiritual alms and prayers to those who provided temporal relief to the community. ${ }^{274}$ In fact, this type of reciprocity was central to contemplative monastic communities, whose members devoted themselves to hours of prayer for their patrons and benefactors, who were otherwise preoccupied with worldly affairs. ${ }^{275}$ Rules were even developed to detail the spiritual payment required for different acts of temporal assistance. ${ }^{276}$ In this way, the offering of opening and closing prayers, as well as blessings through letters, can be situated on a spectrum of ritual spiritual service. Letters provided a medium for nuns to readily exchange spiritual favours for worldly ones in return. For example, after John made a donation to the convent Mary wrote to him, "my Community [is] soe penetrated with gratitude...for your bounty to us, and with pleasure...they have made the...vows and prayers, which if it be Gods will may lenthen your days in this life and soone get you out of purgatory." 277 In another sense, letters provide 'proof' of the prayers in exchange for money or other material favours. In this way, the Caryll siblings' relationship worked to provide Mary with convent security and John with spiritual security.

\footnotetext{
${ }^{273}$ BL Add. MS 28 226, fols. 116.

${ }^{274}$ Claire Walker, "Combining Martha and Mary: Gender and Work in Seventeenth-Century English Cloisters," The Sixteenth Century Journal 30, no. 2 (1999): 405-406.

${ }^{275}$ From the Medieval ages (continuing into the early modern period) nuns and monks were expected to pray for those who "endowed their communities with lands and goods, and... who continued to provide alms," Walker, Gender and Politics in Early Modern Europe, 87.

${ }^{276}$ Walker, Gender and Politics in Early Modern Europe, 88-89.

${ }^{277}$ BL Add. MS 28 226, fol. 124.
} 
Beyond her concerns for the royal family and her community, Mary Caryll was deeply interested in the activities for her own natal family. She inquires multiple times to her brother about his health and the lives of various nieces and nephews. In one letter she writes, "I am a litle curious to inquire how you find affaires as to your owne estate, and whether my Nephu thrives in the world." ${ }^{278}$ In 1706, we have evidence of one back and forth exchange between John and Mary. In her letter, Mary relates the news of their nephew Phill's son, who intended to join the French Guard Marine, but who still wanted the money John had promised for his upkeep at the English college of St. Omers. ${ }^{279}$ John responded to his sister's letter, saying that he would not "allow him a penny tords his maintenance unless it be at St Omers, or in some college where he may be bred a Christian." ${ }^{280}$ This exchange highlights the centrality of Christianity to the Caryll siblings, with John only willing to financially support his relative if it contributed to the preservation of their Catholic faith. It is also interesting here that, just as John acts as an intermediary for Mary's financial matters, Mary acts as John's intermediary for family matters. This again highlights the reciprocal nature of the Caryll siblings relationship and the power of letters to maintain these bonds.

Although their letters lack the metaphoric, flowery and affectionate language of the Aston-Thimelby family correspondence, the Caryll letters offer an alternative perspective through which to view familial relations during the late seventeenth and early eighteenth century. As Bernard Capp argues, in the early modern period "girls were brought up...to subordinate their own interests to those of their elder brothers and the lineal family."281

\footnotetext{
${ }^{278}$ BL Add. MS 28 226, fol. 113.

${ }^{279}$ BL Add. MS 28 226, fol. 124.

${ }^{280}$ BL Add. MS 28 226, fol. 126.

${ }^{281}$ Capp, The Ties that Bind: Siblings, Family, and Society in Early Modern, 61.
} 
And yet analysis of the Caryll letters shows that the relationship between Mary and John was much more dynamic. Mary did not shy away from her own interests, even if she pursued them tactically. Through her letters we can see that, although Mary "relied upon John to help her with the material management of dowries and other patronage, she also learnt much about current affairs through her correspondence with him."282 In this way, none of the Caryll letters served only one purpose.

It is also interesting to note that, in Caryll's correspondence with her brother, she ends each letter using her birth name, 'Mary Caryll' not her religious name, which was 'Mary Teresa'. This is notable since, as Laurence Lux-Sterrit has argued, a “nun's new name in religion...symbolized the death of her secular being," which is connected to the larger goal of being 'dead to the world'. ${ }^{283}$ One might therefore read Mary's epistolary choice, coupled with the content of her tireless correspondence, as evidence that her secular identity was never truly forgotten. The use of this name when corresponding with John, may have also worked to "reaffirm their fraternal bond... [which] demonstrates the importance she gave to their blood kinship." 284 It is clear that John and Mary, although physically separated, remained very close. In one of her final letters to John, Mary remarks that, despite her failing health and other correspondents, "yours is the only letter I can put my pen too." ${ }^{285}$ While her correspondence with John certainly had practical, financial, advantages for Mary, we would be remiss if we underestimated the familial connection and concern that persisted between the two siblings.

\footnotetext{
${ }^{282}$ Lux-Sterritt, English Benedictine Nuns in Exile in the Seventeenth Century, 112. ${ }^{283}$ Lux-Sterritt, English Benedictine Nuns in Exile in the Seventeenth Century, 35.

${ }^{284}$ Lux-Sterritt, English Benedictine Nuns in Exile in the Seventeenth Century, 163.

${ }^{285}$ BL Add. MS 28 226, fol. 140.
} 
Not only did Mary Caryll inquire into family concerns, she also actively passed along news and letters, implying that her brother was by far not her only familial correspondent. In a letter to her brother, she recounts correspondence that she received from their nephew, who was suffering from an illness that she feared "may have hindered his studys. ${ }^{286}$ Further, while passing along a bleak letter from her niece in England, Caryll remarks, "I could half wish I might not pertake, of the recitall of theyr miseryes, since tis not in my powre to doe more than pray for them." ${ }^{287}$ Here Caryll acknowledges, at least subtly, the limitations of her position within a convent. Similar to Winefrid Thimelby, Mary Caryll recognized that her concerns transcended the enclosure. In 1706 she commented, "you may justly reproach me, to have these conserns out of the inclosier" but follows up that "I hope God will pardon me, my intention being only that our fammillys may propogate Religion, and be serviable to theyr King." ${ }^{288}$ Similar to Thimelby, breaking enclosure through letters appears to be justified based on the benefit the correspondence was intended to yield.

Overall, the letters of Mary Caryll allows us insight into the ways that familial correspondence and convent management were interconnected. As Claire Walker has argued, "many cloisters could not afford the luxury of insularity." ${ }^{289}$ Caryll's letters are evidence of the necessity of engaging with the secular world. Her letters highlight that she was deeply concerned with securing her convent's financial security, and position within influential royal networks. But she also remained greatly invested in, and attached to, the activities and lives of her relations outside the convent. Caryll's letters prove that

\footnotetext{
${ }^{286}$ BL Add. MS 28 226, fol. 114.

${ }^{287}$ BL Add. MS 28 226, fol. 128.

${ }^{288}$ BL Add. MS 28 226, fol. 127.

${ }^{289}$ Walker, "Recusants, Daughters and Sisters in Christ," 68.
} 
letter writing went far beyond practical matters and worked to maintain a nun's familial connections and secular concerns.

\section{Family Connections across the Ocean: The Hagan Sisters}

"Excuse the curiosty of nuns," wrote Monica Hagan, from her convent in Rouen, to Father John Bolton, a priest in Maryland, in the late eighteenth century. ${ }^{290}$ The word 'curious' highlights the idea that letters allowed nuns to engage with news and information in a way that was outside the norm of religious behaviour. Unlike the correspondence of Winefrid Thimelby and Mary Caryll, who both wrote to relatives, the letters of the Hagan Sisters are mostly written to a third, non-familial party. Although one letter between the sisters themselves has been preserved. The Hagan correspondence, perhaps due its limited scale, has not received the scholarly attention that other letters of women religious have. ${ }^{291}$ However, its value should not be underestimated. Letters allowed the Hagan sisters to maintain transnational connections with contacts in America, such as Father John Bolton in Port Tobacoo, Maryland, but also with each other across convent walls. ${ }^{292}$ Two of the four Hagan Sisters, Elizabeth Clare and Monica Clare, were professed together at the Poor Clares convent in Rouen, France in 1763, after travelling to

\footnotetext{
${ }^{290}$ Monica Clare Hagan to Father John Bolton, June 10 1785, in, "Connections Between Europe and America Before Independence," in English Convents in Exile, 1600-1800: Volume 6. The Convents and the Outside World, ed. by Carmen M. Mangion, Michael Questier, Emma Major and Caroline Bowden (London: Pickering \& Chatto, 2012), 151.

${ }^{291}$ Edited transcriptions of these letters have been produced in Volume 3 and Volume 6 of English Convents in Exile but with only a brief (one page) contextualization provided by Caroline Bowden. The letters themselves have not been critically analyzed.

${ }^{292}$ Caroline Bowden, "Connections Between Europe and America Before Independence," in English Convents in Exile, 1600-1800: Volume 6. The Convents and the Outside World, ed. by Carmen M. Mangion, Michael Questier, Emma Major and Caroline Bowden (London: Pickering $\&$ Chatto, 2012), 143. For more on convent connections between Europe and America see Charles Warren Currier, Carmel in America: A Centennial History of the Discalced Carmelites in the United States (Baltimore: J. Murphy \& co, 1890); Nicky Hallett, "Paradise Postponed," 1034; and James E. Kelly, "Jesuit News Networks and Catholic Identity," 337-360.
} 
the continent from their home in Maryland, United States. ${ }^{293}$ The other two sisters, Henrietta Hagan, known in religion as Teresa, and Mary Louisa Hagan professed with the Benedictines at Paris and Cambrai, respectively, in $1760 .^{294}$ Their correspondence serves to demonstrate that letters allowed nuns, and their families, to transcend physical distance and maintain significant global connections. ${ }^{295}$

Similar to the correspondence of Winefrid Thimelby and Mary Caryll, the Hagan letters reveal a deep concern for their natal family back in America. In one letter, Elizabeth and Monica wrote to Father Bolton that, "it would be a great comfort to hear our Sister Coomes is good" and to let their friends in Maryland know that "we have not forgot them, tho it seems they have us." ${ }^{296}$ This last passage is reminiscent of the frustration Winefrid Thimelby displayed when there was a lack of correspondence. Father Bolton appears to have been a key conduit in the flow of information among members of the Hagan family. In a letter from Teresa to Bolton, for instance, she thanked him "for being so good in giving me an account of the family of which I should have very little news where it not for your obliging letters." ${ }^{297}$ In the Hagan sisters' letters, we can also

\footnotetext{
${ }^{293}$ See the entry for Elizabeth Clare Hagan (RP080) and Monica Clare Hagan (RP081) in WWTN $<$ https://wwtn.history.qmul.ac.uk $>$ [accessed Feb 25 2020]. Maryland had an interesting relationship with Catholicism, similar to England, for much of the eighteenth-century Catholics where subject to oppressive laws and restrictions on their religious freedom. Because of this, some Catholic Americans, especially from Maryland, sent their children to Europe for religious education. For an overview see Caroline Bowden, "American Connections" in English Convents in Exile, 1600-1800: Volume 6. The Convents and the Outside World, ed. by Carmen M. Mangion, Michael Questier, Emma Major and Caroline Bowden (London: Pickering \& Chatto, 2012), 139.

${ }^{294}$ Henrietta Teresa Hagan (PB036) and Louisa Mary Hagan (CB083) in WWTN $<$ https://wwtn.history.qmul.ac.uk> [accessed Feb 25 2020].

${ }^{295}$ Caroline Bowden, "American Connections," in English Convents in Exile, 6:139.

${ }^{296}$ Elizabeth Clare Hagan and Monica Clare Hagan to Father John Bolton, 27 June 1773, in English Convents in Exile, 6:145. This same sentiment is displayed in another letter from 1783, when the sisters write, "hope we shall now hear more frequently from you all," 147.

${ }^{297}$ Teresa Hagan to Father John Bolton, 15 January 1785, in English Convents in Exile, 6:148.
} 
see an overlap between concern for family affairs and spiritual, or conventual, interests. When discussing the possible entrance of their niece Monica, living in Maryland, to a convent in Europe, the aunts urged caution, since it was a "very long and expensive journey to make with out we see a solid prospect of her doing well; thats to say being called to a Religious state. ${ }^{298}$ One can read this concern as two-fold. The aunts are clearly aware of the impact this choice would have on their natal family, both economically and emotionally, but also on their convent. While a new recruit could be a source of income, she could also bring hardship and conflict if she lacked vocation. Similar to Mary Caryll's correspondence, this exchange highlights the fact that letters had to bridge an important gap between conventual and familial responsibilities. And, in fact, Monica did not ultimately profess at any convent, to which her aunt Teresa remarked, "I was not the least surprised." 299 When Monica Hagan learned that another family member, a nephew, was planning on selling his land, travelling to Europe and joining a male religious order, she again urged caution, claiming, "many a one has a pious desire of

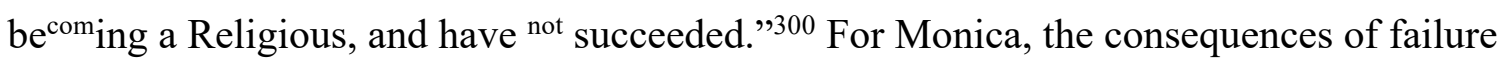
in this case would leave her nephew "in such a deprave condition" and open him up to “dangerous consequences that might ensue." ${ }^{301}$ Therefore, concern for their biological family’s physical and spiritual well-being was a key factor driving the Hagan family’s epistolary activity.

\footnotetext{
${ }^{298}$ Elizabeth Clare Hagan and Monica Clare Hagan to Father John Bolton, 11 February 1783, in English Convents in Exile, 6:147.

${ }^{299}$ Teresa Hagan to Father John Bolton, 15 January 1785, in English Convents in Exile, 6:148149.

${ }^{300}$ Monica Clare Hagan to Father John Bolton, 10 June 1785, in English Convents in Exile, 6:150.

${ }^{301}$ Monica Clare Hagan to Father John Bolton, 10 June 1785, in English Convents in Exile, 6:150-151.
} 
What makes the Hagan sisters correspondence even more remarkable is the evidence they provide of inter-convent communication. In one letter from Elizabeth and Monica to Father Bolton, the sisters wrote, "please tell all friends that our Sister Theresa at Paris is well and desire[s] to be kindly remembered...she says she does not think of writing this year. For our Sister at Cambray we have not heard of her for some time, but hope she is well." ${ }^{302}$ Further, Teresa sheds light on the sister's interaction when she writes, "I have a very great comfort in all three \& many a merry letter passes between us." $" 303$ These passages indicate that the four sisters were in contact and exchanged letters, if not regularly then intermittently, in a way that allowed them to keep updated on their lives.

But for more than just hints buried in the lines of letters to Father Bolton, we can turn to the letter that has been preserved from Mary Louisa to Teresa. The point of this letter, as Mary Louisa clearly outlines, is to "tell you some good news to comfort your poor heart, I have heard of our absent friends, I shall with pleasure inform you of all I can." ${ }^{304}$ Mary Louisa goes on to relay news, she received via letters regarding the foundation of the Carmelite convent in Maryland, the sisters' hometown. While the content of the letter is rather ordinary, the fact that this type of correspondence existed is significant. It suggests that, rather than forgoing biological sisterhood in favour of spiritual sisterhood, women religious saw value in maintaining bonds with their natal

\footnotetext{
${ }^{302}$ Elizabeth Clare and Monica Clare Hagan to Father John Bolton, 27 June 1773, in English Convents in Exile, 6:146.

${ }^{303}$ Teresa Hagan to Father John Bolton, 18 January 1786, in English Convents in Exile, 6:153. ${ }^{304}$ Mary Louisa Clare to her sister in Paris, March 26 1791, in, "Letter of Mary Louisa Hagan," in English Convents in Exile, 1600-1800: Volume 6. The Convents and the Outside World, ed. by Carmen M. Mangion, Michael Questier, Emma Major and Caroline Bowden (London: Pickering \& Chatto, 2012), 281.
} 
families. ${ }^{305}$ Additionally, Mary Louisa ended her letter by requesting that Teresa, "be so kind as to send this to our sisters when you have read it." ${ }^{" 306}$ This remark indicates that this letter was not meant to stop with Teresa, but rather be passed on to keep the other Hagan sisters up to date. In that case, Mary Louisa and Teresa can be seen as just one link in a much larger information network that relied on letters as the principal tool of communication. And while there is little surviving evidence for other inter-convent correspondence, this letter cements the idea that biological bonds, despite the monastic intention of separation and death to the world, remained desirable but could only be maintained through correspondence.

\section{When the Ties That Bind Breakdown: The Next Generation of Carylls}

While the letters of Winefrid Thimelby, Mary Caryll, and the Hagan sisters show that outside connections were maintained despite enclosure and vows to be 'dead to the world', these relationships were not always easy to maintain. Distance, in this case both geographical and genealogical, could make relationships less dependable or valuable. When looking at familial letters more generally, we need to keep in mind that many relatives had either not been in physical contact in years or even decades, or had never met in person. Therefore, the act of writing, including the choice of words and the tone of each letter, was extremely important in determining whether a relationship continued to be beneficial or detrimental to the community. As Claire Walker has shown, "nuns inevitably employed writing styles commensurate with the task at hand." ${ }^{" 307}$ While nuns

\footnotetext{
${ }^{305}$ For more on spiritual sisterhood and convents as an extensions/replacement of the natal family see Lux-Sterritt, English Benedictine Nuns in Exile in the Seventeenth Century, 47-76.

${ }^{306}$ Mary Louisa Clare to her sister in Paris, March 26 1791, in English Convents in Exile, 6:282.

${ }^{307}$ Walker, "'Doe not supose me a well mortifyed Nun dead to the world'," 167.
} 
often utilized flattery and humility, they were also "not averse to using sarcasm and threats when necessary." ${ }^{\prime 308}$

Although Mary Caryll and her brother John Caryll passed away in 1712 and 1711 respectively, successive generations of the Caryll family continued to be heavily involved in convent networks, either as nuns or patrons. After his death, John Caryll's Jacobite title was passed along to his nephew, John Caryll the younger - who upon his death in 1736 was succeeded by his grandson John Baptist Caryll. ${ }^{309}$ While these successive members of the family continued their patronage of the Dunkirk Benedictine convent, it is apparent from the letters that their relationships with female relatives and kinswomen became more difficult to maintain. The main letter writers here include Arabella Benedicta Caryll - who was the daughter of John Caryll the younger and Aunt of John Baptist Caryll - as well as Abbesses Mary Frances Fermor and Benedicta Fleetwood. ${ }^{310}$ Although Fermor and Fleetwood had no blood relationship to the Carylls, their letters speak to the larger communication and patronage networks at play during this period.

In the letters of this next generation of Carylls, we can follow the deterioration of the relationships as familial ties become farther removed and strained by financial difficulty. In fact, as Claire Walker has stated, "throughout the eighteenth century, John Caryll's heirs were bombarded relentlessly by those he had endowed for the religious life, whose portions were in arrears." ${ }^{311}$ In one letter from Abbess Benedicta Fleetwood in

\footnotetext{
${ }^{308}$ Walker, "'Doe not supose me a well mortifyed Nun dead to the world'," 167.

${ }^{309}$ John Baptist Caryll would also go on to be Secretary of State to Charles III from 1769 to 1777. Howard Erskine-Hill, "Caryll, John, Jacobite second Baron Caryll of Durford," Oxford Dictionary of National Biography. 23 Sep. 2004. https://doi.org/10.1093/ref:odnb/4848

${ }^{310}$ See the entries for Mary Fermor (DB058), Anne Fleetwood (DB061), Arabella Caryll (DB026) in WWTN < https://wwtn.history.qmul.ac.uk> [accessed Dec 2 2019].

${ }^{311}$ Walker, "'Doe not supose me a well mortifyed Nun dead to the world'," 166.
} 
1730 to John Caryll, the younger, she appears surprised at his refusal "to pay what's so justly due to our house," and even quoted his words from a letter to his daughter back to him to strengthen her argument. ${ }^{312}$ Fleetwood notably ends her letter by writing, "I hope Sr $\mathrm{y}^{\mathrm{u}}$ will not take in ill part what I have sade for I should be very loath to disoblige a person I have allways lookd upon as a true friend." 313 This letter shows how carefully women religious constructed letters.

Letter writing required a delicate balance of being direct and confrontational while also being humble and flattering, in order to get what they, the nuns, required as well as keep their correspondent content. As we have seen, the practicalities of convent management meant that women religious were responsible for their own economic security. Therefore, on the advice of Abbess Benedicta Fleetwood, Arabella Benedicta Caryll steadily petitioned her male relatives to pay their debts to the Dunkirk convent. However, what is more interesting is that, in her letters, she "did not mince her words when she felt family honour was at stake." 314 When we look at the progression of Arabella Benedicta's letters, we can see how her tone and content evolves as her relationship with John Baptist fluctuates.

Arabella Benedicta's initial letters reiterate the themes of longing and humility present in Mary Caryll and Winefrid Thimelby's letters, while also expressing clear demands. In what appears to be her first letter to John Baptist in 1734, Arabella Benedicta writes, "I can no longer delay conversing with one so near and dear to me, since I've been frustrated of what I've so many years longd for; the comfort of your

\footnotetext{
312 British Library, Family of Caryll Correspondence, Vol. II. 1719-1731, Additional MS 28228 , fol. 409.

${ }^{313}$ BL Add. MS 28 228, fol. 409.

${ }^{314}$ Walker, "'Doe not supose me a well mortifyed Nun dead to the world"," 167.
} 
acquaintance." ${ }^{315}$ Although she begins the letter by reiterating her affection toward him and conversing about family news, specifically the breakdown of one of his marriage prospects, she quickly turns to her true reason for writing. Her real motivation is her desire to see him continue the original John Caryll's patronage and charity of her convent. ${ }^{316}$ To achieve her objective, she uses flattery and sympathy to try and elicit his support. She calls upon his "vertue \& goodness" to assist his "poor distrestd Aunts" with his patronage. ${ }^{317}$ Again, we see the strategic use of humility and even sympathy in order to attempt to secure support. ${ }^{318}$

When simply outlining the convent's precarious financial situation and appealing to his sense of empathy did not convince John Baptist to intervene, Arabella Benedicta took a more direct approach, this time employing a more rigid and frustrated tone. Similar to the earlier letter she relates some general news and reiterates her affection by writing, "I am ever mindfull of you at all times, and nothing can effaice you from my heart \& memory." ${ }^{19}$ But again, she quickly gets to her true purpose for writing, John Baptist's continual refusal to honour his debts and promises to the convent. ${ }^{320}$ At one point, she

${ }^{315}$ British Library, Family of Caryll Correspondence, Vol. III. 1732-1739, Additional MS 28 229, fol. 119.

${ }^{316}$ For example she writes, "small pention of 5 pon $[d]$ a year that my Father during his life allow'd us, \& that you orderd Mr Strickland before Christmass to return it, $\mathrm{w}^{\text {ch }}$ he had not yet don; to our great disapointment not having had one farthing since my fathers death, only a token from my poor Sister Catherin and he dying without leaving us any pention, or even a legacie makes our casse very hard," BL Add. MS 28 229, fol. 119.

${ }^{317}$ BL Add. MS 28 229, fol. 119.

${ }^{318}$ In this letter she also pleads with John by writing, "we being destitute of forces me to put our humble petition to you," BL Add. MS 28 229, fol. 119.

${ }^{319}$ British Library, Family of Caryll Correspondence, Vol. V. 1748-1755, Additional MS 28231 , fol. 26.

${ }^{320}$ She writes, "You know how willingly I have hetherto sufferd for your sake $\mathrm{y}^{\mathrm{e}}$ want of our yearly 5 pound constantly paid by my father, and my beging it now you may believe the utmost necessity compels me to it," BL Add. MS 28 231, fol. 26. As well as, "pay our Debts $\mathrm{w}^{\text {ch }}$ are to allmost all $\mathrm{y}^{\mathrm{e}}$ trades \& shops in Town, besides having tier'd out some friends by borowing to keep up our credit," BL Add. MS 28 231, fol. 48. 
attempts to persuade him by claiming that "justice is a Christian virtue, \& must be practis'd by all that hopes for eternall life," thus implying that his soul and afterlife were at risk should he not follow through on his promises. ${ }^{321}$ She also appeals to their ancestor's long history as respected patrons when she writes, "this house was begun by our Name [it is] a hard stroke to me to live to see you help to bring it down." ${ }^{322}$ In another letter, we can even discern a hint of sarcasm in her tone. At one point, while stating that she had not received any of the letters he claimed to have sent her, she muses that "tho $\mathrm{y}^{\mathrm{e}}$ post was then hazardous yet as none faild but yours" - a statement that suggests she is not convinced by his story. ${ }^{323}$

The letters of Arabella Benedicta Caryll also highlight the limitations of letter writing for women religious. While Arabella Benedicta employs a variety of techniques to try and convince John Baptist, it does not appear that her efforts paid off quickly. In 1751, for example, the new Abbess Mary Frances Fermor intervenes and chastises John Baptist for his "unkind silence" and "uncertain way of acting in $\mathrm{y}^{\mathrm{r}}$ accounts." 324 Fermor echoes some of Arabella Benedicta's sentiments and writes that John Baptist's actions are “injurious... [to his] Honour \& credit" as well as a discredit to his Ancestors. ${ }^{325}$ While it appears John Baptist did eventually agree to pay his debts, after numerous letters, it is clear that letter writing was not without limitations. The fact that these relationships had to be steadily maintained shows that women religious could never be truly separated from the concerns of the outside world.

\footnotetext{
${ }^{321}$ Quoted in Walker, "'Doe not supose me a well mortifyed Nun dead to the world'," 167; original found in BL Add. MS 28 230, fol. 97.

322 BL Add. MS 28 230, fol. 454.

${ }^{323}$ BL Add. MS 28 231, fol. 26.

${ }^{324}$ BL Add. MS 28 231, fol. 100.

${ }^{325}$ BL Add. MS 28 231, fol. 100.
} 
Comparison of the correspondence of Winefrid Thimelby and Mary Caryll reveals how women religious utilized familial letter writing for multiple purposes. Thimelby’s letters are filled with emotion and express anxiety for the spiritual wellbeing of her family, with little evidence of concern for politics or the larger world. On the other hand, Caryll's affection for her brother is less overt, but still present, and her letters are focused more on economic survival and political events. While their content and purpose might differ, the letters of both women clearly show how connected to, and invested they were, in their natal families. The correspondence of Arabella Benedicta Caryll complicates our understanding of early modern family dynamics even further. In her letters, Arabella Benedicta does not appear to have the same emotional connection to her correspondent as Winefrid and Mary, but she still attempts to utilize familial affection and history to her advantage. Finally, the correspondence of the Hagan sisters demonstrates that letters facilitated both transnational links, in this case between France and America, but also inter-conventual links between biological sisters in different convents. The correspondence of all these women highlight that, regardless of motivation, letters allowed nuns to remain connected to the outside world and the families they left behind despite the religious ideal of separation and isolation. 


\section{Chapter 2: Correspondence During Conflict}

During the seventeenth century two English Benedictine convents, one at Cambrai and the other at Brussels, experienced tumultuous disputes that resulted in extensive epistolary activity. At Cambrai, conflict arose in 1655 when the president of the Benedictine Congregation threatened to remove books written by the convent's late spiritual director, Augustine Baker. In Brussels, the convent was internally divided over spiritual direction, which led numerous nuns to reach out to the Archbishop of Mechelen as an external mediator. The correspondence produced during the Cambrai book dispute and Brussels controversies shows that women religious strategically utilized letters to navigate internal and external disputes. Although letters written during conflicts appear to have, on the surface, very explicit motivations, they cannot be taken at face value. The perspectives and hidden motivations of the letter writers must be critically examined since exaggeration, gossip, and rumour were intentional tools of nuns' correspondence. For instance, arguments raised around a scandalous priest, witchcraft, physical violence or abuses of power - all of which exist in the Brussels letters - cannot be accepted as historical fact without careful analysis. Letters do not "represent an uncomplicated narration of life events;" instead, they were carefully constructed to negotiate and control conflict. $^{326}$

Reading epistolary activity in this way allows us to shift our focus from letters as historical evidence, to letters as the subject; thereby, emphasizing the process, construction and women responsible for the product. ${ }^{327}$ It is evident that letters were a

\footnotetext{
${ }^{326}$ Leonie Hannan, Women of Letters: Gender, Writing and the Life of the Mind in Early Modern England (Manchester: Manchester University Press, 2016), 9.

${ }^{327}$ Gabriella Del Lungo Camiciotti, "Letters and Letter Writing in Early Modern Culture: An Introduction," Journal of Early Modern Studies 3, no. 3 (2014): 29.
} 
conduit for conflict, encouraging discontent rather than resolving it. Despite its importance, letter writing has largely been overlooked as the primary tool utilized by women religious to engage in convent disputes. While many historians have focused on the Cambrai nuns as writers and translators of manuscripts or books, letters have been omitted from discussions of their literary production. ${ }^{328}$ Examination of nuns' correspondence reveals both their commitment to controlling their religious lives and the powerful role letters played in this struggle. As Teresa Gage, a nun in Brussels, remarked, "I am constrained to take the bouldnes, once more to addresse my selfe unto $\mathrm{y}^{\mathrm{r}}$ most Ill ${ }^{\text {tus }}$ Lordp," - a boldness to write that she, and many others, would resort to in order to navigate conflict. ${ }^{329}$

\section{"We might not feed upon poisnous doctrine": The Cambrai Book Dispute}

In 1655 , a number of letters sent from the Benedictine nuns at Cambrai and Paris were intercepted and seized by John Thurloe, Secretary of State and head of intelligence services in England. ${ }^{330}$ The letters, sent via messenger, were intercepted as part of Oliver

\footnotetext{
${ }^{328}$ For a selection of historical scholarship on the Cambrai book dispute see: Victoria Blud, "Beyond the Sea: Medieval Mystic Space and Early Modern Convents in Exile," in Gender in Medieval Places, Spaces and Thresholds, ed. by V. Blund, D. Heath, and E. Klafter (London: University of London Press, 2019), 75-90; Caroline Bowden, "Building Libraries in Exile: The English Convents and Their Book Collections in the Seventeenth Century," British Catholic History 32, no. 3 (2015): 383-389; Jaime Goodrich, Faithful Translators: Authorship, Gender and Religion in Early Modern England (Evanston, Illinois: Northwestern University Press, 2013); Claire Walker, "Spiritual Property: The English Benedictine Nuns of Cambrai and the Dispute over the Baker Manuscripts," in Women, Property and the Letters of the Law in Early Modern England, ed. by N.E. Wright, M.W. Ferguson, and A. R. Buck (Toronto: University of Toronto Press, 2004), 237-255.

${ }^{329}$ The Brussels letters have been preserved in the Archief van het Aartsbisdom Mechelen (hereafter AAM) in Belgium as Engelse Benedictinessen Doos 12/1-12/3, all letters unfoliated. The majority of these letters were written by the nuns to Archbishop Jacobus Boonen. Teresa Gage to Jacobus Boonen, June 23 1638, AAM, Engelse Benedictinessen, 12/3.

330 The Cambrai Benedictine house was founded in 1623 by Helen More (better known in religion as Gertrude) and eight other English women. Walker, "Spiritual Property," 240; Blud, "Beyond the Sea," 77.
} 
Cromwell's efforts to "discover Royalist plots and monitor foreign affairs" and were only discovered in 1742 in a false ceiling in Thurloe's home. ${ }^{331}$ The letters were considered unremarkable at the time, devoid of Royalist scheming. Today they provide valuable insight into the spiritual direction of women religious and the controversy that ensued when they asserted their independence and challenged external authority. On March $3^{\text {rd }}$ and $4^{\text {th }} 1655$, Catherine Gascoigne, abbess at the time, and Christina Brent took up their pens to contact multiple priests as well as family members. Their letters not only highlight the importance of convent patronage networks, but also reiterate the power that letters provided women religious as a means to solicit support. ${ }^{332}$

From the outset, the Cambrai house set itself apart from other English convents through its spirituality. Given that they were part of a contemplative rather than active order, the women of Cambrai, and all other English nuns, "were expected to achieve a fulfilling spiritual relationship with the divine" based on personal meditation and prayer. ${ }^{333}$ Many English convents on the continent followed the spiritual practices of the Society of Jesus, and the Spiritual Exercises of Ignatius Loyola. ${ }^{334}$ Although Jesuits were restricted from becoming confessors in convents, they maintained considerable

\footnotetext{
${ }^{331}$ Victoria Van Hyning, "Convent Controversy and Intercepted Letters from Cambrai and Paris: 'We are now brought into most narrow straites'," in English Convents in Exile, 1600-1800: Volume 3. Life Writing I, ed. by Nicky Hallett, Elizabeth Perry and Victoria Van Hyning (London: Pickering \& Chatto, 2012), 285.

${ }^{332}$ Van Hyning, "Convent Controversy and Intercepted Letters from Cambrai and Paris," 286.

${ }^{333}$ Walker, "Spiritual Property," 238.

${ }^{334}$ As Victoria Blud has neatly summarized, the Spiritual Exercises "were regularly used in the convents and were adapted for a number of different audiences. They comprise exercises and meditations moving through purgative, illuminative and perfective stages... The method focuses on the dialogue between director and exercitant, with a view to equipping directors with the necessary tools to guide their charges," "Beyond the Sea," 77; Claire Walker, Gender and Politics in Early Modern Europe: English Convents in France and the Low Countries (New York: Palgrave Macmillan, 2003), 131, 135.
} 
influence. ${ }^{335}$ In fact, three nuns "schooled in Jesuit spirituality" were sent from Brussels to spread this approach to the newly founded Cambrai convent. ${ }^{336}$ Their spirituality evidently failed to satisfy the women of Cambrai, who quickly petitioned the English Benedictine congregation to send them a director practising Benedictine contemplative prayer. ${ }^{337}$ The request resulted in the arrival of Augustine Baker.

Augustine Baker arrived at the Cambrai convent in 1624 and quickly set himself apart from other spiritual advisors of his time. ${ }^{338}$ Baker was critical of Jesuit teaching as well as "interventionist confessors" who, he argued, neglected to "advise according to the character of each soul" and instead "simply trained inexperienced nuns in their own prayer techniques." 339 Baker's spiritual method rejected "the discourse, set meditations, and close supervision that characterised Ignatian piety," and alternatively promoted "a spirituality in which the soul was led by God alone." 340 By allowing the Cambrai nuns more control over their spiritual direction, Baker (deliberately or not) encouraged within them a level of independent thinking not promoted in other convents. ${ }^{341}$ Further, Baker was unique for his time since he was "advocating...[liberation] at a time when the

\footnotetext{
${ }^{335}$ Jesuit influence was largely carried out through their role as spiritual directors and the dissemination of devotional texts. Bowden, "Building Libraries in Exile," 365.

${ }^{336}$ Walker, Gender and Politics in Early Modern Europe, 143. For more on the Jesuit's role in English convents see James E. Kelly, "Jesuit News Networks and Catholic Identity: The Letters of John Thorpe to the English Carmelite Nuns at Lierre, 1769-89," in Jesuit Intellectual and Physical Exchange Between England and Mainland Europe, c.1580-1789, ed. by J. E. Kelly and H. Thomas (Leiden: Brill, 2018) 337-360; Walker, Gender and Politics in Early Modern Europe, 134-142.

${ }^{337}$ Walker, "Spiritual Property," 240; Liam P. Temple, "The Mysticism of Augustine Baker, OSB: A Reconsideration," Reformation \& Renaissance Review 19, no. 3 (2017): 216.

${ }^{338}$ Walker, "Spiritual Property," 238; Bowden, "Building Libraries in Exile," 365.

${ }^{339}$ Walker, Gender and Politics in Early Modern Europe, 144. For more on Baker's teachings see: Temple, "The Mysticism of Augustine Baker," 213-230.

${ }^{340}$ Walker, Gender and Politics in Early Modern Europe, 144.

${ }^{341}$ Van Hyning, "Convent Controversy and Intercepted Letters from Cambrai and Paris," 285.
} 
Catholic Church recommended greater clerical regulation of spirituality, particularly for women." 342

Largely based on the desires and requests of the nuns, Baker wrote books and prayer manuals to support the convent's devotional practices. ${ }^{343}$ But beyond Baker's own works, the Cambrai nuns took an active role in the process, both influencing and distributing Baker's spiritual writings. The nuns copied, collected and edited Baker's manuscripts. This resulted in new versions, which they sent to their daughter house in Paris and to the Carmelites in Antwerp. ${ }^{344}$ The literary production of the Cambrai nuns served an almost missionary purpose, supplying books and spirituality to family members, fellow women religious, and recusant Catholics more broadly. ${ }^{345}$ Multiple nuns, including Gertrude More, Catherine Gascoigne and Barbara Constable, went on to write their own spiritual works that earned them respect and recognition. ${ }^{346}$ For example, Gertrude More wrote a defence of Baker and his methods, entitled Apology for Herself and Her Spiritual Guide, as well as an explanation of Cambrai spirituality entitled, The Spiritual Exercises (published in 1658). ${ }^{347}$ As Caroline Bowden has noted, the latter work

\footnotetext{
${ }^{342}$ Walker, "Spiritual Property," 240. Jaime Goodrich has commented on Baker's approach that he, "did not take a prescriptive stance, instead urging the nuns to determine which texts met their particular needs: 'Observe your own way... and of books, take and practise according as you shall find to be proper and answerable to such a way, spirit, and call of yours," Faithful Translators: Authorship, Gender and Religion in Early Modern England, 167.

${ }^{343}$ Walker, "Spiritual Property," 240; Heather Wolfe, "Dame Barbara Constable: Catholic Antiquarian, Advisor, and Closet Missionary," in Catholic Culture in Early Modern England, ed. by R. Corthell, F. E. Dolan, and A. F. Marotti (Notre Dame: University of Notre Dame Press, 2008), 163.

${ }^{344}$ Bowden, "Building Libraries in Exile," 366; Walker, Gender and Politics in Early Modern Europe, 145.

${ }^{345}$ Wolfe, "Dame Barbara Constable," 170.

${ }^{346}$ Blud, "Beyond the Sea," 76.

${ }^{347}$ Blud, "Beyond the Sea," 86-87; Walker, Gender and Politics in Early Modern Europe, 145. For more on Gertrude More (CB137) see her entry in WWTN <https://wwtn.history.qmul.ac.uk> [accessed June 23 2020]. Remarkably, at the end of her life More had such faith in Baker's
} 
was "among the most widely found single texts in the libraries of the English

convents." 348 Barbara Constable was also a prolific transcriber, translator and writer, who created multiple spiritual guides and advice books. ${ }^{349}$ As Jenna Lay has argued, although Constable claimed that her works were "straightforward collections out of other authors...her quotations of religious authorities are often reduced to brief extracts framed by her own extensive commentary." 350 This shows that the Cambrai nuns asserted their own expertise in textual matters in a way that far exceeded Baker's initial influence. The nuns were not passive recipients of Baker's teachings, but rather actively involved in crafting "an alternative spirituality." 351 When looking at the letters written during the Cambrai dispute, we can see that nuns' textual expertise went beyond manuscript production to encompass their letter writing activity.

Under Baker, the Cambrai nuns "acquired a reputation for intense piety," which was extremely valuable given the importance of reputation in acquiring charity and new recruits. ${ }^{352}$ Catherine Gascoigne testified to the independent spirit of the Cambrai nuns when she claimed "she and her sisters were 'sufficiently entered and founded in their

\footnotetext{
methods, and her own spiritual knowledge, that she said, "she could confidently go out of this life without speaking to any man," Blud, "Beyond the Sea," 87; Walker, "Spiritual Property," 241. ${ }^{348}$ Bowden, "Building Libraries in Exile," 366.

${ }^{349}$ The most famous of which included, Advises: For Confessors and Spirituall Directors, Speculum Superiorum, and Considerations for Preests. See Jenna Lay, "An English Nun's Authority: Early Modern Spiritual Controversy and the Manuscripts of Barbara Constable," in Gender, Catholicism and Spirituality: Women and the Roman Catholic Church in Britain and Europe, 1200-1900, ed. by Laurence Lux-Sterrit and Carmen M. Mangion (Basingstoke: Palgrave Macmillan, 2011), 100. For more on Barbara Constable (CB043) see her entry in WWTN <https://wwtn.history.qmul.ac.uk> [accessed June 23 2020]; as well as Genelle Gertz, "Barbara Constable's Advice for Confessors and the Tradition of Medieval Holy Women," in The English Convents in Exile, 1600-1800, ed. by Caroline Bowden and James E. Kelly (Burlington, VT: Ashgate, 2013), 123-138; Wolfe, "Dame Barbara Constable," 158-188.

${ }^{350}$ Lay, “An English Nun's Authority,” 100.

${ }^{351}$ Walker, "Spiritual Property," 240.

${ }^{352}$ Walker, "Spiritual Property," 241.
} 
spirituall course...to undertake the office of teaching the younger [nuns]'."353 This declaration, that women religious could have not only the ability but the knowledge necessary to dictate their own spiritual direction, undoubtedly would have troubled many ecclesiastical authorities. When we consider the correspondence of the Cambrai nuns, we can see that the unique level of independence fostered by Baker played a vital role in shaping their correspondence.

Baker's spiritual direction apparently satisfied the Cambrai convent until the arrival of Francis Hull in 1629 to serve as their official confessor. ${ }^{354}$ Hull quickly became troubled by Baker's influence. In an effort to maintain his authority as confessor, Hull encouraged the nuns to abandon Baker's instructions and follow a Jesuit method of prayer. ${ }^{355}$ Hull's recommendations were largely unsuccessful, and the house continued to follow and promote Baker's teachings. In 1633, questions were raised again by Hull regarding "the orthodoxy of Baker's teachings." ${ }^{356}$ His books were examined by the English Benedictine Congregation but were eventually cleared of "any heretical tendencies." ${ }^{357}$ While Baker's books and teachings were exonerated, both Baker and Hull were removed from the house in an attempt to avoid further conflict. ${ }^{358}$ Baker died in

\footnotetext{
${ }^{353}$ Walker, Gender and Politics in Early Modern Europe, 145. For more on Catherine Gascoigne (CB074) see her entry in WWTN < https://wwtn.history.qmul.ac.uk> [accessed Feb 25 2020].

${ }^{354}$ It is important to note here the difference between confessor and spiritual director: Hull as confessor, would hear confession, and Baker, as spiritual director, was responsible for "devotional method and spiritual discernment," Gertz "Barbara Constable's Advice for Confessors and the Tradition of Medieval Holy Women," 123.

${ }^{355}$ Goodrich, Faithful Translators, 172.

${ }^{356}$ Bowden, "Building Libraries in Exile," 366.

${ }^{357}$ Bowden, "Building Libraries in Exile," 366; Goodrich, Faithful Translators, 172. It is important to note that, "unlike the majority of English cloisters, Cambrai was affiliated with the English Benedictine congregation, which meant that the nuns were subject to its superior (termed the president) rather than to the local bishop," Walker, "Spiritual Property," 240.

${ }^{358}$ Goodrich, Faithful Translators, 172.
} 
London in $1641 .{ }^{359}$ Nonetheless, these early debates over Baker's teachings are particularly interesting when compared to the events of 1655 . In the latter conflict, concern over Baker's books had less to do with the alleged heretical nature of the books themselves, and more with how they "subverted ecclesiastical authority by encouraging the nuns to assert their independence in matters beyond the purely spiritual realm." ${ }^{\prime 60}$ The independence the nuns had acquired under Baker's spiritual direction is what became most threatening. This same independence is what emboldened them to take up their pens and challenge the demands of ecclesiastical authorities.

In 1655, Cambrai became embroiled in yet another dispute when Claude White, President of the English Benedictine congregation, attempted to confiscate Baker's books. ${ }^{361}$ White allegedly justified his actions by arguing that they contained, "poysonous, pernicious \& diabolicall doctrine." ${ }^{362} \mathrm{He}$ ordered the convent to "relinquish the original Baker treaties" so that he could "expunge them of all erroneous teaching."363 White's plan to expurgate Baker's writings greatly distressed Catherine Gascoigne. She wrote that it would be "an injury to all such of the congregation that do esteeme them that I cannot in conscience give my consent to put them into his hands. ${ }^{364}$ These are the words of a woman refusing to bend to external authority, and using epistolary space to assert her perspective. The use of the word 'consent' strategically affirms Gascoigne's

\footnotetext{
${ }^{359}$ Walker, "Spiritual Property," 241.

${ }^{360}$ Walker, "Spiritual Property," 242.

${ }^{361}$ Claude White had been present at the 1633 examination and had voted in Baker's favour, but it is unclear what caused White to change his position on the books between 1633 and 1655, Van Hyning, "Convent Controversy and Intercepted Letters from Cambrai and Paris," 285.

${ }^{362}$ Catherine Gascoigne relays White's justification in her letter to Mr. Conyers, Bodlelian Library, Oxford, Thurloe's Papers Vol. XXXVI, March 1656, Rawlinson MS A.36, fol. 45.

${ }^{363}$ Walker, "Spiritual Property," 242.

${ }^{364}$ Bodl. Rawlinson MS A.36, fol. 49.
} 
role as an authority figure within the convent while also subverting the expectation of the submissive, obedient, nun.

In response to the nuns' desire to maintain control of the books, White visited the convent in March. According to Gascoigne, he made a number of "terrifieng speeches," and interrupted the women when they attempted to defend their stance. ${ }^{365}$ Each woman was then pressed by White, before the entire congregation, to declare her desire to continue the petition or not - knowing full well the answer Father Claude White wanted to hear. Gascoigne wrote of the proceedings, "he called my selfe and $\mathrm{y}^{\mathrm{e}}$ whole convent by one and one shewing each a paper...in was written these words. do you persist in the desire of the petition I or no is a sufficient answere ...by all circumstances the greater part of the company persisted in the desire of the petition." ${ }^{366}$ The persistence of the Cambrai nuns to stand their ground, in the face of external authority, highlights the idea that they took an active role in spearheading and preserving their spiritual direction. However, when it became clear that White was not going to be successful through appeals and intimidation, he resorted to blackmail. He refused to approve the profession of three novices, a move that directly threatened the convent's income. ${ }^{367}$ This move had a significant impact on the nuns. Writing a few days after White's visit, Christina Brent remarked that she wished to put "'the affaire of the bookes [to] rest', so that the strain and practical problems it had brought...might be concluded." 368 It is important to note that

\footnotetext{
${ }^{365}$ Bodl. Rawlinson MS A.36, fol. 49.

${ }^{366}$ Bodl. Rawlinson MS A.36, fol. 49.

${ }^{367}$ The dowries would have brought around $£ 1,000$ into the convent, Walker, "Spiritual Property," 252. Before the women could be professed White was meant to meet with each of the novices, but according to Catherine Gascoigne, "he would not see or speak $\mathrm{w}^{\text {th }}$ them, before he had satifacti[on] in what he desired," Bodl. Rawlinson MS A.36, fol. 49.

${ }^{368}$ Blud, "Beyond the Sea," 86; Bodl. Rawlinson MS A.36, fol. 53.
} 
even though Brent desired the conflict to end, she did not concede to White but rather continued an active defence through her letters.

While the letters of the Cambrai nuns are significant for the evidence they provide of the details of the 1655 dispute, they also reveal how this medium was utilized as a tool of power for women religious. From Gascoigne's letters, Claude White did not appreciate being challenged. She wrote that during his visit he declared, "to persist in [their petition] was absolut disobedience." 369 For White, the nuns' persistence challenged not only his authority but the traditional expectation of nuns as meek and subservient. In order to continue to assert their views, Christina Brent and Catherine Gascoigne turned to the only communication method at their disposal, letters. One letter, written by Gascoigne to a "Mr Robinson," emphasized the convent's situation when she remarked, "the great straights wee are brought to in our affaires by the resolute persisting of Mr Whit in his demands hath inforced us in so particular a manner to have recourse to our frends." 370 While this passage highlights the necessity of reaching out to allies, it also effectively utilized empathy and concern as a means of persuasion. As Claire Walker has argued, in the context of a convent's economic interests, letter writing required negotiating a "fine line between defence of...[a] convent's interests and alienation of potential allies...if they wrote too stridently, they might risk any chance of securing the matter at hand." 371 This same logic can be extended to times of conflict, as the Cambrai nuns had to be strategic in the information and tone they conveyed to their allies. For example, in one letter, Gascoigne remarked that this conflict was leading the convent "in a damnable way

\footnotetext{
${ }^{369}$ Bodl. Rawlinson MS A.36, fol. 49.

${ }^{370}$ Bodl. Rawlinson MS A.36, fol. 57.

${ }^{371}$ Walker, "'Doe not supose me a well mortifyed Nun dead to the world'," 164.
} 
running to perdition" - or rather a state of eternal damnation, a claim that, for devout Catholics, would not have been taken lightly. ${ }^{372}$

Beyond consistently reiterating the peril of their situation, Gascoigne and Brent also utilized past experiences as a tool in their epistolary repertoire. For instance, Brent wrote to "Mr Vanderhaghen" - an alias for Father Anselm Crowder, her agent in England - that he had always treated them with "care, charity, \& affection" which made them “confident of...[his] assistance at this present." ${ }^{373}$ Brent's words work to cleverly reinforce the relationship between Cambrai and Crowder, while also stressing that they expected his support. In one of her letters to Crowder, Gascoigne referenced the past controversy with the books and noted that they were approved by fathers "both learned and pious." ${ }^{374}$ With this phrase, Gascoigne utilizes gender norms of male expertise to lend the books more authority, and paints the conflict as much larger than simply the nuns against White. ${ }^{375}$ In the same letter, Gascoigne framed the dispute in terms of its larger consequences for other Benedictine monasteries, moving the scale beyond the confines of the Cambrai convent. She wrote:

"I humbly beseech you therfore to looke upon this affaire, not as a thinge only concernning our house, but the whole congre: $\mathrm{w}^{\text {ch }}$ indeed is interested in it both in respect of the bookes and the proceedings of our vRd Fa: presi: against us, upon such grounds, $\mathrm{w}^{\mathrm{ch}}$ may be the case, of any other houses of the congrega: upon every diference betwixt the presi: ${ }^{t}$ and the superior of it to the prejudice of their spirituall and temporall good and the unmeasurable disturbance of their peace so much desired and regarded by all.",376

\footnotetext{
${ }^{372}$ Bodl. Rawlinson MS A.36, fol. 45.

${ }^{373}$ Bodl. Rawlinson MS A.36, fol. 53; Walker, "Spiritual Property," 249.

${ }^{374}$ Bodl. Rawlinson MS A.36, fol. 49.

${ }^{375}$ Walker, "Spiritual Property," 249.

${ }^{376}$ Bodl. Rawlinson MS A.36, fol. 49.
} 
Gascoigne adds pressure to Vanderhaghen to not let this dispute become a precedent for further disagreements.

In addition to reaching out to ecclesiastical authorities, Christina Brent wrote to her brother, William Brent, asking him to assist their messenger during his stay in London. Brent acknowledged that "although I seldom write to you...you are often rememberd in the prayers... of your affectionate sister." 377 This suggests that family connections, even if not continually sustained, were an important resource for women religious during conflict. Moreover, these letters represent only a few days' worth of correspondence. We can assume that many more letters were sent, employing similar appeals, strategies, and defences. In fact, two letters from Father Conyers and Father Crowder to Catherine Gascoigne have been preserved. They demonstrate that correspondence on the book controversy began much earlier than March $1655 .{ }^{378}$ This small selection of correspondence shows us that, in order to maintain control of their spiritual direction, the Cambrai nuns had to tactically utilize letter writing. Without letters, Gascoigne and Brent would have had little recourse or ability to effectively challenge White's authority.

In the end, the Cambrai convent resisted White's attempts to remove Baker's books, and his death shortly thereafter suppressed any further opposition towards them. ${ }^{379}$ However, the controversy did have consequences for the convent. Records show that only one nun, Gascoigne's niece Frances, was professed in the convent between 1656 and

\footnotetext{
${ }^{377}$ Bodl. Rawlinson MS A.36, fol. 63.

${ }^{378}$ The letter from Conyers is dated to January 19, 1654, and Crowder from January 26, 1655; Bodl. Rawlinson MS A.36, fols 85, 89.

${ }^{379}$ Walker, "Spiritual Property," 242.
} 
1662. ${ }^{380}$ This highlights the fact that even though the Cambrai nuns technically 'won' by retaining control of Baker's books, the doubts that were raised remained long after the conflict. In this case, letter writing was a powerful tool for the nuns to reach out to allies and to secure support. But it also allowed the conflict to reach a much wider audience than if it had been confined to the convent walls. Therefore, while letters were an essential tool for women religious, they had to be strategically constructed in order to both achieve their objectives and mitigate risk.

\section{"Excesseve and intollerable disquiat": The Brussels Benedictine Dispute}

"out of the extremtye of my Greef and afflicted hart, I make bould to present this my humble petition unto your Lordshipe, beseechinge you for sweet Jesus sake to commiserat my case and assist me in this my distresse" - Margerie Cotton. ${ }^{381}$

Although recognized as the first English convent founded on the continent, the Brussels Benedictine house is perhaps more prominent in historical scholarship for the numerous conflicts that took place within its walls. ${ }^{382}$ These disputes spanned multiple decades and covered a range of issues, but ultimately resulted in an abundance of letters. Over the course of the Brussels conflicts, letters were written by numerous women religious, including the prolific Abbess Mary Percy, to the Archbishop of Mechelen,

\footnotetext{
${ }^{380}$ Walker, Gender and Politics in Early Modern Europe, 25. Walker has also shown that this was distinct from other convent recruitment patterns of the time, concluding that this controversy negatively set Cambrai apart.

${ }^{381}$ Margerie Cotton to Jacobus Boonen, April 27 [1624], AAM, Engelse Benedictinessen, 12/1.

${ }^{382}$ For a selection of scholarly sources on the Brussels convent disputes see: Walker, Gender and Politics in Early Modern Europe, 138-142; Jaime Goodrich, "Authority, Gender, and Monastic Piety: Controversies at the English Benedictine Convent in Brussels, 1620-1623," British Catholic History 33 (2016): 91-114; Emilie K.M. Murphy, "Language and Power in an English Convent in Exile, c.1621-c.1631," The Historical Journal (2018): 1-25; Bronagh Ann McShane, "Visualising the Reception and Circulation of Early Modern Nuns' Letters," Journal of Historical Network Research 2 (2018): 1-25.
} 
Jacobus Boonen, the convent's governing ecclesiastical authority. ${ }^{383}$ The first conflict at Brussels, beginning in 1620 and lasting until 1623, began as a rift between Abbess Mary Percy and the convent's ordinary confessor Robert Chambers, but evolved with the arrival of a new (and young) confessor Francis Ward. ${ }^{384}$ With the presence of Ward came spiritual factionalism, allegations of abuse of authority, and rumours of indecency. This conflict was only resolved after a number of nuns, particularly those sympathetic to the Jesuits, accused Ward in their letters of "attempting to seduce an impressionable young nun" and he was removed from the house. ${ }^{385}$ Although Chambers also left the house (sometime in 1623), the tension was further eased after a number of "dissident" nuns left to establish two new convents, one at Cambrai in 1623 and the other at Ghent in $1624 .{ }^{386}$

The second disagreement repeated similar concerns over spiritual direction after Archbishop Boonen appointed a new confessor, Anthony Champney, in 1628 who was anti-Jesuit. ${ }^{387}$ Although one third of the convent opposed Champney, he was not removed as confessor and the conflict was only resolved when the pro-Jesuit nuns left Brussels,

\footnotetext{
${ }^{383}$ Upon its foundation Brussels was placed under the authority of the archbishop of MechelenBrussels since the English Benedictine Congregation had not yet been established, Goodrich, "Authority, Gender, and Monastic Piety," 95. For more on monastic governance and its role in mediating convent disputes see Walker, Gender and Politics in Early Modern Europe, 66-73. As Walker has argued, external authorities, such as the Archbishop of Mechelen, could be "a positive element of internal monastic government...should an abbess prove incompetent or tyrannical...these mediators could resolve the problem," Gender and Politics in Early Modern Europe, 70.

${ }^{384}$ Goodrich, "Authority, Gender, and Monastic Piety," 92. Robert Chambers became the house's ordinary confessor in 1599. Mary Percy professed in 1600 and was abbess from 1616 to 1642 , see her entry (BB135) in WWTN < https://wwtn.history.qmul.ac.uk> [accessed Mar 24 2020].

${ }^{385}$ Goodrich, "Authority, Gender, and Monastic Piety," 92.

386 The Ghent house quickly developed a close relationship with the Jesuits due to the fact that three of the women who founded it (Lucy Knatchbull, Eugenia Poulton, Magdalen Digby) were pro-Jesuit in the Brussels dispute. The women who left for the Cambrai house included Potentiana Deacon, Frances Gawen, and Viviana Yaxley. Goodrich, "Authority, Gender, and Monastic Piety," 91, 110-111; Murphy, "Language and Power in an English Convent in Exile," 9.

${ }^{387}$ Walker, Gender and Politics in Early Modern Europe, 71.
} 
followed soon after by Champney's own departure in $1637 .{ }^{388}$ Yet this controversy had serious consequences for the convent and greatly affected both their finances and recruitment. In fact, while 68 women professed at the Ghent convent, only three professed at Brussels between 1628 and $1651 .^{389}$ The continuous controversies at Brussels, advertised far and wide through letters, certainly played a significant role in the decline in recruitment. The final controversy occurred in the early 1650 s, when the Archbishop imposed Alexia Blanchard as abbess, to the dismay of the majority of the convent. ${ }^{390}$ This conflict again resulted in many letters but was short lived since Blanchard died in $1652 .{ }^{391}$

It is necessary to consider some of the strategic choices that these letter writers made before exploring the content and themes of the Brussels correspondence. As Emilie K. Murphy has stated, nearly all the Brussels letters, "were written using petitionary language of deference and supplication (the majority of the letters are signed...with 'your Lordships most obedient child')." ${ }^{992}$ The use of passive or deferential language is significant, since in this context it can be viewed as a deliberate choice. As James Daybell has argued, rather than being indicative of "women's feelings of inferiority to men" the use of submissive language and "images of female weakness and incapacity

\footnotetext{
${ }^{388}$ Walker, Gender and Politics in Early Modern Europe, 71.

${ }^{389}$ These controversies also affected the convent's income which in 1631 was 12,164 florins but by 1632 had dropped to 5,569, and did not recover until the 1650's. Jaime Goodrich, "Nuns and Community-Centered Writing: The Benedictine Rule and Brussels Statutes," Huntington Library Quarterly 77, no. 3 (2014): 299.

${ }^{390}$ Walker, Gender and Politics in Early Modern Europe, 71.

${ }^{391}$ Walker, Gender and Politics in Early Modern Europe, 72. For more on how this last conflict was resolved see Claire Walker, "Recusants, Daughters and Sisters in Christ: English Nuns and their Communities in the Seventeenth Century," in Women, Identities and Communities in Early Modern Europe, ed. by Stephanie Tarbin and Susan Broomhall (Aldershot: Ashgate, 2008), 74.

392 Murphy, "Language and Power in an English Convent in Exile," 6.
} 
were employed by women to their own advantage." 393 For example, after providing their perspectives, in separate letters, on the spiritual controversy at the convent, Potentiana Deacon and Lucy Knatchbull asked the Archbishop to pardon them - Deacon for her "playnes" and Knatchbull for her "bouldnes." 394 In another letter Mary Percy, clearly a confident and authoritative woman, lamented that the role of abbess was, "fitter for a stronger pson every way then I think my self to be." ${ }^{395}$ Nonetheless, she went on to carry the heavy burden regardless. ${ }^{396}$

Other examples demonstrate that there was a dichotomy between the passivity of tone used in the Brussels letters and the assertiveness of their contents. When Ursula Hewick appealed to Archbishop Boonen not to send her to the new Cambrai convent, she intentionally listed her multiple faults in order to ensure she did not leave Brussels. At one point in her letter, Hewick wrote that the Cambrai congregation would suffer, "by having so lame a member to so important a worke." ${ }^{397}$ By situating herself as "lame," Hewick walked a fine line between exposing her faults in a way that made her unsuitable

\footnotetext{
393 James Daybell, "Introduction," in Early Modern Women's Letter-Writing, 1450-1700, ed. by J. Daybell (Basingstoke: Palgrave Macmillan, 2001), 9. For more scholarship on the use of language in this way see Vivienne Larminie, "Fighting for Family in a Patronage Society: the Epistolary Armoury of Anne Newdigate (1574-1618)," in Early Modern Women's LetterWriting, 1450-1700, ed. by J. Daybell (Basingstoke: Palgrave Macmillan, 2001), 159-176; Alison Wall, "Deference and Defiance in Women's Letters of the Thynne Family: the Rhetoric of Relationships," in Early Modern Women's Letter-Writing, 1450-1700, ed. by J. Daybell (Basingstoke: Palgrave Macmillan, 2001), 77-93.

${ }^{394}$ Potentiana Deacon to Jacobus Boonen, August 26, AAM, Engelse Benedictinessen, 12/2. Lucy Knathcbull to Jacobus Boonen, AAM, Engelse Benedictinessen, 12/2.

${ }^{395}$ Mary Percy to Jacobus Boonen, AAM, Engelse Benedictinessen, 12/2.

${ }^{396}$ Mary Percy to Jacobus Boonen, AAM, Engelse Benedictinessen, 12/2.

${ }^{397}$ Ursula Hewick to Jacobus Boonen, October 23 1623, AAM, Engelse Benedictinessen, 12/1. Hewick also wrote, "the person sent for such imployments hath need to be of good sufficiencie aswell as in solid vertue, as in force of bodie \& spirit...to lay a foundation of Religion perfection; and for my part God knowes how much I am... wanting of such vertue in my soule, \& by my age which is 52 yeares (\& burthened with many infirmities) I am so weake in vodie \& spirit."
} 
for Cambrai, but still a valuable member in Brussels. ${ }^{398}$ Alexia Blanchard took a different, yet equally deliberate approach, when she pleaded with Boonen to send her to the Cambrai convent. Blanchard wrote:

"Give me your leave...for soe great is; and hath ben the affliction of my soule, to see our congregation soe much disordred, \& desunited; that I ame not able to indure it without eminent danger of hurting my soule... for sweet jesus sake have compassion on me, and release me of my extreame afflictions." 399

Blanchard's letter is designed to elicit sympathy and compassion from Boonen. Its construction was a conscious decision on Blanchard's part. These examples illustrate that women religious utilized diverse, and deliberate, epistolary techniques to achieve their goals during convent conflicts.

In terms of letter content, the correspondence of the Brussels nuns shows that they were deeply divided over spiritual direction, resulting in multiple factions within the house. All resorted to letter writing to advance their position. Abbess Percy's letters testify that the initial discontent in Brussels grew out of a disagreement between herself and Father Robert Chambers. ${ }^{400}$ Percy felt that Chambers "undermined her governance" while Chambers complained that Percy, "damage[d] his spiritual authority within the house...[with her] longstanding refusal to confess to him." ${ }^{401}$ Lucy Knatchbull wrote that Chambers could be "rough \& resolute in giving his opinion, $w^{\text {th }}$ out waighinge the disposition of the partie whome he dealeth" and Percy could be "sildome and hardly

\footnotetext{
${ }^{398}$ Hewick died in Brussels in 1638 meaning her request to not be moved was granted. See her entry (BB097) in WWTN < https://wwtn.history.qmul.ac.uk> [accessed Apr 23 2020].

399 Alexia Blanchard to Jacobus Boonen, November 24 1623, AAM, Engelse Benedictinessen, $12 / 1$.

${ }^{400}$ Tension appears to have existed between the two even before Percy was abbess; she wrote that when she was prioress (1613-1616) Chambers had "rebuked her for trying to limit talking during silent hours," Goodrich, "Authority, Gender, and Monastic Piety," 96.

${ }^{401}$ Goodrich, "Authority, Gender, and Monastic Piety," 97.
} 
removed from what she judgeth best." ${ }^{\prime 42}$ Other nuns commented on the personalities of Mary Percy and Father Chambers. Teresa Gage noted that Chambers was of "very rough condition...so sowre in confetion that hee dishartith devrs from making ther contienc knowen to him, for my part I have not confessed to him this to years." ${ }^{403}$ Regarding Percy, Mary Vavasour wrote that the abbess had a volatile personality, was prone to “extream passion" and frequently spoke "very freely \& bitterly of her discontents against F: Chambers." ${ }^{404}$ This suggests that the early conflict between Percy and Chambers was a “simple clash of personalities," having little to do with spiritual direction. ${ }^{405}$

But the controversy quickly escalated. From its foundation, the Brussels house had a close association with the Jesuits, who assisted the convent both spiritually and economically. In fact, Mary Percy learned Ignatian spirituality from Jesuit John Gerard, who also assisted her in 1593 when she decided to travel to the continent and become a nun. ${ }^{406}$ At first, Percy intended to join a continental convent but she was ultimately convinced by another Jesuit, William Holt, to establish the first English convent instead ${ }^{407}$ Commenting on the important role of the Jesuits in the convent, Potentiana Deacon wrote, "most or all of us have bene sent hether by the fathers of the Societye and since the begining of the monasterie have bene derected by them, for matter of meditation and the spirituall exercise." 408 However, the convent's statute limited the role of Jesuits by making them extraordinary confessors, meaning that they could provide spiritual

\footnotetext{
${ }^{402}$ Lucy Knatchbull to Jacobus Boonen, AAM, Engelse Benedictinessen, 12/2.

${ }^{403}$ Teresa Gage to Jacobus Boonen, AAM, Engelse Benedictinessen, 12/2.

${ }^{404}$ Mary Vavasour to Jacobus Boonen, AAM, Engelse Benedictinessen, 12/1.

${ }^{405}$ Goodrich, "Authority, Gender, and Monastic Piety," 92.

${ }^{406}$ Goodrich, "Authority, Gender, and Monastic Piety," 94-95.

${ }^{407}$ Goodrich, "Authority, Gender, and Monastic Piety," 94.

${ }^{408}$ Potentiana Deacon to Jacobus Boonen, August 26, AAM, Engelse Benedictinessen ,12/2.
} 
direction and hear confessions but only with the permission of the abbess and ordinary confessor. ${ }^{409}$ The presence of multiple authority figures within the convent clearly made Brussels a "fertile ground for power struggles over spiritual direction." 410 The list grew even longer when Father Francis Ward arrived at the convent in 1622 as a second ordinary confessor. ${ }^{411}$

At this point, letter writing and factionalism increased exponentially. As Jaime Goodrich has noted, during this conflict almost $70 \%$ of the Brussels choir nuns produced letters "offering either glowing commendations or scathing critiques of Ward," and many others also wrote in defence of Father Chambers. ${ }^{412}$ In 1623 alone, one nun, Potentiana Deacon, wrote ten letters to the Archbishop pleading with him on Chambers' behalf. ${ }^{413}$ There was also a notable breakdown between the younger, newly professed nuns who supported Ward and Percy, versus the senior nuns, most of whom held monastic offices, who opposed Ward. ${ }^{414}$ Commenting on the position of Ward at the convent, Mary Roper wrote that, "now that her Ladys hath another confessor... shee doth wholy neglect Fa: Chambers, taking all her advice from Mr Ward." ${ }^{15}$ Roper also wrote about Ward's qualification as confessor, saying that he was "not one that sheweth any great fittness for

\footnotetext{
${ }^{409}$ For more on the differences between ordinary and extraordinary confessors, and the limitations imposed on the latter see Goodrich, "Authority, Gender, and Monastic Piety," 95-96 and Murphy, "Language and Power in an English Convent in Exile," 4-5.

${ }^{410}$ Goodrich, "Authority, Gender, and Monastic Piety," 96.

${ }^{411}$ Ward arrived after the convent petitioned the Archbishop of Mechelen to allow them to hold communion twice a week, Goodrich, "Authority, Gender, and Monastic Piety," 102.

${ }^{412}$ Goodrich, "Authority, Gender, and Monastic Piety," 103. One nun to defend Father Chambers was Elizabeth Southcott who wrote, "Father Chambers... hath imployed his best dayes with us, and taken great paynes, \& performed good service," Southcott to Jacobus Boonen April 231623 , AAM, Engelse Benedictinessen, 12/1.

${ }^{413}$ Goodrich, Faithful Translators, 170.

${ }^{414}$ Goodrich, "Authority, Gender, and Monastic Piety," 103.

${ }^{415}$ Mary Roper to Jacobus Boonen, April 9 1623, AAM, Engelse Benedictinessen, 12/2.
} 
the guiding of soules. ${ }^{416}$ Countering this claim in her own letter, Eugenia Poulton argued that "though it be true that he is a young in years, yet in pietie, judgment, and gravitie he seems not unequall to many much more antient." ${ }^{417}$ Significantly, although the nuns' opinions on Ward differed, letters allowed both of them, and others, to assert their perspectives over the convent's spiritual direction.

While many letters can be categorized as promoting either a pro-Ward or anti-Ward stance, the Jesuits did not escape the attention of the Brussels nuns' correspondence. In fact, some nuns wrote that they were upset that Ward (a secular priest) was offering the nuns the Spiritual Exercises, thus infringing on the Jesuits' role. ${ }^{418}$ The Jesuits' place at the convent was made even more precarious when the anti-Jesuit Anthony Champney was installed as the ordinary confessor in 1628, without the "consent of the convent's Chapter." ${ }^{19}$ On this point, Anne Healey remarked that:

"The imposition of a Ghostly $\mathrm{fa}^{\mathrm{r}}$ without the conventes Election hath made thinges Triplly worse then ever they were. I am advising whether the dismission of $\mathrm{Fa}^{\mathrm{r}}$ Chambers, or the Imposition of Doctor Champne be the grater ivell unto us; for by the first our distruction was begunn, and the second semes likly to consumm it." 420

\footnotetext{
${ }^{416}$ Mary Roper to Jacobus Boonen, April 9 1623, AAM, Engelse Benedictinessen, 12/2. Teresa Gage also echoed this warning over Ward's influence when she wrote, "for my part I think he wanteh experienc... and I have resun to thinke she [Percy] may deseve agreatur judgment and a much more exprienced persun then him," Gage to Jacobus Boonen, AAM, Engelse Benedictinessen, 12/2.

${ }^{417}$ Eugenia Poulton to Jacobus Boonen, April 11 1622, AAM, Engelse Benedictinessen, 12/2. ${ }^{418}$ Murphy, "Language and Power in an English Convent in Exile," 7. One nun wrote that Ward should not "give the spiritual exersise to any," Aurea James to Jacobus Boonen, AAM, Engelse Benedictinessen, 12/2.

${ }^{419}$ Walker, Gender and Politics in Early Modern Europe, 139.

${ }^{420}$ Anne Healey to Jacobus Boonen, AAM, Engelse Benedictinessen, 12/1. Another nun, Benedict Hawkins reiterated these concerns in one of her letters. She wrote, "I beseech your grace to favour mee, in not conforming my selfe to Docter Champne to confes att this time... I find it unpossiabl to enjoye the assistance of the societe whill he is our gostly father," Benedict Hawkins to Jacobus Boonen, February 17 1629, AAM, Engelse Benedictinessen, 12/1.
} 
Here, Healey draws upon the convent's past controversy (with Chambers and Ward) to highlight the gravity of the current situation with Champney. Healey's use of the word 'advise' is also notable as it indicates how she viewed her relationship to the addressee, the Archbishop. It suggests that she, and other Brussels nuns, recognized their own authority to comment on, and influence, the spiritual direction of the convent.

In addition to petitioning the Archbishop, the nuns filed suit in the Roman curia protesting the appointment of Champney. ${ }^{421}$ While some nuns used their writing to focus on ousting Champney, others concentrated on the threat posed by the Jesuits to the convent. For example, Anne Ingleby wrote to the Archbishop to give her opinion on the Jesuits' influence, claiming "the unquiatnes so evidently incresed every time... [they] doth but cum nere us \& I can compare it to nothing so fittly then that every time they cum they poure great quantity of oille upon sum great flame for the subvertion $\&$ distruction of our monastery." 422 Even Mary Percy, who had relied upon the Jesuits since the convent's foundation, turned against them because they had not supported her during the conflict with Chambers and Ward. ${ }^{423}$ In 1628, Percy placed the blame for the convent's earlier problems solely on the Jesuits, negating any culpability for her own problems with Chambers. ${ }^{424}$ Percy wrote at this time, "it is playn \& sertain that the societie hath manteyned a faction many years against the cheef superior of this place."425 The letters produced during this dispute indicate that this was "not simply a question of clerical sympathies, nor of monastic obedience;" instead, it was a concerted effort on the behalf

${ }^{421}$ Goodrich, "Nuns and Community-Centered Writing," 298-299.

${ }^{422}$ Anne Ingleby to Jacobus Boonen, AAM, Engelse Benedictinessen, 12/1.

${ }^{423}$ Murphy, "Language and Power in an English Convent in Exile," 10.

${ }^{424}$ Goodrich, "Authority, Gender, and Monastic Piety," 112.

${ }^{425}$ Mary Percy to Jacobus Boonen, February 16 1628, AAM, Engelse Benedictinessen, 12/2. 
of women religious to exert their personal beliefs over the convent's direction. ${ }^{426}$ Letters allowed these views to be more than just passing thoughts.

While it is not surprising that women religious would be concerned with the state of their spiritual direction, what is significant is how they purposefully utilized letters to promote their perspectives. In 1638, Ethelard Smith utilized her letters to actively petition Archbishop Boonen "to consider whether we have not just cause to desier to have $\mathrm{y}^{\mathrm{e}}$ Jesuits perpetually banished [from] our Monasteri." ${ }^{\prime 27}$ In her correspondence, Smith makes two notable and strategic letter writing choices. First she employs the theme of spiritual decay to convince Boonen of the harmfulness of the Jesuits. She subsequently presents the pro-Jesuit arguments and then counters and undermines them with her own evidence. For example, she writes:

"But pechanc it may be answered $\mathrm{y}^{\mathrm{t}}$ we must of necessity have $\mathrm{y}^{\mathrm{e}}$ assistance of $\mathrm{y}^{\mathrm{e}}$ Jesuits for $\mathrm{y}^{\mathrm{e}}$ raysing of our temporall estate $\mathrm{w}^{\text {ch }}$ is now so decayed $\mathrm{y}^{\mathrm{t}}$ it is not soficient to maytaine us though live very poorely, and $\mathrm{y}^{\mathrm{t}} \mathrm{y}^{\mathrm{e}}$ Jesuits are $\mathrm{y}^{\mathrm{e}}$ only men of power who in England are able to doe us good. To this I answer $\mathrm{y}^{\mathrm{t}}$ were all this trew as I know it is most false $\mathrm{y}^{\mathrm{t}}$... were it better $\mathrm{y}^{\mathrm{t}}$ we perished temporally then eternally, and $\mathrm{y}^{\mathrm{t}}$ our Monastery ended $\mathrm{w}^{\text {th }}$ us then it should be mayd againe $\mathrm{y}^{\mathrm{e}}$ nurcery of rebellion." 428

In this way, Smith acknowledges the argument that the Jesuits are the only ones able to assist the house financially, but resists it by asserting that their influence would lead to the spiritual ruin of the convent.

Petitioning Archbishop Boonen to provide her with a Jesuit confessor, Teresa Gage utilized similar imagery of spiritual danger. Gage wrote, "I should never have lefte my country, the cumfort of my freinds, the contentmentes of the world... to have found but

\footnotetext{
${ }^{426}$ Walker, Gender and Politics in Early Modern Europe, 139-140.

${ }^{427}$ Etheldred Smith to Jacobus Boonen, April 21 1638, AAM, Engelse Benedictinessen, 12/3.

${ }^{428}$ Etheldred Smith to Jacobus Boonen, April 21 1638, AAM, Engelse Benedictinessen, 12/3.
} 
even the tenth part of these perillous straites wherin my soule is shut up here, not without danger of eternall ruien, for the want of that $\mathrm{w}^{\text {ch }}$ is meerely nessesary fo my salvation." 429 A letter written by Ursula Hewick during the initial Brussels conflict employed an equally deft construction. In her letter, Hewick shrewdly claimed not to have an opinion on Father Chambers' place at the convent, saying, "I doe no way solicet his stay or departure, for I am not partiall to any part but Gods, of which his divine Majestie hath made your Lo: the soveraine Judge what shall be best for us." ${ }^{230}$ And yet, in the next line Hewick continued, "but if his stay can be determined...the whole convent may injoy this priviledge... for our greater unitie with God \& each other." ${ }^{\prime 431}$ Here Hewick utilizes a passive tone while implicitly tying Father Chambers' presence to the spiritual prosperity of the convent. These examples illustrate that not only were letters the only way for women religious to present their opinions, but that they used them in a creative and calculated manner.

Discussions of Abbess Mary Percy's leadership also became a central theme in the correspondence of the Brussels nuns. The Brussels Statute stipulated that the abbess could inspect all letters or other types of mail; however, this power did not extend to letters addressed to ecclesiastical authorities. ${ }^{432}$ The statute specified that:

"If any of the Professed would at any tyme write to the Bishopp or Visitour, shee shall have free liberty to doe the same, and shee may deliver her letters to the Thourier, who may not...discover to any, that ever shee receaved any such letters... Neither may the Abbesse...either Directly, by any wayes... or outward shew of Countenances, hinder the free writing of their Religious to their Superiors." 433

\footnotetext{
${ }^{429}$ Teresa Gage to Jacobus Boonen, July 19 1638, AAM, Engelse Benedictinessen, 12/3.

${ }^{430}$ Ursula Hewick to Jacobus Boonen, April [1622/1623], AAM, Engelse Benedictinessen, 12/1.

${ }^{431}$ Ursula Hewick to Jacobus Boonen, April [1622/1623], AAM, Engelse Benedictinessen, 12/1.

${ }^{432}$ Brussels Benedictine Statutes, The First Parte, 37-38.

${ }^{433}$ Brussels Benedictine Statutes, The Third Parte, 8-9.
} 
Therefore, letters to Archbishop Boonen were "written with the desire and presumption of at least some level of privacy and secrecy." ${ }^{, 43}$ Despite this unambiguous command in the statute, it appears that Percy did try and suppress the nuns' correspondence, leading multiple women to write to Archbishop Boonen to complain of her abuse of power. ${ }^{435}$ In fact, during the first dispute, Frances Gawen explicitly wrote to the Archbishop that Percy was disobeying the statute, "both by wordes, countenances \& reprehensions," which had left the nuns with no freedom. ${ }^{436}$ Another witness, Lucy Knatchbull, commented that Percy told her "that if she could by chance meet $\mathrm{w}^{\text {th }}$ a letter sent to your $\mathrm{L}^{\text {pe }}$ she would make no scruple to open it...for she gave no cause of cumplaynts \& therfore they must needs write untruths. ${ }^{" 437}$ Elizabeth Southcott even asked Archbishop Boonen "to forbidd my Lady when she visiteth our celles not to reade $y^{\mathrm{e}}$ paperes that she by chance findeth written eyther conserninge our confessions, or anything to be sent to your $\mathrm{Lo}^{\mathrm{p}}$ or the visiter." ${ }^{\prime 438}$ This criticism had some merit, since Percy herself indicated in a letter that she, "foud in one of the celes of a principal officer divers letters," which she then took to read and locked up in a chest. ${ }^{439}$ Mary Vavasour further claimed that Percy was very "inquisitive" of what was being sent to the Archbishop and confessed that she had "a great dislike of wrighting \& speaking $\mathrm{w}^{\text {th }} \ldots$.. [the Archbishop] saing ther comes noe good therof...that all we seeke is but to represse her." ${ }^{\prime 40}$ These comments imply that

\footnotetext{
${ }^{434}$ Murphy, "Language and Power in an English Convent in Exile," 7. One example of this presumption of privacy can be seen a letter from Frances Gawen, when she writes "I have written these thinges in confidence as to a father," Gawen to Jacobus Boonen, April 23 1623, AAM, Engelse Benedictinessen, 12/1.

${ }^{435}$ Murphy, "Language and Power in an English Convent in Exile," 15.

${ }^{436}$ Frances Gawen to Jacobus Boonen, July 29 [1623], AAM, Engelse Benedictinessen, 12/1.

${ }^{437}$ Lucy Knatchbull to Jacobus Boonen, AAM, Engelse Benedictinessen, 12/2.

${ }^{438}$ Elizabeth Southcott to Jacobus Boonen, April 23 1623, AAM, Engelse Benedictinessen, 12/1.

${ }^{439}$ Mary Percy to Jacobus Boonen, AAM, Engelse Benedictinessen, 12/2.

${ }^{440}$ Mary Vavasour to Jacobus Boonen, AAM, Engelse Benedictinessen, 12/1.
} 
Percy was aware of, and deeply concerned with, the power of the letters and her own lack of control over the medium.

But one can also question if the trope of the paranoid abbess was strategically invoked by those looking to undermine Percy in order to further their own objectives within the convent. In her examination of these accusations, Jaime Goodrich has argued that nuns, "who held little to no official power at Brussels used gender stereotypes to legitimize their interventions in the convent's affairs." 441 Therefore, we can question whether allegations of abuse of authority levelled at Percy in these letters were genuine, or rather tactically employed to try and diminish her authority and credibility. The nuns attempted to exploit pre-existing anxiety over the convent as a space of "unregulated female power" when they consistently reiterated Percy's transgressions and presented her as an authoritarian. ${ }^{442}$ We can also question the motivations of Lucy Knatchbull, who was pro-Jesuit and wrote many times of Percy's detrimental leadership. Percy wrote that although Knatchbull was highly regarded and praised by many in the convent, she did not promote her to any higher office (such as prioress or mistress of the novices) because she found her "not so faithfull to the congergations, as I could have wished, too much yeldinge to libertie... her coucel $\&$ advis is much sought for of divers in the covet $\mathrm{w}^{\text {ch }} \mathrm{I}$ have not aproved." ${ }^{433}$ It is likely that Percy's jealousy over Knatchbull's influence resulted in her failure to promote Knatchbull. This in turn fuelled Knatchbull's negative

${ }^{441}$ Goodrich, "Authority, Gender, and Monastic Piety," 94.

${ }^{442}$ Goodrich, "Authority, Gender, and Monastic Piety," 101.

${ }^{443}$ Mary Percy to Jacobus Boonen, AAM, Engelse Benedictinessen, 12/2. 
portrayal of Percy in her own letters. ${ }^{44}$ In this way, personal animosity - rather than sincere concern for the convent or spiritual direction - could have been the true, covert motivation of the letter-writing campaign. ${ }^{445}$

Despite the numerous disparaging comments on Percy's leadership, she was not removed as abbess. Nonetheless, allegations of her controlling and paranoid behaviour continued to be deployed in the late 1620 s and 1630s. In 1638, Teresa Gage wrote, "I earnestly desir that those papers $\mathrm{w}^{\mathrm{ch}}$ are of mine in $\mathrm{y}^{\mathrm{m}}$ Ladis hands may be delivered unto your $\mathrm{Lo}^{\mathrm{p}}$ and that your $\mathrm{Lo}^{\mathrm{p}}$ will vouchsafe to cumand this to be dune $\mathrm{w}^{\text {th }}$ out delay for the lose of them douth exseedingly increse my afficiton." 446 Further, while letters allowed accusations such as these to be made against Percy, they also provided women religious a medium of self-defence. For example, Percy frequently used her letters to defend herself from complaints and accusations. In one letter she wrote, "I beseeche your $\mathrm{Lo}^{\mathrm{sp}}$ to doe me the favour...that my auswer may be pmitted...\& give me leave to defed my self in some sort agaist thos strang imputations that are layd against me." 447 This passage represents the intrinsic duality of the letters produced during conflict: valuable as a tool of selfdefence and a resource to rally support, they simultaneously fueled division.

\footnotetext{
${ }^{444}$ Goodrich states that Percy and Knatchbull appear to have had a strained relationship for many years, and Percy was suspicious that the Jesuits and other outsiders "intended Knatchbull to be Percy's replacement or co-abbess," "Authority, Gender, and Monastic Piety," 100. Interestingly, Knatchbull and seven other nuns, under Jesuit direction, attempted to found a new convent in Louvain in 1609 but were unsuccessful and returned to Brussels.

${ }^{445}$ Another example that shows personal animosity was rife at this convent comes from a letter from Ursula Hewicke. She writes that Percy threatened to send her to the new Cambrai convent because "she heard that there was a muttering of a strang thing in the congregation, \& that I [Hewick] was the authour of it." Hewicke used her letter to the Archbishop to plead with him not give his consent to this move. Hewicke to Jacobus Boonen, October 23, 1623, AAM, Engelse Benedictinessen, 12/1.

446 Teresa Gage to Jacobus Boonen, April 15 1638, AAM, Engelse Benedictinessen, 12/3.

${ }^{447}$ Mary Percy to Jacobus Boonen, AAM, Engelse Benedictinessen, 12/2.
} 
The dissemination of gossip and rumour, such as the accusations against Percy, was a strategic tool that women religious utilized in their letters. ${ }^{448}$ In fact, gossip and rumour during the early modern period can be understood as a form of currency where "the same information might be employed to conflicting ends by different parties." 449 But more relevant perhaps to the conventual context, gossip "was often used as an indirect, occasionally subversive, form of... action, by people who were otherwise powerless to enact change in communal relations." ${ }^{450}$ A few examples from Brussels hint at the use of epistolary gossip and rumour in this way. In 1624, for instance, allegations of witchcraft were made against Margerie Cotton. In one letter, Anne Ingleby wrote that Cotton should be "very searously examined" since she feared that Cotton dabbled in the dark arts of witchcraft. ${ }^{451}$ Notably, Cotton left Brussels in 1624 after she was found to be unsuitable, which suggests gossip played a significant role in her ousting. Further, in their individual letters, Lucy Knatchbull and Teresa Gage both claimed that the convent school (used to

\footnotetext{
${ }^{448}$ The word 'gossip', dated from the early seventeenth century, has been defined as: "to talk idly, mostly about other people's affairs; to go about tattling," and rumour refers to "general talk or hearsay, not based on definite knowledge," quoted in Claire Walker, "Whispering Fama: Talk and Reputation in Early Modern Society," in Fama and Her Sisters: Gossip and Rumour in Early Modern Europe, ed. by Heather Kerr and Claire Walker (Turnhout, Belgium: Brepols, 2015), 1215. For historical scholarship on gossip and rumour see: Max Gluckman, "Gossip and Scandal," Current Anthropology 4, no.3 (1963): 307-316; Sally Engle Merry, "Rethinking Gossip and Scandal," in Toward a General Theory of Social Control, ed. by Donald J. Black (London: Academic Press, 1984), 271-302; and Claire Walker, "Securing Souls or Telling Tales? The Politics of Cloistered Life in an English Convent," in Female Monasticism in Early Modern Europe: an Interdisciplinary View, ed. by Cordula van Wyhe (Burlington, VT: Ashgate, 2008), 228-232.

${ }^{449}$ Claire Walker and Heather Kerr, "Introduction: New Perspectives on Fama," in Fama and Her Sisters Gossip and Rumour in Early Modern Europe, ed. by Heather Kerr and Claire Walker (Turnhout, Belgium: Brepols, 2015), 2.

${ }^{450}$ Walker and Kerr, "Introduction: New Perspectives on Fama," 2.

${ }^{451}$ Anne Ingleby to Jacobus Boonen, AAM, Engelse Benedictinessen, 12/1. It appears Cotton had previously accused some women who had left the monastery of being witches, but it was Ingelby's opinion that Cotton "had som intangilment $\mathrm{w}^{\text {th }}$ such artes as she hath aftermed was sayed of others."
} 
train novices) appeared to be haunted by spirits caused by the Mistress of Novices, Agnes Lenthall, who was "sayd to have ben long subject to such molestations." 452 As Claire Walker has stated, "by unleashing scandalous information...disempowered nuns attempted to regain control over those aspects of monastic governance in which they could legitimately participate," such as the profession of new members or the election of offices. ${ }^{453}$ Therefore, while these letter writers may have truly believed in the witchcraft and haunted spirits they alleged, it is more compelling to question whether these acts were exaggerated, or entirely fabricated, in order to exert control and disparage their opponents' reputation. ${ }^{454}$

Gossip and rumour was also utilized against Father Francis Ward, who was accused in multiple letters of inappropriate relations with his penitents. Lucy Knatchbull alleged, in detail, an account of one woman, Mary Philips, who Ward would often take "by the chine, or...by the hand,... [and] say...I doe love the above all wimen of the world, and if I wear not a Priest and thou Religious, I would make the see how much I love thee and I would marie thee." 455 Potentiana Deacon echoed accusations of Ward's inappropriate behaviour when she wrote that he had bitten a purple silk ribbon off the bare arm of one

\footnotetext{
${ }^{452}$ Lucy Knatchbull to Jacobus Boonen, AAM, Engelse Benedictinessen, 12/2. Gage wrote that the Mistress had been "hanted with Sprites" her whole life but "ther wear never so much aparanc of them as sinc shee was Mrs of the Scoole," Teresa Gage to Jacobus Boonen, AAM, Engelse Benedictinessen, 12/2.

${ }^{453}$ Walker, "Whispering Fama," 23.

${ }^{454}$ Regarding the allegations against Lenthall, Aurea James wrote that, "I think shee is not so fit for that plas as sum other if shee be changed I think D. Frances would be the fittest for that ofis," - by this quote we can see that those opposed to Lenthall clearly had a replacement, from their own side of the conflict, in mind, Aurea James to Jacobus Boonen, AAM, Engelse Benedictinessen, 12/2.

${ }^{455}$ Lucy Knatchbull to Jacobus Boonen, May 16 1623, AAM, Engelse Benedictinessen, 12/1. Knatchbull also wrote that Ward told the woman, "it was no sinne for Religious persones to kiss though of different sexe," a comment that, to Knatchbull, was very harmful. Jaime Goodrich has named this nun as Mary Philips; Goodrich, "Authority, Gender and Monastic Piety,” 106.
} 
of the nuns. ${ }^{456}$ Knatchbull also wrote that she was concerned for Philips since "the pore creature...is so weake, that when she faleth into the ocastion she hath not the strenght to resist the evill it draws her into." 457 Interestingly, but not surprisingly, Knatchbull ended the letter by imploring Archbishop Boonen to dismiss Ward - which suggests that this accusation served a larger purpose than simply concern for a fellow nun. In fact, it is possible that the nuns actively exploited the image of "lascivious priests" in their letters in order to secure Ward's removal. ${ }^{458}$ Employing such stereotypes provided women religious with "a key means of asserting moral authority within the cloister," which helped them to achieve their objectives. ${ }^{459}$

The accusations of Ward's inappropriate actions, or even Percy's tyrannical behaviour discussed earlier, can be viewed as strategic epistolary choices. As Claire Walker has argued, while there may have been "legitimate concerns about the targets of gossip, like Ward...it is likely that their failings provided convenient opportunities" for their opponents to exert control. ${ }^{460}$ One of the most shocking incidents to be captured by the Brussels correspondence comes from the letters of Barbara Gage, known in religion as Teresa. ${ }^{461}$ In her letters, she claimed that the spread of 'falsehoods' had led to physical

\footnotetext{
456 "the Religious tould me her selfe, that having a purple silke twist about her bare arme, he had bitten it of $\mathrm{w}^{\text {th }}$ his teeth," Potentiana Deacon to Jacobus Boonen, April 5, AAM, Engelse Benedictinessen, 12/2.

${ }^{457}$ Lucy Knatchbull to Jacobus Boonen, May 16 1623, AAM, Engelse Benedictinessen, 12/1.

${ }^{458}$ Goodrich, "Authority, Gender and Monastic Piety," 105-106. For more on this trope, see Frances E. Dolan, Whores of Babylon: Catholicism, Gender, and Seventeenth-Century Print Culture (Cornell: Cornell University Press, 1999), 89-94; Ulrike Strasser, State of Virginity: Gender, Religion, and Politics in an Early Modern Catholic State (Ann Arbor: University of Michigan Press, 2004), 70.

${ }^{459}$ Goodrich, "Authority, Gender and Monastic Piety," 110.

${ }^{460}$ Walker, "Securing Souls or Telling Tales?" 243.

${ }^{461}$ For more on Barbara Gage (BB082) see her entry in WWTN $<$ https://wwtn.history.qmul.ac.uk> [accessed Mar 24 2020].
} 
violence, not once, but twice, within the convent. In one of her letters from 1638, Gage detailed a violent altercation between her and Abbess Mary Percy. After being accused of speaking to some nuns opposed to Percy, Gage wrote that Percy, "in great passion runing at mee, $\mathrm{w}^{\text {th }}$ both her fistes together...hitt me an the mouth...my Lady flieng again at mee, touke the sleeve of our habett and in great passion roling it like a wispe, shaked and pulled itt, as if she wold have pulled me abote the rowme, or throwen mee to the grownd. ${ }^{\prime 462}$ Gage apparently did not hit Percy back, instead, she claims to have said "Madam I have but alittill haier on my heade, but if it please you to drage mee aboute the rowme by itt, $\mathrm{w}^{\text {th }}$ the grace of god I shall be able to support it." ${ }^{\text {"63 }}$ This incident, and Gage's own peculiar response to being physically assaulted, reiterates the idea that we cannot take what is written in letters at face value. ${ }^{464}$ Optimistically, this letter provides the 'truth' from Gage's perspective, but it could also be a stratagem used to further Gage's personal motives. In fact, Bronagh Ann McShane has argued that Gage was a "key agitator in the convent disputes" and 17 nuns referred to her in their letters as a "divisive individual who incited discord." ${ }^{\prime 65}$ While Gage may be an unreliable narrator, her letters remind us that correspondence was carefully constructed and had explicit, albeit sometimes hidden, motivations.

\footnotetext{
${ }^{462}$ Teresa Gage to Jacobus Boonen, April 15 1638, AAM, Engelse Benedictinessen, 12/3.

${ }^{463}$ Teresa Gage to Jacobus Boonen, April 15 1638, AAM, Engelse Benedictinessen, 12/3.

${ }^{464}$ Gage also described another altercation she had, this time with Prioress Anna (Agnes) Lenthall in June 1638, after she claimed Lenthall spoke "falsehoods that day in Chapter" against her. During this incident Gage wrote that Lenthall "thrust her hand to my face in great anger and hurt one of [my] Eyes," to which Gage responded by giving her a blow, or two, to the head as Lenthall walked away. Teresa Gage to Jacobus Boonen, June 9 1638, AAM, Engelse Benedictinessen, $12 / 3$.

${ }^{465}$ McShane, "Visualising the Reception and Circulation of Early Modern Nuns' Letters," 10.
} 
The correspondence produced during the Brussels controversies exemplifies the power of letters to spread gossip and rumour, whether credible or not. As previously mentioned, reputation was extremely important to the survival of English convents in exile. In fact, Anne Healey wrote in one letter, "the only cause why I chewesed this monastery, was the name it had of perfection and spirituallity above others." ${ }^{\text {" } 66}$ While letters were a powerful tool to advance a positive reputation, they could conversely spread gossip, rumour and other negative news that harmed a convent's reputation. ${ }^{467}$ The letters of the Brussels nuns in the early 1620s show that they were keenly aware that internal disputes affected their external reputation. For instance, Scholastica Smith wrote that Percy claimed to receive "a most desgraceful letter" from England, comparing the convent to the "ruines of Troy." 468 Smith's concern for the comparison prompted her to urge Archbishop Boonen to investigate and take the necessary steps to reform them. ${ }^{469}$ Smith also requested that if he found them innocent of any wrongdoing that he write to their friends abroad so that the convent "may be freed from the slander $\&$ the scandal of others. $"{ }^{470}$ Further, Smith was not the only nun concerned with the comparison to Troy. During the same month, Potentiana Deacon wrote pleadingly to Archbishop Boonen that, "I feare this monasterie wilbe much disgraced and impoverished therby, and we shalbe in daunger to loose our best freinds, unless your Lo: ${ }^{\mathrm{p}}$ undertake the busines, and...reduce us

\footnotetext{
${ }^{466}$ Anne Healey to Jacobus Boonen, AAM, Engelse Benedictinessen, 12/1.

${ }^{467}$ Walker, "Whispering Fama," 18.

${ }^{468}$ Scholastica Smith to Jacobus Boonen, December, AAM, Engelse Benedictinessen, 12/1.

${ }^{469}$ Smith wrote, "my petition is most humbly to beseeche your Honor that you will please to commande my Lady to deliver that letter onto you wherby your Lordshep may more cleerly understand the estate of our congrecation... you may the better judg whether the faulte be in my Lady or the convent or in bothe \& if you shaul find these reportes true then you will take order to refome us." Scholastica Smith to Jacobus Boonen, December, AAM, Engelse Benedictinessen, $12 / 1$.

${ }^{470}$ Scholastica Smith to Jacobus Boonen, December, AAM, Engelse Benedictinessen, 12/1.
} 
under due Religious peace and discipline, from $\mathrm{w}^{\mathrm{ch}}$ we are fallen." ${ }^{471}$ And in fact, the nuns were right to be worried. As Anne Healey wrote, after the events of the initial conflict, "it is impossible...to revock those scandalous infamys which England is so full of concerning us wher formerly the Renowne of this Covents veartue and pfection was so Glorious, that even the heritickes themselves did honour it." ${ }^{472}$ These letters show that women religious used correspondence to facilitate the movement of news, credible or not, in and out of their convents. These epistolary appeals for assistance exemplify the dual nature of letter writing in convent contexts. Letters could be a positive tool for women religious, such Deacon and Smith, by allowing access to external support networks. But they could also have deleterious effects as they allowed conflict and harmful rumours to reach wider audiences.

The correspondence produced at Brussels demonstrates the complexity of women religious' epistolary activity. While rooted in concerns about monastic governance and spiritual leadership, the letters reflect a fractured community that utilized equally diverse letter writing techniques. As the nuns' only recourse, letters allowed them to access external support in the Archbishop of Mechelen, and assert their often opposing perspectives. The conflicts also encouraged the Brussels nuns to utilize epistolary space for self-serving ends. Employing submissive language, stereotypes (of the tyrannical abbess or salacious priest), as well as rumours and gossip, women religious constructed letters to fit their personal motivations and aims. As one nun argued, the conflicts become so extreme in the convent that it was "impossible ether for the one part, or other to live

\footnotetext{
${ }^{471}$ Potentiana Deacon to Jacobus Boonen, December 13, AAM, Engelse Benedictinessen, 12/1.

${ }^{472}$ Anne Healey to Jacobus Boonen, AAM, Engelse Benedictinessen, 12/1.
} 
like true religious persons." ${ }^{473}$ Letters, rather than repairing these internal divisions, further fuelled the flames.

${ }^{473}$ Barbara Ducket to Jacobus Boonen, March 5 1629, AAM, Engelse Benedictinessen, 12/1. 


\section{Chapter 3: Political Correspondents, Diplomatic Correspondence}

\section{"By the greatness of my duty": Mary Knatchbull's Epistolary Network}

In 1659, Mary Knatchbull, abbess at the Benedictine convent in Ghent, stated: "it

will be the best of my felissityes if any thinge I doe or can ever be able to doe may prove a service to his $\mathrm{Ma}^{\text {sty }} . " 474$ This statement of enthusiastic service was written in one of Knatchbull's many letters to Sir Edward Hyde, a chief advisor of Charles II. ${ }^{475}$ But Hyde was by no means Knatchbull's only correspondent; she also sent and received letters for the Duke (later Marquess) of Ormonde and others hoping to restore Charles II as the King of England. ${ }^{476}$ At first glance Knatchbull, a cloistered nun, may appear out of place among formidable political men. However, the abbess's correspondence, spanning from the mid-1650s to early-1660s, sheds light on how women religious actively engaged in the political realm in England and the Continent. ${ }^{477}$ To date, historical scholarship on Mary Knatchbull has primarily used her letters as historical evidence, rather than critically investigating the letters as the subject. ${ }^{478}$ Claire Walker and Caroline Bowden

\footnotetext{
${ }^{474}$ Knatchbull to Hyde, 24 June 1659, Bodleian Library, Oxford, Clarendon State Papers, JuneJuly 1659, MS. Clarendon 61, fol. 191. For more on Mary Knatchbull (GB118) see her entry in WWTN < https://wwtn.history.qmul.ac.uk> [accessed May 10 2020].

${ }^{475}$ Hyde was Lord Chancellor from 1660 to 1667, for a more information on Edward Hyde see Paul Seaward, "Hyde, Edward, first earl of Clarendon," Oxford Dictionary of National Biography. 04 Oct. 2008; https://doi.org/10.1093/ref:odnb/14328.

${ }^{476}$ For a brief overview of the Duke of Ormonde see Toby Barnard, "Butler, James, first duke of Ormond," Oxford Dictionary of National Biography. 04 Oct. 2008;

https://doi.org/10.1093/ref:odnb/4191. For a selection of historical scholarship on the restoration of Charles II see: Neil H. Keeble, The Restoration: England in the 1660s (Oxford : Blackwell, 2002); Jennifer S. Uglow, A Gambling Man: Charles II and the Restoration, 1660-1670 (London: Faber and Faber, 2009); David Underdown, Royalist Conspiracy in England, 1649_ 1660 (New Haven: Yale University Press, 1960).

${ }^{477}$ Knatchbull's letters have been preserved over multiple collections, the largest of which is the Clarendon State Papers and Carte Papers Letters housed in the Bodleian Library, Oxford. Other letters relevant to this thesis include British Library, Letters to James II and Others with Cypher 1609-1688, Additional MS 21 483, and SP77/32 from the National Archives, Kent.

${ }^{478}$ For historical scholarship see: Caroline Bowden, "The Abbess and Mrs. Brown: Lady Mary Knatchbull and Royalist Politics in Flanders in the Late 1650s," Recusant History, 24 (1999):
} 
have both written about Knatchbull's role in royalist politics, her ability to operate in both the convent and the royal court as well as her motivations. And yet, these studies have downplayed the importance of letters as the tool that allowed her to be successful, and her role in carefully and skillfully constructing her correspondence. Knatchbull served as an intermediary for powerful men, transporting letters through her convent. But she was also a confidant who increasingly asserted her perspective on the intelligence she gathered. Letters gave the abbess a medium, and opportunity, to position herself in external spheres of influence which were otherwise inaccessible. An analysis of her correspondence illuminates how women religious tactically utilized letter writing as an important tool of diplomacy and alliance building. Letters allowed Knatchbull to craft a public persona, engage with the political world, and position her convent to reap the rewards of her efforts.

The Ghent Benedictine convent was founded as an offshoot of the Brussels house in 1624. One of the founders was Mary Knatchbull's aunt, Lucy Knatchbull, who was also the first abbess. The Knatchbulls came from a prominent Catholic gentry family, who sent multiple family members, male and female, to the continent to pursue religious vocations. ${ }^{479}$ In the seventeenth century, six Knatchbull women professed at the Ghent

288-308; "The Role of Mary Knatchbull in the English Benedictine Foundations of the Seventeenth Century," Magistra 8, no. 1 (2002): 26-52; Claire Walker, "Prayer, Patronage, and Political Conspiracy: English Nuns and the Restoration," The Historical Journal 43, no. 1 (2000): 1-23; "Crumbs of News: Early Modern English Nuns and Royalist Intelligence Networks," Journal of Medieval and Early Modern Studies 42, no. 3 (2012): 635-655.

${ }^{479}$ Walker, "Prayer, Patronage, and Political Conspiracy," 4; Caroline Bowden, "Knatchbull, Mary (1610-1696), Abbess of the Convent of the Immaculate Conception, Ghent," Oxford Dictionary of National Biography. 23 Sep. 2004; https://doi.org/10.1093/ref:odnb/66452; Bowden, "The Abbess and Mrs. Brown," 290. 
convent, two of whom would go on to become abbess. ${ }^{480}$ One could characterize the Knatchbull nuns as part of a conventual 'dynasty.' After professing in 1628 with her sister Margaret, Mary Knatchbull held a number of monastic offices, including novice mistress, dean, and prioress before becoming abbess. ${ }^{481}$ In 1650 , she was elected abbess and remained in the position for 46 years (until her death in 1696); during this time she was a prolific letter writer. ${ }^{482}$ Knatchbull quickly recognized that contact with the outside world was both inevitable and necessary. During her first few years in office, Knatchbull sent a public petitionary letter to the citizens of Ghent, pleading for assistance after the convent suffered financially as a consequence of the English civil war. ${ }^{483}$ Knatchbull began this letter, "being humbly to expose unto the charity of $\mathrm{y}^{\mathrm{e}}$ citty the distress of our Community, wee desire it may be in the first place understood and considered $\mathrm{y}^{\mathrm{t}}$ this greate poverty hath occurred through no excess of ours, but from the common calamnity of $\mathrm{o}^{\mathrm{r}}$ Nation." 484 This letter highlights the permeable boundary between convents and the outside world and speaks to the impact of English political events on those in exile. ${ }^{485}$

\footnotetext{
${ }^{480}$ Walker, "Prayer, Patronage, and Political Conspiracy," 4; The third Knatchbull to become abbess was Mary's great niece, also named Mary, who was abbess from 1711 until 1727, see her entry Mary Knatchbull (GB119) in WWTN < https://wwtn.history.qmul.ac.uk> [accessed June 24 2020].

${ }^{481}$ Bowden, "Knatchbull, Mary (1610-1696),"; Mary Knatchbull (GB118) in WWTN $<$ https://wwtn.history.qmul.ac.uk $>$ [accessed June 24 2020].

${ }^{482}$ Lux-Sterritt, English Benedictine Nuns in Exile in the Seventeenth Century: Living Spirituality (Manchester: Manchester University Press, 2017), 51.

${ }^{483}$ For more on the Ghent convent's economic situation at this time see, Lux-Sterritt, English Benedictine Nuns in Exile in the Seventeenth Century, 80-81; Caroline Bowden also briefly mentions this letter in "The Abbess and Mrs. Brown," 291.

${ }^{484}$ Stafford, Oulton Abbey Archives (OA), MS G.11, Appeal to the Citizens of Ghent: 'An account of the necessitys of the community'; I am grateful to Jaime Goodrich for sharing her photographs of this letter with me.

${ }^{485}$ For more on how English convents suffered financially during this period see Walker, Gender and Politics in Early Modern Europe, esp. chap. 3: 'The Monastic Economy: Prayer and Manual Labour', pp. 74-101, as well as Claire Walker, "Combining Martha and Mary: Gender and Work in Seventeenth-Century English Cloisters," The Sixteenth Century Journal 30, no. 2 (1999): 397418.
} 
But it also shows that Knatchbull knew how to strategically construct her letters. In this case, she purposefully places the blame for the 'poverty' solely on external factors, and portrays her convent as an innocent victim of circumstance. This was epistolary choice designed to elicit as much sympathy as possible.

After the English Civil War, sparked in 1642 by Charles I and lasting until 1651, Charles II went into exile. ${ }^{486}$ Originally the royal court was located in France, but moved to Cologne in 1654 and Bruges (part of the Spanish Netherlands) in 1656 - which is when the first letters between Knatchbull and the royalists were exchanged. ${ }^{487}$ As Claire Walker has argued, English nuns' persistent existence made them "veterans of religious and political subversion" and thus well positioned to play a role in restoration efforts. ${ }^{488}$ Even before Mary Knatchbull became abbess, the Ghent convent had begun to build a favorable relationship with Charles II and the royal court. ${ }^{489}$ Other English convents also supported the royalist cause. The Bruges Augustinians, for example, donated 1,000

\footnotetext{
${ }^{486}$ As Claire Walker has neatly summarized, "the exodus of cavaliers from England during the Civil Wars...created a diaspora of exiled royalists scattered through a dozen or so Continental countries. The émigrés included the former king's queen and children, as well as many of his ministers, soldiers, and supporters...their loyalty to the monarchy led many to embrace conspiracy in a bid to... return to their homeland under the rule of...Charles I's heir, the future Charles II." Walker, "Crumbs of News," 642.

${ }^{487}$ Bowden, "The Abbess and Mrs. Brown," 293-295, where Bowden explains that shifting political alliances caused the royal court to move around the continent.

${ }^{488}$ Walker, "Crumbs of News," 648. For more on the relationship between the monarchy and English convents see, Bowden, "The Abbess and Mrs. Brown," 288-307; Lux-Sterritt, English Benedictine Nuns in Exile in the Seventeenth Century, 124-128; Claire Walker, "Loyal and Dutiful Subjects: English Nuns and Stuart Politics," in Women and Politics in Early Modern England, 1450-1700, ed. by James Daybell (Burlington, VT: Ashgate, 2004), 230-237.

${ }^{489}$ Charles II first visited Ghent in 1650, and when the abbess Mary Roper fell ill he sent his private doctor to treat her; Walker, "Prayer, Patronage, and Political Conspiracy," 3.
} 
florians to the exiled king. ${ }^{490}$ Knatchbull's royalism was thus far from unique. ${ }^{491}$ Rather, she stands out because of her extensive and deliberate use of epistolary activity to participate in the secular world.

As James Daybell has remarked, "the world of diplomacy, statecraft and intelligence gathering... has traditionally been viewed as...a female-free zone." ${ }^{492}$ And yet, there has been increasing historical scholarship on the role of secular women as 'invisible' political and diplomatic agents. ${ }^{493}$ Secular women were often able to exert influence through their husbands or via kinship networks that offered an outlet for indirect power. ${ }^{494}$ Even negative attitudes about women's abilities could be used to their advantage as it "made them useful to men as emissaries, mediators, and spies." ${ }^{495}$ In this way, power (or the ability to impact or control events) can be understood as fluid. Women who were excluded from the public sphere were able to exert influence in the private or domestic sphere. ${ }^{496}$ This type of activity was more uncommon for women

\footnotetext{
${ }^{490}$ Walker, "Prayer, Patronage, and Political Conspiracy," 6.

${ }^{491}$ Interestingly, as Claire Walker has commented, "it is not clear how supportive the rest of the Ghent Benedictines were of their abbess's engagement in Stuart politics. Most nuns shared Mary Knatchbull's royalist sentiments and would have agreed with her goals, if not her actions." Claire Walker, "Recusants, Daughters and Sisters in Christ: English Nuns and their Communities in the Seventeenth Century," in Women, Identities and Communities in Early Modern Europe, ed. by Stephanie Tarbin and Susan Broomhall (Aldershot: Ashgate, 2008), 71.

492 James Daybell, "Gender, Politics and Diplomacy: Women, News and Intelligence Networks in Elizabethan England," in Diplomacy and Early Modern Culture, ed. by Robyn Adams and Rosanna Cox (London: Palgrave Macmillan, 2011), 101.

${ }^{493}$ For selection of this scholarship see: Nadine Akkerman, Invisible Agents: Women and Espionage in Seventeenth-Century Britain (Oxford: Oxford University Press, 2018); James Daybell, "Gender, Politics and Diplomacy," particularly pp.101-107, 111-113; Sara Mendelson and Patricia Crawford, Women in Early Modern England, 1550-1720 (Oxford: Oxford University Press, 1998); Claire Walker, "Crumbs of News," 636-637.

${ }^{494}$ This argument is largely based on a Foucauldian theory of the diffuse nature of power, which argues that "power can be fragmented among many operators whose concerted effort combines to achieve the desired goal," Walker, "Prayer, Patronage, and Political Conspiracy," 3.

${ }^{495}$ Mendelson and Crawford, Women in Early Modern England, 413.

${ }^{496}$ Walker, Gender and Politics in Early Modern Europe, 103.
} 
religious. Given their restricted mobility and the absence of husbands and male relatives, women religious were further removed from positions of influence than secular women. Nuns were regarded by English authorities as "hapless, harmless creatures" who posed no serious political threat. ${ }^{497}$ In fact, some English monks in exile were known to transport letters, and were theoretically better positioned to facilitate this activity since they were not cloistered. ${ }^{498}$ However, as Claire Walker has argued, "the sheer volume of letters...points to the enclosed nun, Mary Knatchbull, as the most significant recusant religious agent between 1658 and the Restoration." ${ }^{499}$ But while Mary Knatchbull is the most overt example of a nun who actively inserted herself into the political sphere, she was not the only one. Mary Rose Howard, prioress at the Dominican convent in Brussels, operated a postal network for James Francis Edward Stuart in the $1720 \mathrm{~s} .{ }^{500}$ Similar to Knatchbull, Howard transported letters and news between the Jacobites in England and the royal court in exile, establishing herself as a "trustworthy ally."501 Through letters, women, such as Knatchbull and Howard, were able to integrate themselves into political and diplomatic networks that otherwise would have been unreachable.

As has previously been established, convents relied on outside connections in order to remain economically stable. Discussing the beginning of her epistolary network Knatchbull remarked, "longe since upon account of my owne little affaires in England I

\footnotetext{
${ }^{497}$ Lux-Sterritt, English Benedictine Nuns in Exile in the Seventeenth Century, 115. Claire Walker has argued that these "dismissive attitudes" ultimately benefited nuns and made them more attractive as political allies, Walker, "Loyal and Dutiful Subjects," 238.

${ }^{498}$ One such example is Abbott Placid Gascoigne who conveyed news from Germany to Edward Hyde, Walker, "Crumbs of News," 643-644.

${ }^{499}$ Walker, "Crumbs of News," 644.

${ }^{500}$ Walker, "Loyal and Dutiful Subjects," 238. For more on Mary Rose Howard (BD040) see her entry in WWTN < https://wwtn.history.qmul.ac.uk> [accessed May 20 2020].

${ }^{501}$ Walker, "Loyal and Dutiful Subject," 238.
} 
had made a way for the safty of my corrispondence theither by some little bribes to all those who were able to assist therin." ${ }^{502}$ Knatchbull was abundantly aware of the value of epistolary communication, and astute enough to guarantee that her networks would be secure. As abbess she built up a range of contacts. She had numerous kinship and monastic contacts who appear to have readily shared news and intelligence with her. ${ }^{503}$ And she cultivated relationships with multiple continental merchants when her convent began crafting and selling artificial flowers for extra income. ${ }^{504}$ Contact with the exiled royal court and other political figures during the seventeenth and eighteenth centuries also became commonplace for many convents, not only those that were English. ${ }^{505}$ As Claire Walker has commented, convents were in no way "strangers to networks of power and governance, in certain instances they engaged actively in the politics of both Church and State." ${ }^{506}$ Interestingly, Knatchbull's letters indicate that she expected the King and other leading royalists to visit the Ghent convent. In one letter, writing "I hope his Ma'ty is going speedily for England and will pass this way, that wee may have the comfort to

\footnotetext{
${ }^{502}$ Knatchbull to Hyde, 24 June 1659, Bodl., MS Clarendon 61, fol. 191.

${ }^{503}$ For more on Knatchbull's contacts see Walker, "Crumbs of News," 645-646; Walker, "Prayer, Patronage and Political Conspiracy," 5; Bowden, "The Abbess and Mrs. Brown," 296.

${ }^{504}$ Walker, "Prayer, Patronage, and Political Conspiracy," 6.

${ }^{505}$ Walker, "Loyal and Dutiful Subjects," 228; Caroline Bowden, "General Introduction," in English Convents in Exile, 1600-1800: Volume 1. History Writing, ed. by C. Bowden (London: Pickering \& Chatto, 2012), xiv. For a selection of sources on European convents royal connections see Walker, Gender and Politics in Early Modern Europe, 104-106; Silvia Evengelisti, Nuns: A History of Convent Life 1450-1700 (Oxford: Oxford University Press, 2007); Magdalena S. Sanchez, "Where Palace and Convent Met: The Descalzas Reales in Madrid," The Sixteenth Century Journal 46, no. 1 (2015): 53-82.

${ }^{506}$ Walker, "Loyal and Dutiful Subjects," 239. For instance, Mary of Modena's relationship with Mary Caryll, abbess of the Dunkirk Benedictines, was discussed in Chapter 1. For more on Mary of Modena's relationships with women religious, including Mary Knatchbull, see Walker, "Loyal and Dutiful Subjects," 228-240. Further, the illegitimate daughters of Charles II and James II were both professed nuns with the Pontoise Benedictines, Caroline Bowden, "The English Convents in Exile and Questions of National Identity c.1600-1688," in British and Irish Emigrants and Exiles in Europe, 1603-1688, ed. by David Worthington (Leiden: Brill, 2010), 307-308.
} 
see him." ${ }^{507}$ And when an anticipated visit fell through, Knatchbull lamented, "yor passage to Bruxells... would have added a high holy day to this joyfull festivity and have given us much content." ${ }^{508}$ While Charles II visited the Ghent convent several times, it is important to recognize that these visits were never simply about entertaining the king. ${ }^{509}$ Relationships with the royal court were undeniably strategic. Knatchbull's close relationship with Charles II indicated the convent's prominent reputation, which was important for new recruits and potential benefactors. ${ }^{510}$ But it also provided the abbess herself with an opportunity to directly influence the royal court and to advance her personal ambitions.

Mary Knatchbull's correspondence is notable for her use of deferential language. Similar to the Brussels correspondence analyzed in Chapter Two, submissive language ultimately conceals the bold content and self-assured commentary in Knatchbull's letters. For example, Knatchbull once wrote to Ormonde, "I am troblesome to yo ${ }^{\mathrm{r}}$ Ex:cy beyound measure." ${ }^{11}$ Portraying herself as 'troblesome' follows conventional female epistolary tropes of humility and deference. ${ }^{512}$ And yet, the next part of Knatchbull's sentence reads, "but I am sure you can forgive a trespass $\mathrm{w}^{\mathrm{ch}} \mathrm{I}$ am led into only by the greatness of my duty and affection for yo $^{\mathrm{r}} \mathrm{Ex}^{\text {cyes }}$ service." ${ }^{513}$ In this way, Knatchbull excuses and justifies a likely perceived intrusion by framing it as part of her duty. Knatchbull often used a

\footnotetext{
${ }^{507}$ Knatchbull to [Hyde], 26 April 1660, Bodl., MS Clarendon 71, fol. 268.

${ }^{508}$ Knatchbull to Ormonde, Bodl., MS Carte 30, fol. 450.

${ }^{509}$ Walker, "Prayer, Patronage and Political Conspiracy," 14.

${ }^{510}$ Walker, "Prayer, Patronage and Political Conspiracy," 14.

${ }^{511}$ Knatchbull to Ormonde, 9 March 1660, Bodl., MS Carte 30, fol. 543.

512 James Daybell has examined early modern women's use of deferential language within familial letters in his article, "Gender, Obedience, and Authority in Sixteenth-Century Women's Letters," The Sixteenth Century Journal 41, no. 1 (2010): 49-67.

${ }^{513}$ Knatchbull to Ormonde, 9 March 1660, Bodl., MS Carte 30, fol. 543.
} 
deferential tone when writing about her service, in one instance writing, "if $\mathrm{yo}^{\mathrm{r}} \mathrm{Lo}^{\mathrm{tt}}$ have nay [sic] commands for me I will venture to send them as longe as you can finde me usefull." 514 This tactic is echoed in another of Knatchbull's letters when she writes, "my imprtunity is not an effect of dissidence but of experience $\mathrm{w}^{\text {ch }}$ hath given me so much assurance of $\mathrm{yo}^{\mathrm{r}}$ Graces greate favour to me and mine. ${ }^{" 515}$ Here, the abbess uses her relationship with Ormonde, whom she depicts as benevolent, to subtly defend any of her actions that might appear rebellious on account of her gender and religious identity.

Knatchbull clearly understood how to use epistolary language to build strong relationships. In fact, in one letter to Hyde, Knatchbull refers to him, rather informally, as her 'friend'. The abbess wrote:

"I esteeme $\mathrm{yo}^{\mathrm{r}} \mathrm{Lo}^{\mathrm{tt}}$ a true frind where you are pleased to alow the honer of that title, and a lover also of plaine dealling from persons of that quallity...my confidence so greate and reall in $\mathrm{yo}^{\mathrm{r}} \mathrm{Lo}^{\text {tts }}$ generous goodness that I presume to take a liberty $\mathrm{w}^{\text {th }}$ $\mathrm{yo}^{\mathrm{r}} \mathrm{Lo}^{\text {tt }} \mathrm{w}^{\text {ch }} \mathrm{I}$ could not adventure on $\mathrm{w}^{\text {th }}$ any whom I thought not truly my frinde (pardon me my Lord for persuming this title)." 516

This "tone of familiarity" that Knatchbull utilizes is an important part of her epistolary repertoire ${ }^{517}$ Knatchbull deliberately justifies her atypically bold behaviour by framing it as a consequence of her strong relationship with Hyde. Even after Knatchbull had established herself as a critical collaborator, she continued to cleverly downplay her role. In a letter to Sir Edward Nicholas, the abbess remarked, "my intelligence I assure you Sr is very inconsiderable. The world knowes I am a harty lover of his $\mathrm{Ma}^{\text {stys }}$ interests and upon that account finds are so charitable some times as tell me good nuse $\mathrm{w}^{\mathrm{n}}$ any is

\footnotetext{
${ }^{514}$ Knatchbull to Hyde, 12 October 1659, Bodl., MS Clarendon 67, fol. 99.

${ }^{515}$ Knatchbull to Ormonde, 20 May 1661, Bodl., MS Carte 31, fol. 191.

${ }^{516}$ Knatchbull to Hyde, 17 September 1659, Bodl., MS Clarendon 64, fol. 197

${ }^{517}$ Walker, Gender and Politics in Early Modern Europe, 111.
} 
stiring. $" 518$ Here, Knatchbull presents her intelligence as almost happenstance, rather than a result of the extensive and strategic network of contacts, and trust, that she had developed. These examples demonstrate that Knatchbull carefully constructed her letters to appear submissive and nonthreatening, while engaging in acts that overtly contradicted those qualities.

The news and intelligence that Knatchbull transported through her postal network was unsurprisingly political in content. Knatchbull conveyed information regarding English politics, troop movements, the actions of exiled royalists, and more. ${ }^{519}$ But Knatchbull did not simply pass letters through her convent; she actively commented upon and asserted her opinion on the content she was conveying. For example, when England closed its ports so no letters could be delivered, Knatchbull remarked that it proved, "they are in earnest in their divitions, such stoping of the ports not having been executed in any of the former dissolutions of government... No doubt this confused state of England...will give him [the King] greate advantage." ${ }^{520}$ A month later, Knatchbull commented again on the political situation in England, reiterating her view that this would be a favourable time for Charles II's restoration. ${ }^{521}$ This indicates that Knatchbull

\footnotetext{
${ }^{518}$ Knatchbull to Nicholas, 7 March 1658, National Archives, SP 77/32, fol. 41. Sir Edward Nicholas was Secretary of State to Charles II, Walker, "Crumbs of News," 642.

${ }^{519}$ Walker, "Crumbs of News," 644; Walker, "Prayer, Patronage and Political Conspiracy," 7-10. For example, in one letter from October 1659, Knatchbull provided news on peace talks between the English commonwealth and Spain, Knatchbull to Hyde, 4 October 1659, Bodl., MS Clarendon 65 , fol. 69. These talks appeared to have broken down a few weeks later and Knatchbull remarked that "all tends to warr and distruction," Knatchbull to Hyde, 24 October 1659, Bodl., MS Clarendon 67, fol. 154. This implies that Knatchbull was part of a very active and evolving news and intelligence network.

${ }^{520}$ Knatchbull to [Hyde], 5 November 1659, Bodl., MS Clarendon 66, fol. 37.

${ }^{521}$ Knatchbull wrote, "it seemes Monk is very high and contrary to their expectations in England and doth $\mathrm{w}^{\mathrm{t}}$ he can to devide the citty from the Army, Lockhard and Downing are both in London and every thinge apeeres to be in that disjoynted condission $\mathrm{w}^{\text {ch }}$ makes best for our Kings advantage," Knatchbull to [Hyde], 10 December 1659, Bodl., MS Clarendon 67, fol. 83.
} 
could not only interpret political events but was confident enough to express her opinion to Hyde.

While Knatchbull's hopes for the king's restoration may paint her as an optimist, she appears to have been highly pragmatic. In one of her letters, she remarked rather dryly, "good wishes and harty desires for his $\mathrm{Ma}^{\text {ttys }}$ service are liberally imparted $\mathrm{w}^{\text {ch }}$ accompanyed $\mathrm{w}^{\text {th }}$ no effects doe you little good." ${ }^{222}$ In another letter, the abbess gave her practical opinion regarding the significance of Cromwell's death a month earlier, writing, "I thinke...that though Crowells [sic] death were all wayes a blessing to us, it was in present sircumstances (as to dispositions att home in order to the kinge and his ministers) as little an one as it could be." 523 These examples highlight Knatchbull's ability to access news, interpret it, and impart her own opinions. In David Randall's book on early modern English news networks, he wrote, “women's participation...remained very slight...when they did take part...it was more often as recipients than as transmitters." ${ }^{\circ 24}$ But Mary Knatchbull's letters show that women were more than recipients, and took an active, if less obvious, role in politics and diplomacy.

In 1658, Mary Knatchbull wrote to Hyde, "my confidence gives me liberty to say any thinge and to [hope] you will pardon me therin." 525 The tone of Knatchbull's letters implies a deferential, submissive role, yet the content reveals the confidence she had in her analytical abilities. While early on in it appears that Knatchbull sent everything she received to Hyde, over time she increasingly summarized the letters' contents and only

\footnotetext{
${ }^{522}$ Knatchbull to Hyde, 24 October 1658, Bodl., MS Clarendon 59, fol. 110.

${ }^{523}$ Knatchbull to Hyde, 5 October 1658, Bodl., MS Clarendon 59, fol. 28.

${ }^{524}$ David Randall, Credibility in Elizabethan and Early Stuart Military News (London: Pickering \& Chatto, 2008), 54.

${ }^{525}$ Knatchbull to Hyde, 17 October 1658, Bodl., MS Clarendon 59, fol. 87.
} 
passed on news that she deemed most valuable. ${ }^{526}$ For instance, Knatchbull once wrote, in regards to the week's mail delivery, "I find nothine worth yo ${ }^{\mathrm{r}} \mathrm{Lo}^{\text {tts }}$ troble in reading it." 527 The fact that Knatchbull had confidence that she could evaluate what news was 'worth' sending to Hyde and Ormonde illustrates that she was keenly confident in her own abilities and intellect.

Knatchbull was also quick to admit when she did not understand something. In one of her letters to Hyde, Knatchbull transcribed a portion of a letter received from a 'Mr. Randall,' since she could not accurately summarize it " $\mathrm{w}^{\text {th }}$ out danger of being mistaken." ${ }^{528}$ Knatchbull was also able to compromise when she judged it necessary, a task often difficult to accomplish in a situation of uneven power dynamics. When Hyde requested that she keep an account of all the letters going in and out of her epistolary network, Knatchbull resisted, writing that she could not obey his command because it would place too great a burden on her. ${ }^{529}$ Yet Knatchbull was careful not to refuse Hyde's request completely. Instead, she suggested compromise, that she would only keep track of Hyde's and the Secretary of State, Edward Nicholas's letters. ${ }^{530}$ In this way, Knatchbull demonstrates that she was not simply a passive recipient of Hyde's orders. While she was technically subservient to the men she corresponded with, she was still able to exercise a significant degree of independence and negotiation in their interactions.

\footnotetext{
${ }^{526}$ Walker, "Prayer, Patronage and Political Conspiracy," 10.

${ }^{527}$ Knatchbull to Hyde, 24 October 1658, Bodl., MS Clarendon 59, fol. 110.

${ }^{528}$ Knatchbull to Hyde, 24 October 1658, Bodl., MS Clarendon 59, fol. 110.

${ }^{529}$ She writes, "I...cannot possibly obey yo ${ }^{\mathrm{r}}$ command... it would be a greate wo $[r k]$ for me (who open all packetts my self and dispose of all lres)," Knatchbull to Hyde, 24 June 1659, Bodl., MS Clarendon 61, fol. 191.

${ }^{530}$ Knatchbull to Hyde, 24 June 1659, Bodl., MS Clarendon 61, fol. 191.
} 
The Royalist network within which Knatchbull operated was highly sophisticated. Correspondents regularly utilized ciphers and code names to transmit the most sensitive political information. ${ }^{531}$ In one instance, Knatchbull clarified the code names used in the Countess of Bristol's letters - the King was referred to as "Neece Browne" and Ormonde as "mrs Percivall." 532 As Caroline Bowden has argued, the use of female pseudonyms to represent powerful male figures suggests that these correspondents "were using current conceptions of the female gender role to their advantage." 533 This practice again testifies to the fact that, in this period, women, much less nuns, were not considered serious political threats. And yet, Mary Knatchbull placed significant emphasis on her desire to be of service to the royalist cause. ${ }^{534}$ At one point, in 1659 , Knatchbull's postal network appeared to catch the attention of English authorities. ${ }^{535}$ Knatchbull urged Hyde not to send any "dangerous" or political letters for a few posts until suspicion died down. ${ }^{536}$

\footnotetext{
${ }^{531}$ Walker, "Prayer, Patronage, and Political Conspiracy," 7.

${ }^{532}$ Knatchbull to Ormonde, 1659, Bodl., MS Carte 213, fol. 494.

${ }^{533}$ Bowden, "The Abbess and Mrs. Brown," 297.

${ }^{534}$ The significance placed on being 'of service' to the royal court in exile was also echoed by Mary Rose Howard. Howard once wrote to James, "my solitud would be doubly happy to heare that news [of your restoration], whilst I have long suffered life with impatience \& death in desire, yet my [sic] thinks this last news would compleate my desirs on earth." This transcription is quoted from Claire Walker, "The Experience of Exile in Early Modern English Convents," Parergon 34, no. 2 (2017): 176. The original letter can be found at Windsor, Royal Archives, Stuart Papers 90/127 (microfilm), Mary Rose Howard to James Frances Edward, 18 February 1726.

${ }^{535}$ Knatchbull to Hyde, 21 October 1659, Bodl., MS Clarendon 65, fol. 188. Knatchbull received word that her letters were suspected from a "frind" who transported her "packetts to and from England." However, Knatchbull was also able to judge for herself when her letters had been tampered with, once writing: "our English lres are come, but not to my sattisfaction in any kind, for either they have been opned and plundered by the way or somew ${ }^{t}$ very exerordinary is in wind," Knatchbull to [Hyde], 10 December 1659, Bodl., MS Clarendon 67, fol. 83.

536 "for two or 3 posts lett nothing be in my packetts $w^{\text {ch }}$ may not be seen," Knatchbull to Hyde, 21 October 1659, Bodl., MS Clarendon 65, fol. 188.
} 
Despite this, the abbess maintained that in the meantime she would "industristly contrive wayes for $\mathrm{yo}^{\mathrm{r}}$ service and tell you $\mathrm{w}^{\mathrm{n}}$ you may command againe." ${ }^{\circ 37}$

This suggests that Knatchbull knew that, without her letters and epistolary network, her value to the royalists was diminished. Rather than abandoning the cause, Knatchbull sought to restore her network and maintain her position of influence.

Despite her vocation as an enclosed nun who dedicated herself to religion, Knatchbull's letters reveal that she remained deeply involved in temporal and political affairs. However, one might understand Knatchbull's epistolary activity, and involvement in the secular world, as partially consistent with monastic life when we consider her letters as acts of spiritual service. The letters of Mary Caryll to her brother John, discussed in Chapter One, previously demonstrated that this type of exchange was common - Mary would pray for John's health and prosperity and he would assist her with convent business. Knatchbulls' correspondence reiterates that nun's letters were part of a larger 'spiritual economy' that traded epistolary prayers for material gain, be it funding, patronage, or other favours. For instance, Knatchbull once wrote to Ormonde, "I...can assure $\mathrm{yo}^{\mathrm{r}} \mathrm{Ex}^{\mathrm{cy}}$ wee redouble $\mathrm{o}^{\mathrm{r}}$ prayers for an increasing blessing and prosperity to all $\mathrm{yo}^{\mathrm{r}}$ affaires." ${ }^{, 538}$ Knatchbull's letters highlight how prayer acted a form of currency within reciprocal relationships. At the end of one letter, Knatchbull wrote:

"I must not omitt my owne greate conserne, the nescessityes of my community $\mathrm{w}^{\text {ch }}$ I most hartily commend to $\mathrm{yo}^{\mathrm{r}} \mathrm{Lo}^{\mathrm{tts}}$...charity, as occations shall administer you know $\mathrm{w}^{\mathrm{t}}$ it is to want a broad and therfore though wee may not come home to you will by yo ${ }^{\mathrm{r}}$ goodness and piety contrive some meanes by $\mathrm{w}^{\mathrm{ch}} \mathrm{w}^{\text {th }}$ more ease wee may abroad continue our prayers for you." 539

\footnotetext{
${ }^{537}$ Knatchbull to Hyde, 21 October 1659, Bodl., MS Clarendon 65, fol. 188.

${ }^{538}$ Knatchbull to Ormonde, 12 May 1660, Bodl., MS Carte 214, fol. 171.

${ }^{539}$ Knatchbull to [Hyde], 25 May 1660, Bodl., MS Clarendon 72, fol. 394. It is important to note that when this particular letter was written, Charles II was in the process of being restored as King
} 
In these lines, Knatchbull highlights the mutually beneficial nature of her relationship with Hyde. The abbess strategically links the easing of her convent's burden with her ability to continue to pray for him, and the royalist cause more broadly. In this way, Knatchbull offered one of the few resources she had (prayer) in order to strengthen the bonds between herself and her correspondents. ${ }^{540}$

There is an additional dimension that needs to be considered here, which is that Knatchbull was writing to men who did not share her religious identity as a Catholic. Hyde was notably a "staunch Anglican," Ormonde a Protestant, and while Charles II was sympathetic to Catholics, he was known for having a "chameleon-like attitude to religious toleration, which saw him support or stifle it according to political exigency." 541 Claire Walker has suggested that Knatchbull ultimately wanted to convert the king and other royalists, although this conclusion is based primarily on one letter the abbess wrote to Ormonde in $1686 .{ }^{542}$ While this letter does appear to have a clear proselytizing attempt, the same cannot be said for the letters she wrote in the 1650's and 1660's. This suggests that, at this time, Knatchbull's epistolary activity was motivated more by her political and financial ambitions than any missionary intent.

of England and the once exiled court, including Hyde, were returning to England. This left Knatchbull in a precarious situation since her epistolary network was no longer necessary. ${ }^{540}$ Claire Walker has stated that Mary Knatchbulls actions "generated such bonds of obligation and friendship that it was difficult for the king and his ministers to ignore completely her pleas for recompense" after the restoration, "Prayer, Patronage, and Political Conspiracy," 11. ${ }^{541}$ Walker, "Prayer, Patronage, and Political Conspiracy," 20-21; Barnard, "Butler, James, first duke of Ormond."

${ }^{542}$ In this letter Knatchbull wrote, "harden not yor hart against his holy Inspirations by any delay or difficulty," quoted in, Walker, "Doe not supose me a well mortifyed Nun dead to the world'," 173. 
Although most of Knatchbull's letters did not ask for favours outright, they can be understood within the larger context of letters as a form of social courtesy and networking. ${ }^{543}$ Knatchbull often used her letters to campaign for friends she judged useful to the royalist cause. In one letter, the abbess recommended three friends who she claimed to be men of "approved honesty," in the hopes that they would "experience the effects" of Hyde's "great goodness." ${ }^{444}$ Interestingly, two of these "friends" were her cousins, Francis and William Roper, which suggests that Knatchbull used her connections to benefit not only herself, but her family as well. ${ }^{545}$ As we have seen, Knatchbull's relationship with Hyde and Ormonde was based on reciprocity. The abbess provided a service and expected, explicitly or not, favours in return. In a letter to Ormonde, Knatchbull wrote, "I dare rank my self $\mathrm{w}^{\text {th }}$ the first that affectionatly pray for $\mathrm{yo}^{\mathrm{r}} \mathrm{Ex}^{\mathrm{cys}}$ prosperity, so I doe assure my self I am not the last for whom yo ${ }^{\mathrm{r}}$ bounty is conserned in the way of a generous care and kindness towards easing the burthen of our over opprest condission." ${ }^{546}$ Here, Knatchbull's emphasis on her convent's 'opprest condission' can be read as a strategic epistolary choice. As James Daybell has argued,

\footnotetext{
${ }^{543}$ James Daybell, "Gender, Politics and Diplomacy," 104. See also Daybell's article on petitionary letters - a form of correspondence where one requested favours from monarchs or other political figures, "Scripting a Female Voice: Women's Epistolary Rhetoric in SixteenthCentury Letters of Petition," Women's Writing 13, no. 1 (2006): 3-22.

${ }^{544}$ Knatchbull to [Hyde], 25 May 1660, Bodl., MS Clarendon 72, fol. 391.

${ }^{545}$ Knatchbull to [Hyde], 25 May 1660, Bodl., MS Clarendon 72, fol. 391. The third man was Charles Finch, it is unclear how he was connected to Knatchbull but this could indicate that other Royalists knew of Knatchbull's influence and utilized it accordingly. For more on this idea see Walker, "Prayer, Patronage, and Political Conspiracy," 15-16; Walker, Gender and Politics in Early Modern Europe, 113-114; Bowden, "The Abbess and Mrs. Brown," 303.

${ }^{546}$ Knatchbull to Ormonde, 9 September 1660, Bodl., MS Carte 31, fol. 28; Knatchbull used similar language in a letter to Hyde: "I must not omitt my most humnle thankes for all $\mathrm{yo}^{\mathrm{r}} \mathrm{Lo}^{\text {tts }}$ greate favours, $\mathrm{w}^{\text {ch }} \mathrm{I}$ assure $\mathrm{yo}^{\mathrm{r}} \mathrm{Lo}^{\text {tt }}$ have not been cast a way upon an ungratfull soule... I beseech $\mathrm{yo}^{\mathrm{r}} \mathrm{Lo}^{\mathrm{tt}}$ to understand me for $\mathrm{w}^{\mathrm{t}}$ is past and $\mathrm{w}^{\mathrm{t}}$ is to come as one whose aimes are swayed in all temporall things by his $\mathrm{Ma}^{\text {ltys }}$ interests and therfore by graunting $\mathrm{me}^{\mathrm{t}}$ you thinke fitt...you will allway graunt w ${ }^{t}$ I desire," Knatchbull to [Hyde], 25 May 1660, Bodl., MS Clarendon 72, fol. 391.
} 
emphasizing and exaggerating distress and desperation was an intentional strategy that women employed in their writing in order to obtain "the maximum amount of empathy for their situation." ${ }^{547}$ This is not to suggest that the Ghent convent was not suffering. However, it is necessary to question how Knatchbull may have framed the situation in order to motivate her correspondents to fulfill their promises - which is remarkably similar to how she utilized language earlier in her petitionary letter to the citizens of Ghent.

This is especially important since Knatchbull regularly extended her convent's financial resources to support the royalist cause. This included covering all the costs associated with the epistolary network and taking out multiple loans for Charles II and other royalists on her credit. ${ }^{548}$ Knatchbull used her letters to delicately put pressure on her correspondents, at one point writing to Ormonde, "pardon my presumption in still minding you of $\mathrm{yo}^{\mathrm{r}}$ owne promised and dearily desired favour." 549 Despite these epistolary pleas, the abbess was never fully repaid what she was owed. ${ }^{550}$ Nevertheless, as Laurence Lux-Sterritt has argued, Knatchbull took on these financial burdens because

\footnotetext{
${ }^{547}$ James Daybell, "Scripting a Female Voice," 12.

${ }^{548}$ Lux-Sterritt, English Benedictine Nuns in Exile in the Seventeenth Century, 126. At one point Knatchbull took on the debts of Ormonde's brother Richard, hoping that Ormonde would repay her. Knatchbull made numerous epistolary requests for these loans to be repaid and even sent nuns to England to meet with Charles II directly, Walker, "Prayer, Patronage, and Political Conspiracy," 6, 15-16; Walker, Gender and Politics in Early Modern Europe, 122, Bowden, "The Abbess and Mrs. Brown," 305.

${ }^{549}$ Knatchbull to Ormonde, 3 March 1660, Bodl., MS Carte 30, fol. 541. Another example of this can be seen when Knatchbull writes, "I pray God yo $^{\mathrm{r}} \mathrm{Lo}^{\text {tt }}$ may have been inabled to save my creditt for that day, otherwise I shall rather forfeit it $\mathrm{w}^{\text {th }}$ any hazard of my owne then putt $\mathrm{yo}^{\mathrm{r}} \mathrm{Lo}^{\mathrm{tt}}$ to such straits aboutt it as may inconvenience you. If $\mathrm{yo}^{\mathrm{r}} \mathrm{Lo}^{\text {tt }}$ can conveniently free me it will be a work of charity considering how farr the wants of my owne family preseth me to live on creditt, and you may please to pay it," Knatchbull to Hyde, 30 January 1659, Bodl., MS Clarendon 59, fol. 442 .

${ }^{550}$ Walker, "Prayer, Patronage, and Political Conspiracy," 16-17
} 
she viewed it as an "investment that would yield an incomparable return." ${ }^{51}$ Knatchbull, understood that connections fostered through letters were part of a larger strategy. In the short term, she gained influence and could petition for kin to receive favours, while in the long term, she hoped to position her convent to benefit financially, and even more optimistically, restore Catholicism in England.

Once Charles II was restored as King of England, the relationship between Mary Knatchbull and the royal court broke down significantly. ${ }^{552}$ This is due to the fact that, as Claire Walker has argued, "the abbess's influential position within the royalist camp, which had existed purely by virtue of her capacity to assist them, was lost." ${ }^{553}$ Charles II never followed through on his financial promises to Knatchbull, and under his reign the English convents on the continent remained in exile. ${ }^{554}$ After the restoration, Knatchbull largely withdrew from politics, limiting her contact with the royal family to the occasional polite letter. ${ }^{55}$ While Mary Knatchbull may not have achieved her larger objective of returning her convent to England, her correspondence reveals her success in becoming an 'invisible agent' and infiltrating traditionally male spheres of influence.

\footnotetext{
${ }^{551}$ Lux-Sterritt, English Benedictine Nuns in Exile in the Seventeenth Century, 126; Walker, " "Doe not supose me a well mortifyed Nun dead to the world'," 173.

${ }^{552}$ As Claire Walker has pointed out, "histories of the Restoration are unanimous in concluding that the king returned to England because of the breakdown of political authority after Cromwell's death, rather than through the efforts of the royalist conspirators," "Prayer, Patronage, and Political Conspiracy," 3.

${ }_{553}^{53}$ Walker, "Prayer, Patronage, and Political Conspiracy," 11.

${ }^{554}$ Caroline Bowden argues that although Charles II was listed as a principal benefactor of the Ghent convent, donating $£ 5,000$ and a $£ 500$ annuity, "a substantial proportion... has to be considered repayment of debt rather than donations," "The Abbess and Mrs. Brown," 291. Further, Charles II had promised Knatchbull $£ 2,000$ to found a new convent in Dunkrik but this was ultimately an empty promise, Walker, "Prayer, Patronage, and Political Conspiracy," 17. ${ }^{555}$ For example, in 1686 she wrote to Mary of Modena after she gave birth and in 1685 she wrote to James II after the death of his brother Charles II; Bowden, "The Abbess and Mrs. Brown," 306; Knatchbull to James II, March 3 1685, British Library, Letters to James II and Others with Cypher 1609-1688, Additional MS 21483, fol. 21.
} 
The authority that Knatchbull was able to gain through her correspondence in the $1650 \mathrm{~s}$ and $1660 \mathrm{~s}$ is telling. In that time, the abbess gained the respect and confidence of top political figures, earned the Ghent convent a prestigious reputation, and established two new convents. ${ }^{556}$ Knatchbull strategically utilized her epistolary network to gain influence and further the long-term survival of her convent. She tactically constructed her letters to appear submissive and downplay her abilities, while simultaneously proving her considerable skill and knowledge as a political agent. As a cloistered nun, letters were Knatchbull's only way to achieve her personal goals, whether that meant furthering her political ambitions for England or benefiting her convent directly. In either case, letters gave Mary Knatchbull an opportunity to exert power, but opportunity did not guarantee success.

\footnotetext{
${ }^{556}$ As Claire Walker has argued, "in spite of the failure of her political aims, Knatchbull remained a powerful figure within the English Catholic community by virtue of her association with the monarch. During the 1660 s through to the 1680 s, her cloisters flourished, attracting many new postulants," and she founded two new convents, one at Dunkirk in 1662 and Ypres in 1665. Walker, "Prayer, Patronage and Political Conspiracy," 19; Walker, "Loyal and Dutiful Subjects," 238; Walker, Gender and Politics in Early Modern Europe, 17.
} 


\section{Conclusion}

One purpose behind studying women's epistolary communication, as James Daybell and Andrew Gordon have argued, is to understand "the complex ways in which the female subject lived in and through the instrument of the letter." 557 This thesis has attempted to trace how early modern English nuns did just that. Rather than straightforwardly considering letters as uncomplicated pieces of historical evidence, we have seen that letters were a dynamic tool, wielded to achieve specific purposes. Letters were much more than words on paper. They were the only medium that allowed nuns the opportunity to engage, strategically and enthusiastically, with the outside world, to secure the economic stability of their convent, and - from their point of view - to preserve the English Catholic faith. Letters allowed convents not only to survive, but thrive, as nuns created and maintained patronage networks that provided financial security, delivered spiritual relief to recusant Catholics, engaged with the public political sphere, and defend their spiritual direction.

Nuns themselves recognized the power of letters. As Gabriella Zarri has argued with respect to continental convents, letter writing took on an increasingly powerful role after the monastic reforms of the Council of Trent. ${ }^{558}$ Within English convents, despite enclosure, letters allowed nuns to remain connected to the outside world. Through letters, nuns such as Winefrid Thimelby, Mary Caryll and the Hagan sisters were able to maintain deep emotional connections to their natal families. Without letters, Thimelby

\footnotetext{
${ }^{557}$ James Daybell and Andrew Gordon, "Living Letters: Re-Reading Correspondence and Women's Letters," in Women and Epistolary Agency in Early Modern Culture, 1450-1690, ed. by J. Daybell and A. Gordon (London: Routledge, 2016), 1.

${ }^{558}$ Gabriella Zarri "Sixteenth Century Letters: Typologies and Examples From the Monastic Circuits," in Reading, Interpreting and Historicizing: Letters as Historical Sources, ed. by Regina Schlute and Xenia Von Tippelskirch (Florence: European University Institute, 2004), 44.
} 
would have struggled to recruit her niece Katherine, Caryll would not have been able to use her brother's connections and resources to benefit her convent, and the bond between the Hagan sisters would have been broken. Had they not reached out to supporters through letters, Christina Brent and Catherine Gascoigne would have had little other recourse to defend and preserve their spiritual books from Claude White. Letters also provided the Brussels nuns with an outlet to express diverse views on their spiritual direction and on the behaviour of sister nuns. And while Mary Knatchbull may have always held strong political views and ambitious goals for her convent, letters gave her an opportunity to enter otherwise inaccessible spheres of influence. In other words, none of these women religious would have achieved her objectives had it not been for the letter.

One of the main motivations for epistolary activity was economic security. Letters were fundamental for preserving the networks that supported familial recruitment and thus ensured the financial security of convents. English convents relied on the dowries (or portions) of new recruits and donations from benefactors to remain financially stable. ${ }^{559}$ And convent recruitment patterns show that familial bonds were maintained within the cloister. ${ }^{560}$ Thimelby, Knatchbull, the Caryll family and the Hagan sisters (to name a few) all had relatives join religious orders. Letters also allowed the exploits and achievements (positive or negative) of convents to spread to potential recruits and benefactors. Letter

\footnotetext{
${ }^{559}$ Caroline Bowden, "Patronage and Practice: Assessing the Significance of the English Convents as Cultural Centres in Flanders in the Seventeenth Century," English Studies 92, no. 5 (2011): 487.

${ }^{560}$ Lux-Sterritt, English Benedictine Nuns in Exile in the Seventeenth: Living Spirituality (Manchester: Manchester University Press, 2017), 60-61; Claire Walker, Gender and Politics in Early Modern Europe: English Convents in France and the Low Countries (New York: Palgrave Macmillan, 2003), 27-30.
} 
writing was therefore essential for practical reasons, helping guarantee spiritual prosperity.

Letters also facilitated a spiritual economy. As we saw, the Benedictine statute stipulated that letters only be sent, so that outsiders may receive "spirituall proffitt from them. ${ }^{561}$ Nuns, such as Mary Caryll and Mary Knatchbull strategically exploited this rule to create a quid-pro-quo system that benefited both them and their correspondents. While Mary Knatchbull's involvement in politics may be more overt than Mary Caryll's, comparison allows us to see that their letters functioned on a spectrum of spiritual service. Mary Knatchbull resorted to external networks of influential male figures to gain power for her convent. Although Knatchbull corresponded with men who did not share her Catholic faith, she was still able to utilize prayer as an effective form of reciprocity in exchange for material favours. Alternatively, Mary Caryll focused on the connections of her natal family, specifically her brother John, which she used to her convent's advantage. Mary provided John with spiritual edification. In return, he both supported his sister financially and facilitated a relationship between the convent and royal court. These acts of spiritual reciprocity were central to convents, and letters allowed these exchanges to be more frequent and ritualized. This connects to the idea that English convents represented the survival and preservation of English Catholicism. Exile on the continent was perceived as a temporary state. Letters allowed women religious not simply to preserve the Catholic faith among recusants, but to strengthen it through epistolary spiritual labour.

\footnotetext{
${ }^{561}$ Brussels Benedictine Statutes, The First Parte, 38.
} 
Whether to secure financial stability, recruit new members, ensure spiritual security, or gain influence and authority, nuns knew that letters had to be carefully constructed. As we have seen, nuns made a series of epistolary choices. Many women religious utilized gender norms to their advantage. For example, the use of deferential language was common. This allowed nuns to present themselves as submissive and obedient, while concealing their bold and authoritative presence. Nuns had to be strategic in their tone and in the information they conveyed to their allies. In fact, sympathy and exaggeration were both frequently used epistolary tools. For instance, Mary Knatchbull, Christina Brent, Catherine Gascoigne and multiple nuns from Brussels applied this strategy in their letters in order to convince their correspondents of the seriousness and urgency of their particular circumstances. Others, such as Arabella Benedicta Caryll, were not averse to using a sterner tone when humility, flattery and sympathy did not achieve the desired results. Letters were not neutral documents, but were carefully and intentionally composed.

By the end of the eighteenth century, the continent experienced heightened religious tension and was no longer the safe haven it had once been for English nuns. ${ }^{562}$ Back in England, however, the situation was improving. Catholic worship was legalized by the Relief Act of 1791, which made migration back home possible for nuns and recusant Catholics. ${ }^{563}$ In the end, some English convents, such as the Paris Augustinians,

\footnotetext{
${ }^{562}$ For more on the end of English convents in exile see Caroline Bowden, "General Introduction," in English Convents in Exile, 1600-1800: Volume 1. History Writing, xxv-xxvi; Carmen Mangion, "Avoiding 'Rash and Imprudent Measures': English Nuns in Revolutionary Paris, 1789-1801," in The English Convents in Exile, 1600-1800, ed. by Caroline Bowden and James E. Kelly (Burlington, VT: Ashgate, 2013): 247-263.

${ }^{563}$ Bowden, "General Introduction," xxv.
} 
chose to remain in exile, while many others returned to England. ${ }^{564}$ Regardless of their fate, it is clear that the English convents in exile left a significant mark on the history of English Catholicism. This thesis has argued that the success of English convents would not have been possible without the mechanism of the letter. With injunctions to separate themselves from the world, nuns utilized letters to ensure their convents' survival. As we have seen, letters were not always successful: some debts remained unpaid and news of internal conflict often harmed reputations. Nonetheless, letters afforded women religious a precious opportunity - what they did with it, well, that was up to them.

\footnotetext{
${ }^{564}$ As Bowden argues, the decision to return to England was not without hardships, and many women religious lost their possessions, documents and even their lives making the journey; "General Introduction," xxvi. For a list of convents and their fate at the end of the exile period see "General Introduction," xxix-xxxiii.
} 


\section{Bibliography}

\section{Primary Sources}

\section{Archival Material}

\section{Archief van het Aartsbisdom Mechelen (AAM), Mechelen, Belgium}

Conventualia, Engelse Benedictinessen, Brussel box 12/1, unfoliated.

Conventualia, Engelse Benedictinessen, Brussel box 12/2, unfoliated.

Conventualia, Engelse Benedictinessen, Brussel box 12/3, unfoliated.

\section{British Library (BL), London}

Aston Papers Vol. IX, BL Additional MS 36452.

Family of Caryll Correspondence, Vol. I, 1672-1718, Additional MS 28227.

Family of Caryll Correspondence, Vol. II, 1719-1731, Additional MS 28228.

Family of Caryll Correspondence, Vol. III, 1732-1739, Additional MS 28229.

Family of Caryll Correspondence, Vol. V. 1748-1755, Additional MS 28231.

Family of Caryll Correspondence, Vol. VI, 1756-1758, Additional MS 28232.

Letters and Papers of John Caryll, 1648-1711, Additional MS 28226.

Letters to James II and Others with Cypher 1609-1688, BL Additional MS 21483.

Nicholas Papers, Egerton MS 2536.

\section{Bodleian Library (Bodl.), Oxford}

Thurloe's Papers Vol. XXXVI, March 1656, Rawlinson MS A.36.

Carte Papers, 1604-1660, MS Carte 30.

Carte Papers, 1660-1662, MS Carte 31.

Carte Papers, Letters 1650-1660, MS Carte 213.

Carte Papers, Letters 1660-1663, MS Carte 214. 
Clarendon State Papers, June-Oct. 1656, MS Clarendon 52.

Clarendon State Papers, Jan.-Apr. 1658, MS Clarendon 57.

Clarendon State Papers, Oct. 1658 to Jan. 1659, MS Clarendon 59.

Clarendon State Papers, June-July 1659, MS Clarendon 61.

Clarendon State Papers, July 18-July 31 1659, MS Clarendon 62.

Clarendon State Papers, Sept. 1659, MS Clarendon 64.

Clarendon State Papers, Nov. 1659, MS Clarendon 66.

Clarendon State Papers, MS Clarendon 67.

Clarendon State Papers, April 1660, MS Clarendon 71.

Clarendon State Papers, May 1660, MS Clarendon 72.

\section{National Archives, Kew}

State Papers, $77 / 32$

\section{Oulton Abbey Archives (OA), Stafford}

Appeal to the Citizens of Ghent: 'An account of the necessitys of the community,' MS G.11.

\section{Printed Primary Sources}

"Connections Between Europe and America Before Independence." In English Convents in Exile, 1600-1800: Volume 6: The Convents and the Outside World, edited by Carmen M. Mangion, Michael Questier, Emma Major and Caroline Bowden, 143-153. London: Pickering \& Chatto, 2012.

"Convent Controversy and Intercepted Letters from Cambrai and Paris: 'We are now brought into most narrow straites'." In English Convents in Exile, 1600-1800: Volume 3. Life Writing, edited by Nicky Hallett, Elizabeth Perry and Victoria van Hyning, 285-294. London: Pickering \& Chatto, 2012.

"Letter of Mary Louisa Hagan." In English Convents in Exile, 1600-1800: Volume 6. The Convents and the Outside World, edited by Carmen M. Mangion Michael Questier, Emma Major and Caroline Bowden, 279-282. London: Pickering \& Chatto, 2012. 
"Letters to and From Bruges, Lisbon and Paris: Correspondence of the Huddleston Family." In English Convents in Exile, 1600-1800: Volume 3. Life Writing I, edited by Nicky Hallett, Elizabeth Perry and Victoria van Hyning, 295-306. London: Pickering \& Chatto, 2012.

"Poor Clares of Aire: Correspondence of the Conyers Family." In English Convents in Exile, 1600-1800: Volume 3. Life Writing I, edited by Nicky Hallett, Elizabeth Perry and Victoria van Hyning, 273-285. London: Pickering \& Chatto, 2012.

"Poor Clares of Aire: Correspondence of the Conyers Family." In English Convents in Exile, 1600-1800: Volume 6: The Convents and the Outside World, edited by Carmen M. Mangion, Michael Questier, Emma Major and Caroline Bowden, 383-389. London: Pickering \& Chatto, 2012.

Statutes Compyled for the Better Observation of the Holy Rule of the Most Glorious Father and Patriarch S. Benedict. Ghent, 1632.

"Thimelby-Aston Literary Exchanges: 'Itt imports not wher but how we live'." In English Convents in Exile, 1600-1800: Volume 3. Life Writing I, edited by Nicky Hallett, Elizabeth Perry and Victoria van Hyning, 263-272. London: Pickering \& Chatto, 2012.

Tixall Letters; or the Correspondence of The Aston Family and their Friends during the seventeenth century, vol. 2, edited by Arthur Clifford. Edinburgh: James Ballantyne \& Co., 1815.

\section{Online Material}

Who were the Nuns? Database. Supported by Queen Mary, University of London (2012). http://wwtn.history.qmul.ac.uk/index.html.

\section{Secondary Sources}

Akkerman, Nadine. Invisible Agents: Women and Espionage in Seventeenth-Century Britain. Oxford: Oxford University Press, 2018.

Allison, Antony F. "The English Augustinian Convent of our Lady of Syon at Paris: Its Foundation and Struggle for Survival during the First Eighty Years, 1634 1713." Recusant History 21, no. 4 (1993): 451-496.

Avishai, Orit, Lynne Gerber, and Jennifer Randles. “The Feminist Ethnographer's Dilemma: Reconciling Progressive Research Agendas with Fieldwork Realities.” Journal of Contemporary Ethnography 42, no. 4 (2013): 394-426.

Barnard Toby. "Butler, James, first duke of Ormond.” Oxford Dictionary of National Biography. 04 Oct. 2008. https://doi.org/10.1093/ref:odnb/4191 
Bernard, G. W. The King's Reformation: Henry VIII and the Remaking of the English Church. New Haven: Yale University Press, 2005.

“The Dissolution of the Monasteries.” History 96, no. 4 (2011): 390-409.

Blud, Victoria. "Beyond the Sea: Medieval Mystic Space and Early Modern Convents in Exile." In Gender in Medieval Places, Spaces and Thresholds, edited by Victoria Blud, Diane Heath, and Einat Klafter, 75-90. London: University of London Press, 2019.

Bossy, John. The English Catholic Community, 1570-1850. London: Darton, Longman and Todd, 1975.

Bowden, Caroline. "The Abbess and Mrs. Brown: Lady Mary Knatchbull and Royalist Politics in Flanders in the Late 1650s." Recusant History, 24 (1999): 288-308.

"'For the Glory of God': A Study of the Education of English Catholic Women in Convents in Flanders and France in the First Half of the Seventeenth Century." Paedagogica Historica 35 (1999): 77-95.

"The Role of Mary Knatchbull in the English Benedictine Foundations of the Seventeenth Century." Magistra 8, no. 1 (2002): 26-52.

"Knatchbull, Mary (1610-1696), Abbess of the Convent of the Immaculate Conception, Ghent." Oxford Dictionary of National Biography. 23 Sep. 2004. https://doi.org/10.1093/ref:odnb/66452

"Community Space and Cultural Transmission: Formation and Schooling in English Enclosed Convents in the Seventeenth Century." History of Education 34, no. 4 (2005): 365-386.

"Collecting the Lives of Early Modern Women Religious: Obituary Writing and the Development of Collective Memory and Corporate Identity." Women's History Review 19, no. 1 (2010): 7-20.

"The English Convents in Exile and Questions of National Identity c.16001688." In British and Irish Emigrants and Exiles in Europe, 1603-1688, edited by David Worthington, 297-314. Leiden: Brill, 2010.

"Patronage and Practice: Assessing the Significance of the English Convents as Cultural Centres in Flanders in the Seventeenth Century." English Studies 92, no. 5 (2011): 483-495.

“General Introduction." In English Convents in Exile, 1600-1800: Volume 1. History Writing, edited by Caroline Bowden, xi-xxxiv. London: Pickering \& Chatto, 2012. 
"Introduction: History Writing in the English Convents." In English Convents in Exile, 1600-1800: Volume 1. History Writing, edited by Caroline Bowden, xxxixxlv. London: Pickering \& Chatto, 2012.

"Missing Members: Selection and Governance in the English Convents in Exile." In The English Convents in Exile, 1600-1800, edited by Caroline Bowden and James E. Kelly, 53-68. Burlington, VT: Ashgate, 2013.

"Building Libraries in Exile: The English Convents and Their Book Collections in the Seventeenth Century." British Catholic History 32, no. 3 (2015), 343-382.

Bowden Caroline, James E. Kelly, and Michael C. Questier. "Introduction." In The English Convents in Exile, 1600-1800, edited by Caroline Bowden and James E. Kelly, 1-16. Burlington, VT: Ashgate, 2013.

Broomhall, Susan and Jacqueline Van Gent. "Corresponding Affections: Emotional Exchange among Siblings in the Nassau Family." Journal of Family History 34, no. 2 (2009): 143-165.

"Letters Make the Family: Nassau Family Correspondence at the Turn of the Seventeenth Century." In Early Modern Women and Transnational Communities of Letters, edited by Julie D. Campbell and Anne R. Larson, 25-44. Burlington, VT: Ashgate, 2009.

Bynum, Caroline Walker. Holy Feast and Holy Fast: The Religious Significance of Food to Medieval Women. Berkeley: University of California Press, 1987.

Fragmentation and Redemption: Essays on Gender and the Human Body in Medieval Religion. New York: Zone Books, 1991.

Metamorphosis and Identity. New York: Zone Books, 2001.

Camiciotti, Gabriella Del Lungo. "Letters and Letter Writing in Early Modern Culture: An Introduction." Journal of Early Modern Studies 3, no. 3 (2014): 17-35.

Campbell, Julie D. and Anne R. Larson, "Introduction.” In Early Modern Women and Transnational Communities of Letters, edited by Julie D. Campbell and Anne R. Larson, 1-21. Burlington, VT: Ashgate, 2009.

Capp, Bernard. The Ties that Bind: Siblings, Family, and Society in Early Modern England. Oxford: Oxford University Press, 2018.

Clark, Elizabeth A. "Women, Gender, and the Study of Christian History." Church History 70, no. 3 (2001): 395-426. 
Collinson, Patrick. "Elizabeth I (1533-1603), Queen of England and Ireland." Oxford Dictionary of National Biography. 23 Sep. 2004.

https://doi.org/10.1093/ref:odnb/8636

Coolahan, Marie Louise. “Identity Politics and Nuns' Writing." Women's Writing 14.2 (2007): 306-320.

Corens, Liesbeth. "Catholic Nuns and English Identities. English Protestant Travellers on the English Convents in the Low Countries, 1660-1730." Recusant History 30, no. 3 (2011): 441-459.

"Saints Beyond Borders: Relics and the Expatriate English Catholic Community." In Exile and the Formation of Religious Identities in the Early Modern World, edited by Jesse Spohnholz and Gary Waite, 25-38. London: Pickering \& Chatto, 2014.

Couchman, Jane. "Resisting Henry IV: Catherine de Bourbon and her brother." In Sibling Relations and Gender in the Early Modern World: Sisters, Brothers and Others, edited by Naomi J Miller and Naomi Yavneh, 64-76. Aldershot: Ashgate, 2006.

Crawford, Patricia. Women and Religion in England, 1500-1720. New York: Routledge, 1993.

Currier, Charles Warren. Carmel in America: A Centennial History of the Discalced Carmelites in the United States. Baltimore: J. Murphy \& co, 1890.

Davis, Natalie Zemon. "“Women's History' in Transition: The European Case." Feminist Studies 3, no. 3/4 (1976): 83-103

Women on the Margins: Three Seventeenth-Century Lives. Cambridge, MA.: Harvard University Press, 1995.

Daybell, James. "Introduction.” In Early Modern Women's Letter-Writing, 1450-1700, edited by J. Daybell, 1-15. Basingstoke: Palgrave Macmillan, 2001.

“'Scripting a Female Voice: Women's Epistolary Rhetoric in Sixteenth-Century Letters of Petition." Women's Writing 13, no. 1 (2006): 3-22.

"Material Meanings and the Social Signs of Manuscript Letters in Early Modern England." Literature Compass 6, no. 3 (2009): 647-667.

"Gender, Obedience, and Authority in Sixteenth-Century Women's Letters." The Sixteenth Century Journal 41, no. 1 (2010): 49-67. 
"Gender, Politics and Diplomacy: Women, News and Intelligence Networks in Elizabethan England." In Diplomacy and Early Modern Culture, edited by Robyn Adams and Rosanna Cox, 101-119. London: Palgrave Macmillan, 2011.

- The Material Letter in Early Modern England: Manuscript Letters and the Culture and Practices of Letter-Writing, 1512-1635. New York: Palgrave Macmillan, 2012.

Daybell, James and Andrew Gordon. "Living Letters: Re-Reading Correspondence and Women's Letters." In Women and Epistolary Agency in Early Modern Culture, 1450-1690, edited by James Daybell and Andrew Gordon, 1-19. London: Routledge, 2016.

Devries, Jacqueline. "Rediscovering Christianity After the Postmodern Turn." History Compass 4, no. 4 (2006): 135-155.

Dickens, Arthur G., and Dorothy Carr. The Reformation in England: To the Accesssion of Elizabeth I. London: Edward Arnold, 1967.

Dickens, Arthur G. The English Reformation. London: Collins, 1964.

Diefendorf, Barbara B. From Penitence to Charity: Pious Women and the Catholic Reformation in Paris. Oxford: Oxford University Press, 2004.

Dolan Frances E. Whores of Babylon: Catholicism, Gender, and Seventeenth-Century Print Culture. Cornell: Cornell University Press, 1999.

Erskine-Hill, Howard. "Caryll, John, Jacobite first Baron Caryll of Durford.” Oxford Dictionary of National Biography. 23 Sep. 2004.

https://doi.org/10.1093/ref:odnb/4847

" "Caryll, John, Jacobite second Baron Caryll of Durford." Oxford Dictionary of National Biography. 23 Sep. 2004. https://doi.org/10.1093/ref:odnb/4848

Evengelisti, Silvia. Nuns: A History of Convent Life 1450-1700. Oxford: Oxford University Press, 2007.

Ezell, Margaret J. M. Writing Women's Literary History. Baltimore: Johns Hopkins University Press, 1993.

Franklin, Caroline. "Introduction: The Material Culture of Eighteenth-Century Women's Writing." Women's Writing 21, no. 3 (2014): 285-289.

Gertz, Genelle. "Barbara Constable's Advice for Confessors and the Tradition of Medieval Holy Women." In The English Convents in Exile, 1600-1800, edited by Caroline Bowden and James E. Kelly, 123-138. Burlington, VT: Ashgate, 2013. 
Gevirtz, Karen. "Recent Developments in 17th and 18th-Century English Catholic Studies: Studies in English Catholicism.” Literature Compass 12, no. 2 (2015): 47-58.

Gilchrist, Roberta. Gender and Material Culture: The Archaeology of Religious Women. New York: Routledge, 1994.

Gluckman, Max. “Gossip and Scandal.” Current Anthropology 4, no.3 (1963): 307-316.

Goldsmith, Elizabeth C. "Authority, Authenticity, and the Publication of Letters by Women.” In Writing the Female Voice: Essays on Epistolary Literature, edited by Elizabeth C. Goldsmith, 46-59. London: Pinter, 1989.

“Introduction." In Writing the Female Voice: Essays on Epistolary Literature, edited by Elizabeth C. Goldsmith, vii-xiii. London: Pinter, 1989.

Goodrich, Jaime. Faithful Translators: Authorship, Gender and Religion in Early Modern England. Evanston, Illinois: Northwestern University Press, 2013.

"Translating Lady Mary Percy: Authorship and Authority among the Brussels Benedictines." In The English Convents in Exile, 1600-1800: Communities, Culture and Identity, edited by Caroline Bowden and James E. Kelly, 109-22. Burlington, VT: Ashgate, 2013.

"Nuns and Community-Centered Writing: The Benedictine Rule and Brussels Statutes.” Huntington Library Quarterly 77, no. 3 (2014): 287-303.

"Authority, Gender, and Monastic Piety: Controversies at the English Benedictine Convent in Brussels, 1620-1623.” British Catholic History 33, no. 1 (2016): 91-114.

Gottemoeller, Doris. "Religious Life for Women: From Enclosure to Immersion." In From Trent to Vatican II: Historical and Theological Investigations, edited by Raymond Bulman and Frederick Parella, 228-240. Oxford: Oxford University Press, 2006.

Gregg, Edward. "James Francis Edward [James Francis Edward Stuart; styled James; known as Chevalier de St George, the Pretender, the Old Pretender] (1688-1766), Jacobite claimant to the thrones of England, Scotland, and Ireland." Oxford Dictionary of National Biography. 24 May. 2012. https://doi.org/10.1093/ref:odnb/14594

Gregory, Brad S. "Situating Early Modern English Catholicism." In Early Modern English Catholicism, edited by James Kelly and Susan Royal, 17-40. Boston: Routledge, 2017. 
Grundy, Isobel. "Women's history? Writings by English Nuns." In Women, Writing, History, 1640-1740, edited by Isobel Grundy and Susan Wiseman, 126-138. London: B.T. Batsford, 1992.

Guilday, Peter. The English Catholic Refugees on the Continent 1558-1795. London: Longmans, 1914.

Hackett, Helen. "Women and Catholic Manuscript Networks in Seventeenth-Century England: New Research on Constance Aston Fowler's Miscellany of Sacred and Secular Verse.” Renaissance Quarterly 65, no. 4 (2012): 1094-1124.

Hallett, Nicky. Lives of Spirit: English Carmelite Self-Writing of the Early Modern Period. Aldershot: Ashgate, 2007.

"Paradise Postponed: The Nationhood of Nuns in the 1670s." In Religion, Culture and the National Community in the 1670s, edited by T. Claydon and T. Corns, 10-34. Cardiff: University of Wales Press, 2011.

"Introduction: The Life Writing of Early Modern Nuns." In English Convents in Exile, 1600-1800: Volume 3. Life Writing I. General Editor Caroline Bowden, edited by Nicky Hallett, contributing editors Elizabeth Perry and Victoria van Hyning, xi-xxiv. London: Pickering \& Chatto, 2012.

Hannan, Leonie. Women of Letters: Gender, Writing and the Life of the Mind in Early Modern England. Manchester: Manchester University Press, 2016.

Harding, Sandra. "Introduction: Is There a Feminist Method?" In Feminism \& Methodology, edited by Sandra Harding, 1-14. Bloomington: Indiana University Press, 1987.

Harline, Craig. "Actives and Contemplatives: the female religious of the Low Countries before and after Trent." Catholic Historical Review 81, no. 4 (1995): 541-67.

Hills, Helen. Invisible City: The Architecture of Devotion in Seventeenth Century Neapolitan Convents. New York: Oxford University Press, 2004.

Hollinshead, Janet E. Women of the Catholic Community: The Blundells of South Lancashire during the Seventeenth and Eighteenth Centuries. Lancashire: North West Catholic History Society, 2010.

How, James. Epistolary Spaces: English Letter Writing from the Foundation of the Post Office to Richardson's Clarissa. Aldershot: Ashgate, 2003.

Ives, Eric W. "Henry VIII (1491-1547), King of England and Ireland." Oxford Dictionary of National Biography. 23 Sep. 2004. https://doi.org/10.1093/ref:odnb/12955 
The Reformation Experience: Living Through the Turbulent 16th Century. Oxford: Lion, 2012.

Kelly, James E. "Jesuit News Networks and Catholic Identity: The Letters of John Thorpe to the English Carmelite Nuns at Lierre, 1769-89." In Jesuit Intellectual and Physical Exchange Between England and Mainland Europe, c.1580-1789, edited by James E. Kelly and Hannah Thomas, 337-360. Leiden: Brill, 2018.

English Convents in Catholic Europe, c.1600-1800. Cambridge: Cambridge University Press, 2020.

Kelly-Gadol, Joan. "The Social Relation of the Sexes: Methodological Implications of Women's History." In Feminism and Methodology, edited by Sandra Harding, 15-28. Bloomington: Indiana University Press, 1987

"Did Women Have a Renaissance?" In Becoming Visible: Women in European History, edited by Claudia Koonz and Renate Bridenthal, 137-164. Boston: Mifflin, 1977.

Women, History \& Theory: The Essays of Joan Kelly. Chicago: University of Chicago Press, 1984.

Knowles David. Bare Ruined Choirs: The Dissolution of the English Monasteries. Cambridge: Cambridge University Press, 1976.

Küng, Hans The Catholic Church. New York: The Modern Library, 2003.

Larminie, Vivienne. "Fighting for Family in a Patronage Society: the Epistolary Armoury of Anne Newdigate (1574-1618)." In Early Modern Women's LetterWriting, 1450-1700, edited by James Daybell, 159-176. Basingstoke: Palgrave Macmillan, 2001.

Laven, Mary. Virgins of Venice: Enclosed Lives and Broken Vows in the Renaissance Convent. London: Viking Penguin, 2002.

Lay, Jenna. “An English Nun's Authority: Early Modern Spiritual Controversy and the Manuscripts of Barbara Constable." In Gender, Catholicism and Spirituality: Women and the Roman Catholic Church in Britain and Europe, 1200-1900, edited by Laurence Lux-Sterrit and Carmen M. Mangion, 99-114. Basingstoke: Palgrave Macmillan, 2011.

“The Literary Lives of Nuns: Crafting Identity Through Exile." In The English Convents in Exile, 1600-1800, edited by Caroline Bowden and James E. Kelly, 71-86. Burlington, VT: Ashgate, 2013. 
Lehfeldt, Elizabeth A. "The Permeable Cloister." In The Ashgate Companion to Women and Gender in Early Modern Europe edited by Jane Couchman, Allyson M. Poska, and Katherine A. McIver, 13-31. Abingdon: Routledge, 2013.

Lux-Sterritt, Laurence. English Benedictine Nuns in Exile in the Seventeenth Century: Living Spirituality. Manchester: Manchester University Press, 2017.

"Between the Cloister and the World: The Successful Compromise of the Ursulines of Toulouse, 1604-1616.” French History 16, no.3 (2002): 247-268.

Lux-Sterritt, Laurence and Carmen M. Mangion, Gender, Catholicism and Spirituality: Women and the Roman Catholic Church in Britain and Europe, 12001900. Basingstoke: Palgrave Macmillan, 2011.

Mangion, Carmen. "Introduction." In The English Convents in Exile, 1600-1800: Volume 6. The Convents in the Outside World. General Editor Caroline Bowden, edited by Carmen M. Mangion, contributing editors Michael Questier, and Emma Major, xv-xvii. London: Pickering \& Chatto, 2012.

"Avoiding 'Rash and Imprudent Measures': English Nuns in Revolutionary Paris, 1789-1801." In The English Convents in Exile, 1600-1800, edited by Caroline Bowden and James E. Kelly, 247-263. Burlington, VT: Ashgate, 2013.

McNamara, Jo Ann. Sisters in Arms: Catholic Nuns through Two Millennia. Cambridge, MA: Harvard University Press, 1996.

McShane, Bronagh Ann. "Visualising the Reception and Circulation of Early Modern Nuns' Letters.” Journal of Historical Network Research 2 (2018): 1-25.

"Negotiating Religious Change and Conflict: Female Religious Communities in Early Modern Ireland, c.1530-c.1641." British Catholic History 33, no. 3 (2017): 357-382.

Medioli, Francesca. "An Unequal Law: The Enforcement of Clausura Before and After the Council of Trent." In Women in Renaissance and Early Modern Europe, edited by Christine E. Meek, 136-52. Dublin: Four Courts Press, 2000.

Mendelson, Sara Heller and Patricia Crawford. Women in Early Modern England, 15501720. Oxford and New York: Clarendon Press, 1998.

Merry, Sally Engle. "Rethinking Gossip and Scandal." In Toward a General Theory of Social Control, edited by Donald J. Black, 271-302. London: Academic Press, 1984. 
Miller, Naomi J and Naomi Yavneh. "Introduction: Thicker Than Water." In Sibling Relations and Gender in the Early Modern World: Sisters, Brothers and Others, edited by Naomi J. Miller and Naomi Yavneh, 1-14. Aldershot: Ashgate, 2006.

Monson, Craig A. "Families, Convents, Music: The Power of Sisterhood." In Sibling Relations and Gender in the Early Modern World: Sisters, Brothers and Others, edited by Naomi J. Miller and Naomi Yavneh, 40-52. Aldershot: Ashgate, 2006

Morgan, Sue. "Introduction. Women, Religion and Feminism: Past Present and Future Perspectives," in Women, Religion, and Feminism in Britain, 1750-1900, edited by S. Morgan, 1-19. Basingstoke: Palgrave Macmillan, 2002.

Murphy, Emilie K. "Language and Power in an English Convent in Exile, c. 1621-c. 1631." Historical Journal 62, no. 1 (2019): 1-25.

O'Malley, John W. Trent: What Happened at the Council. Cambridge, MA: Harvard University Press, 2013.

O'Neill, Lindsay. The Opened Letter: Networking in the Early Modern British World. Philadelphia: University of Pennsylvania Press, 2014.

Pacheco, Anita. "Introduction." In A Companion to Early Modern Women's Writing, edited. by A. Pacheco, xiv-xx. Oxford: Blackwell, 2002.

Pando-Canteli, María Jesús. “Expatriates. Women’s Communities, Mobility and Cosmopolitanism in Early Modern Europe: English and Spanish Nuns in Flanders." In Women Telling Nations, volume 1, edited by Amelia Sanz, Francesca Scott and Suzan van Dijk, 85-101. Leiden: Brill/Rodopi, 2014.

Petkov, Kiril. The Kiss of Peace Ritual, Self, and Society in the High and Late Medieval West. Leiden: Brill, 2003.

Pfannebecker, Mareile. "'Love's Interest': Agency and Identity in a Seventeenth-Century Nun's Letters." Literature Compass 3, no. 2 (2006): 149-158.

Pollock, Linda A. "Rethinking Patriarchy and the Family in Seventeenth-Century England." Journal of Family History 23, no. 1 (1998): 3-27.

Power, Eileen. Medieval English Nunneries, c. 1275 to 1535. New York: Biblo and Tannen, 1964.

Randall, David. Credibility in Elizabethan and Early Stuart Military News. London: Pickering \& Chatto, 2008.

Rapley, Elizabeth. The Dévotes: Women and Church in Seventeenth-Century France. Montreal: McGill-Queen's University Press, 1990. 
Raymond, Joad and Noah Moxham. "News Networks in Early Modern Europe." In News Networks in Early Modern Europe, edited by Noah Moxham and Joad Raymond, 1-16. Leiden: Brill, 2016.

Rubin, Miri. Mother of God: A History of the Virgin Mary. London: Allen Lane, 2009.

Sanders, Julie C. "Tixall Revisited: The Coterie Writings of the Astons and Thimelbys in Seventeenth-Century Staffordshire." In Women Writing 1550-1750, edited by J. Wallwork and P. Salzman, 47-57. Bundoora: La Trobe University, 2001.

Schneider, Gary. "Affecting Correspondences: Body, Behavior, and the Textualization of Emotion in Early Modern English Letters." Prose Studies 23, no. 3 (2000): 31-62.

Schobesberger, Nikolaus, Paul Arblaster, Mario Infelise, André Belo, Noah Moxham, Carmen Espejo, and Joad Raymond. "European Postal Networks." In News Networks in Early Modern Europe, edited by Noah Moxham and Joad Raymond, 19-63. Leiden: Brill, 2016.

Scott, Joan W. "Gender: A Useful Category of Historical Analysis.” The American Historical Review 91, no. 5 (1986): 1053-1075.

“Evidence of Experience.” Critical Inquiry 17, no.4 (1991), 773-797.

Gender and the Politics of History. New York: Columbia University Press, 1999.

Seaward, Paul. "Hyde, Edward, first earl of Clarendon." Oxford Dictionary of National Biography. 04 Oct. 2008. https://doi.org/10.1093/ref:odnb/14328.

Sperling, Jutta Gisela. Convents and the Body Politic in Late Renaissance Venice. Chicago: Chicago University Press, 2000.

Strasser, Ulrike. "Early Modern Nuns and the Feminist Politics of Religion." The Journal of Religion 84, no. 4 (2004): 529-554.

State of Virginity: Gender, Religion, and Politics in an Early Modern Catholic State. Ann Arbor: University of Michigan Press, 2004.

"The Cloister as Membrane: Recent Convent Histories and the Circulation of People and Ideas." Gender \& History 19, no. 2 (2007): 369-375.

"Clara Hortulana of Embach or How to Suffer Martyrdom in the Cloister." In Female Monasticism in Early Modern Europe, edited by Cordula Van Wyhe, 3957. Burlington VT: Ashgate, 2008. 
Tarbin, Stephanie and Susan Broomhall. "Introduction." In Women, Identities and Communities in Early Modern Europe, edited by Stephanie Tarbin and Susan Broomhall, 1-11. Aldershot: Ashgate, 2008.

Temple, Liam P. "The Mysticism of Augustine Baker, OSB: A

Reconsideration.” Reformation \& Renaissance Review 19, no. 3 (2017): 213-230.

Terpstra, Nicholas. Religious Refugees in the Early Modern World: An Alternative History of the Reformation. Cambridge: Cambridge University Press, 2015.

Van Hyning, Victoria. Convent Autobiography: Early Modern English Nuns in Exile. Oxford: Oxford University Press, 2019.

Walker, Claire. "Combining Martha and Mary: Gender and Work in Seventeenth-Century English Cloisters.” The Sixteenth Century Journal 30, no. 2 (1999): 397-418.

"Prayer, Patronage, and Political Conspiracy: English Nuns and the Restoration." The Historical Journal 43, no. 1 (2000): 1-23.

" "Doe not supose me a well mortifyed Nun dead to the world": Letter-writing in Early Modern English Convents." In Early Modern Women's Letter-Writing, 1450-1700, edited by J. Daybell, 159-76. Basingstoke: Palgrave Macmillan, 2001 .

Gender and Politics in Early Modern Europe: English Convents in France and the Low Countries. New York: Palgrave Macmillan, 2003.

"Loyal and Dutiful Subjects: English Nuns and Stuart Politics." In Women and Politics in Early Modern England, 1450-1700, edited by James Daybell, 228242. Burlington, VT: Ashgate, 2004.

"Spiritual Property: The English Benedictine Nuns of Cambrai and the Dispute over the Baker Manuscripts." In Women, Property and the Letters of the Law in Early Modern England, edited by N.E. Wright, M.W. Ferguson, and A. R. Buck, 237-55. Toronto: University of Toronto Press, 2004.

"Recusants, Daughters and Sisters in Christ: English Nuns and their Communities in the Seventeenth Century." In Women, Identities and Communities in Early Modern Europe, edited by Stephanie Tarbin and Susan Broomhall, 61-76. Aldershot: Ashgate, 2008.

"Securing Souls or Telling Tales? The Politics of Cloistered Life in an English Convent." In Female Monasticism in Early Modern Europe: an Interdisciplinary View, edited by Cordula van Wyhe, 227-244. Burlington, VT: Ashgate, 2008. 
"Crumbs of News: Early Modern English Nuns and Royalist Intelligence Networks." Journal of Medieval and Early Modern Studies 42, no. 3 (2012): 635655.

"Whispering Fama: Talk and Reputation in Early Modern Society." In Fama and Her Sisters: Gossip and Rumour in Early Modern Europe, edited by Heather Kerr and Claire Walker, 9-35. Turnhout, Belgium: Brepols, 2015.

"The Experience of Exile in Early Modern English Convents." Parergon 34, no. 2 (2017): 159-177.

Walker, Claire and Heather Kerr. "Introduction: New Perspectives on Fama." In Fama and Her Sisters: Gossip and Rumour in Early Modern Europe, edited by Heather Kerr and Claire Walker, 1-8. Turnhout, Belgium: Brepols, 2015.

Wall, Alison. "Deference and Defiance in Women's Letters of the Thynne Family: the Rhetoric of Relationships." In Early Modern Women's Letter-Writing, 14501700, edited by James Daybell, 77-93. Basingstoke: Palgrave Macmillan, 2001.

Walsham, Alexandra. "Translating Trent? English Catholicism and the Counter Reformation." Historical Research 78, no. 201 (2005): 288-310.

Warren, Nancy Bradley. The Embodied Word: Female Spiritualities, Contested Orthodoxies, and English Religious Cultures, 1350-1700. Notre Dame: University of Notre Dame Press, 2010.

Waterworth, James. The Canons and Decrees of the Sacred and Ecumenical Council of Trent: Celebrated Under the Sovereign Pontiffs, Paul III., Julius III., and Pius IV. London: Burns and Oates, 1848.

Watkinson, Caroline. "Engaging Nuns: Exiled English Convents and the Politics of Exclusion, 1590-1829.” PhD diss., University of Westminster, 2016. ProQuest Dissertations Publishing.

Welter, Barbara. "The Cult of True Womanhood: 1820-1860.” American Quarterly 18, no. 2 (1966): 151-174.

Wiesner-Hanks, Merry. Convents Confront the Reformation: Catholic and Protestant Nuns in Germany. Milwaukee: Marquette University Press, 1996.

Women and Gender in Early Modern Europe. Second ed. New York: Cambridge University Press, 2000.

Willen, Diane. "Religion and the Construction of the Feminine." In A Companion to Early Modern Women's Writing, edited by Anita Pacheco, 22-39. Oxford: Blackwell, 2002. 
White, Micheline. "Introduction: Women, Religious Communities, Prose Genres, and Textual Production." In English Women, Religion, and Textual Production, 15001625, edited by Micheline White, 1-13. Burlington, VT: Ashgate, 2011.

Wolfe, Heather. "Dame Barbara Constable: Catholic Antiquarian, Advisor, and Closet Missionary." In Catholic Culture in Early Modern England, edited by Ronald Corthell, Frances E. Dolan, and Arthur F. Marotti, 158-188. Notre Dame: University of Notre Dame Press, 2008.

Youings, Joyce. The Dissolution of the Monasteries. London: George Allen and Unwin, 1971.

Zarri, Gabriella. "Sixteenth Century Letters: Typologies and Examples From the Monastic Circuits." In Reading, Interpreting and Historicizing: Letters as Historical Sources, edited by Regina Schlute and Xenia Von Tippelskirch, 39-52. Florence: European University Institute, 2004. 